\title{
Review article: How does glacier discharge affect marine biogeochemistry and primary production in the Arctic?
}

\author{
Mark J. Hopwood ${ }^{1}$, Dustin Carroll ${ }^{2}$, Thorben Dunse ${ }^{3,4}$, Andy Hodson $^{3,5}$, Johnna M. Holding ${ }^{6}$, José L. Iriarte ${ }^{7}$, \\ Sofia Ribeiro $^{8}$, Eric P. Achterberg ${ }^{1}$, Carolina Cantoni ${ }^{9}$, Daniel F. Carlson ${ }^{14}$, Melissa Chierici ${ }^{5,10}$, Jennifer S. Clarke ${ }^{1}$, \\ Stefano Cozzi $^{9}$, Agneta Fransson ${ }^{11}$, Thomas Juul-Pedersen ${ }^{12}$, Mie H. S. Winding ${ }^{12}$, and Lorenz Meire ${ }^{12,13}$ \\ ${ }^{1}$ GEOMAR Helmholtz Centre for Ocean Research Kiel, Kiel, Germany \\ ${ }^{2}$ Moss Landing Marine Laboratories, San José State University, Moss Landing, CA \\ ${ }^{3}$ Western Norway University of Applied Sciences, Sogndal, Norway \\ ${ }^{4}$ The University of Oslo, Oslo, Norway \\ ${ }^{5}$ The University Centre in Svalbard, Longyearbyen, Svalbard \\ ${ }^{6}$ Department of Bioscience, Aarhus University, Silkeborg, Denmark \\ ${ }^{7}$ Instituto de Acuicultura and Centro Dinámica de Ecosistemas Marinos de Altas Latitudes - IDEAL, \\ Universidad Austral de Chile, Puerto Montt, Chile \\ ${ }^{8}$ Geological Survey of Denmark and Greenland, Copenhagen, Denmark \\ ${ }^{9}$ CNR-ISMAR Istituto di Scienze Marine, Trieste, Italy \\ ${ }^{10}$ Institute of Marine Research, Fram Centre, Troms $\varnothing$, Norway \\ ${ }^{11}$ Norwegian Polar Institute, Fram Centre, Troms $\varnothing$, Norway \\ ${ }^{12}$ Greenland Climate Research Centre, Greenland Institute of Natural Resources, Nuuk, Greenland \\ ${ }^{13}$ Royal Netherlands Institute for Sea Research, and Utrecht University, Yerseke, the Netherlands \\ ${ }^{14}$ Institute of Coastal Research, Helmholtz-Zentrum Geesthacht, Centre for Materials and Coastal Research, \\ Geesthacht, Germany
}

Correspondence: Mark J. Hopwood (mhopwood@geomar.de)

Received: 3 June 2019 - Discussion started: 18 June 2019

Revised: 27 January 2020 - Accepted: 27 February 2020 - Published: 24 April 2020

\begin{abstract}
Freshwater discharge from glaciers is increasing across the Arctic in response to anthropogenic climate change, which raises questions about the potential downstream effects in the marine environment. Whilst a combination of long-term monitoring programmes and intensive Arctic field campaigns have improved our knowledge of glacier-ocean interactions in recent years, especially with respect to fjord/ocean circulation, there are extensive knowledge gaps concerning how glaciers affect marine biogeochemistry and productivity. Following two cross-cutting disciplinary International Arctic Science Committee (IASC) workshops addressing the importance of glaciers for the marine ecosystem, here we review the state of the art concerning how freshwater discharge affects the marine environment with a specific focus on marine biogeochemistry and biological productivity. Using a series of Arc-
\end{abstract}

tic case studies (Nuup Kangerlua/Godthåbsfjord, Kongsfjorden, Kangerluarsuup Sermia/Bowdoin Fjord, Young Sound and Sermilik Fjord), the interconnected effects of freshwater discharge on fjord-shelf exchange, nutrient availability, the carbonate system, the carbon cycle and the microbial food web are investigated. Key findings are that whether the effect of glacier discharge on marine primary production is positive or negative is highly dependent on a combination of factors. These include glacier type (marineor land-terminating), fjord-glacier geometry and the limiting resource(s) for phytoplankton growth in a specific spatio-temporal region (light, macronutrients or micronutrients). Arctic glacier fjords therefore often exhibit distinct discharge-productivity relationships, and multiple casestudies must be considered in order to understand the net effects of glacier discharge on Arctic marine ecosystems. 


\section{Introduction}

Annual freshwater discharge volume from glaciers has increased globally in recent decades (Rignot et al., 2013; Bamber et al., 2018; Mouginot et al., 2019) and will continue to do so across most Arctic regions until at least the middle of this century under a Representative Concentration Pathway (RCP) 4.5 climate scenario (Bliss et al., 2014; Huss and Hock, 2018). This increase in discharge (surface runoff and subsurface discharge into the ocean) raises questions about the downstream effects in marine ecosystems, particularly with respect to ecosystem services such as carbon sequestration and fisheries (Meire et al., 2015, 2017; Milner et al., 2017). In order to understand the effect of glaciers on the present-day marine environment and under future climate scenarios, knowledge of the physical and chemical perturbations occurring in the water column as a result of glacier discharge and the structure, function, and resilience of ecosystems within these regions must be synthesized.

Quantifying the magnitude of environmental perturbations from glacial discharge is complicated by the multiple concurrent, and occasionally counteracting, effects that glacial discharge has in the marine environment. For example, ice-rock abrasion means that glacially fed rivers can carry higher sediment loads than temperate rivers (Chu et al., 2009; Overeem et al., 2017). Extensive sediment plumes where glacier discharge first enters the ocean limit light penetration into the water column (Murray et al., 2015; Halbach et al., 2019), and ingestion of glacial flour particles can be hazardous, or even fatal, to zooplankton, krill and benthic fauna (White and Dagg, 1989; Włodarska-Kowalczuk and Pearson, 2004; Arendt et al., 2011; Fuentes et al., 2016). However, these plumes also provide elevated concentrations of inorganic components such as calcium carbonate, which affects seawater alkalinity (Yde et al., 2014; Fransson et al., 2015), and dissolved silicic acid (hereafter $\mathrm{Si}$ ) (Brown et al., 2010; Meire et al., 2016a) and iron (Fe) (Statham et al., 2008; Lippiatt et al., 2010), which can potentially increase marine primary production (Gerringa et al., 2012; Meire et al., 2016a).

The impacts of glacier discharge can also depend upon the spatial and temporal scales investigated (van de Poll et al., 2018). In semi-enclosed Arctic coastal regions and fjord systems, summertime discharge typically produces strong, nearsurface stratification. This results in a shallow, nutrient-poor layer which reduces primary production and drives phytoplankton biomass deeper in the water column (Rysgaard et al., 1999; Juul-Pedersen et al., 2015; Meire et al., 2017). On broader scales across continental shelves, freshening can similarly reduce vertical nutrient supply throughout summer (Coupel et al., 2015) but may also impede the breakdown of stratification in autumn, thereby extending the phytoplankton growing season (Oliver et al., 2018). Key research questions are how and on what spatial and temporal timescales these different effects interact to enhance, or reduce, marine primary production. Using a synthesis of field studies from glacier catchments with different characteristics (Fig. 1), we provide answers to three questions arising from two interdisciplinary workshops on the importance of Arctic glaciers for the marine ecosystem under the umbrella of the International Arctic Science Committee (IASC).

1. Where and when does glacial freshwater discharge promote or reduce marine primary production?

2. How does spatio-temporal variability in glacial discharge affect marine primary production?

3. How far-reaching are the effects of glacial discharge on marine biogeochemistry?

\section{Fjords as critical zones for glacier-ocean interactions}

In the Arctic and sub-Antarctic, most glacial discharge enters the ocean through fjord systems (Iriarte et al., 2014; Straneo and Cenedese, 2015). The strong lateral gradients and seasonal changes in environmental conditions associated with glacial discharge in these coastal environments differentiate these ecosystems from offshore systems (Arendt et al., 2013; Lydersen et al., 2014; Krawczyk et al., 2018). Fjords can be efficient sinks for organic carbon (Smith et al., 2015) and $\mathrm{CO}_{2}$ (Rysgaard et al., 2012; Fransson et al., 2015), sustain locally important fisheries (Meire et al., 2017) and are critical zones for deep mixing which dictate how glacially modified waters are exchanged with the coastal ocean (Mortensen et al., 2014; Straneo and Cenedese, 2015; Beaird et al., 2018). Fjord-scale processes therefore comprise an integral part of all questions concerning how glacial discharge affects Arctic coastal primary production (Arimitsu et al., 2012; Renner et al., 2012; Meire et al., 2017).

Fjords act as highly stratified estuaries and provide a pathway for the exchange of heat, salt, and nutrients between near-glacier waters and adjacent coastal regions (Mortensen et al., 2014, 2018; Straneo and Cenedese, 2015). In deep fjords, such as those around much of the periphery of Greenland, warm, saline water is typically found at depth (> $200 \mathrm{~m}$ ), overlaid by cold, fresher water and, during summer, a thin layer ( $\sim 50 \mathrm{~m}$ or less) of relatively warm near-surface water (Straneo et al., 2012). The injection of freshwater into fjords from subglacial discharge (Xu et al., 2012; Carroll et al., 2015) and terminus (Slater et al., 2018) and iceberg melt (Moon et al., 2018) can drive substantial buoyancy-driven flows in the fjord (Carroll et al., 2015, 2017; Jackson et al., 2017), which amplify exchange with the shelf system as well as submarine melting and the calving rates of glacier termini. To date, such modifications to circulation and exchange between glacier fjords and shelf waters have primarily been studied in terms of their effects on ocean physics and melting at glacier termini, yet they also have profound impacts on marine productivity (Meire et al., 2016a; Kanna et al., 2018; Torsvik et al., 2019). 


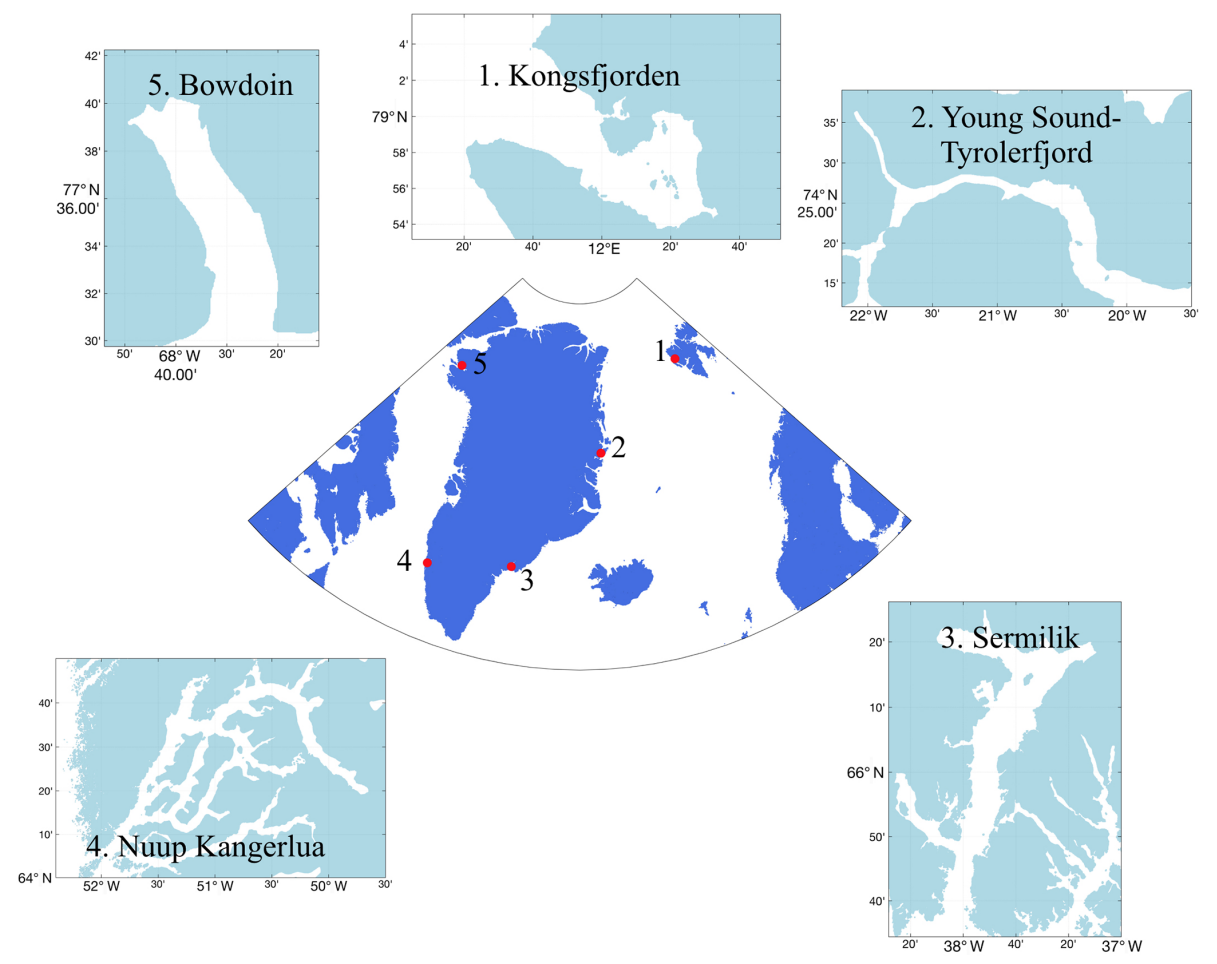

Figure 1. Locations of five key Arctic field sites, where extensive work bridging the glacier and marine domains has been conducted, discussed herein in order to advance understanding of glacier-ocean interactions. 1: Kongsfjorden (Svalbard); 2: Young Sound (E Greenland); 3: Sermilik (SE Greenland); 4: Nuup Kangerlua/Godthåbsfjord (SW Greenland); 5: Bowdoin Fjord/Kangerluarsuup Sermia (NW Greenland).

While renewal of fjord waters from buoyancy-driven processes is mainly thought to occur over seasonal to sub-annual timescales (Gladish et al., 2014; Mortensen et al., 2014; Carroll et al., 2017), energetic shelf forcing (i.e. from coastal/katabatic winds and coastally trapped waves) can result in rapid exchange over synoptic timescales (Straneo et al., 2010; Jackson et al., 2014; Moffat, 2014) and similarly also affect marine productivity (Meire et al., 2016b). Katabatic winds are common features of glaciated fjords. Down-fjord wind events facilitate the removal of low-salinity surface waters and ice from glacier fjords, as well as the inflow of warmer, saline waters at depth (Johnson et al., 2011). The frequency, direction and intensity of wind events throughout the year thus adds further complexity to the effect that fjord geometry has on fjord-shelf exchange processes (Cushman-Roisin et al., 1994; Spall et al., 2017). Topographic features such as sills and lateral constrictions can exert a strong control on fjord-shelf exchange (Gladish et al., 2014; Carroll et al., 2017, 2018). Ultimately, circulation can thereby vary considerably depending on fjord geometry and the relative contributions from buoyancy, wind and shelf forcing (Straneo and Cenedese, 2015; Jackson et al., 2018). Some variability in the spatial patterns of primary production is therefore expected between Arctic glacier fjord systems as differences in geometry and forcing affect exchange with the shelf and water column structure.
These changes affect the availability of the resources which constrain local primary production (Meire et al., 2016b; Arimitsu et al., 2016; Calleja et al., 2017).

\begin{tabular}{|c|}
\hline Nuup Kangerlua / Godthåbsfjord (SW Greenland) $64^{\circ} \mathrm{N}, 051^{\circ} \mathrm{W}$ \\
\hline $\begin{array}{l}\text { Nuup Kangerlua (also known as Godthåbsfjord) is a large glacier fjord system ( } \sim 190 \mathrm{~km} \\
\text { long, } 4-8 \mathrm{~km} \text { wide and up to } 625 \mathrm{~m} \text { deep). The fjord hosts six different glaciers (three land- } \\
\text { terminating and three marine-terminating), including the marine-terminating glaciers } \\
\text { Kangiata Nunaata Sermia, Akugdlerssup Sermia, and Narsap Sermia. The shallowest sill } \\
\text { within the fjord is at } \sim 170 \mathrm{~m} \text { depth (Mortensen et al., 2011). Nuup Kangerlua is one of } \\
\text { few well-studied Greenland fjord systems, due to extensive work conducted by the } \\
\text { Greenland Institute of Natural Resources. A data portal is available containing monthly } \\
\text { fjord data through the Greenland Ecosystem Monitoring Programme (GEM; http://g-e- } \\
\text { m.dk). }\end{array}$ \\
\hline
\end{tabular}

Fjord-shelf processes also contribute to the exchange of active cells and microbial species' resting stages, thus preconditioning primary production prior to the onset of the growth season (Krawczyk et al., 2015, 2018). Protists (unicellular eukaryotes) are the main marine primary producers in the Arctic. This highly specialized and diverse group includes species that are ice-associated (sympagic) and/or pelagic. Many protists in fjords and coastal areas of the Arctic maintain diverse seed banks of resting stages, which promotes the resilience and adaptability of species on timescales from seasons to decades (Ellegaard and Ribeiro, 2018). Yet seawater inflow into fjords can still change the dominant species within a single season. In Nuup Kangerlua (Godthåb- 


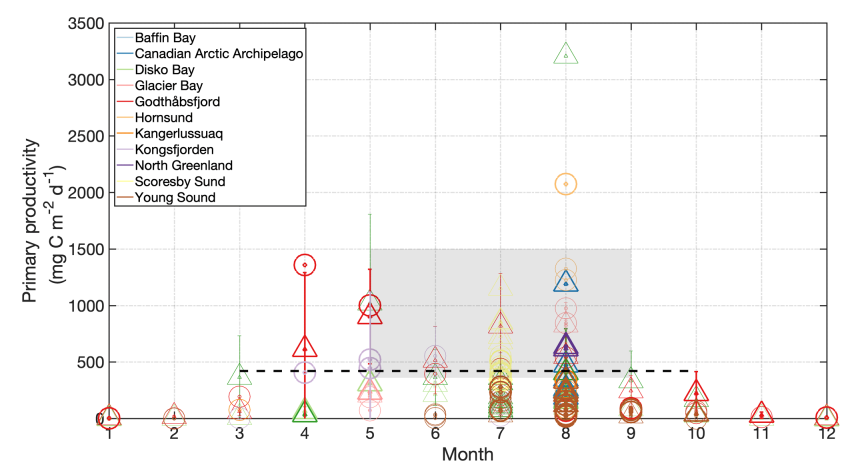

Figure 2. Primary production for Arctic glacier fjord systems including Disko Bay (Andersen, 1977; Nielsen and Hansen, 1995; Jensen et al., 1999; Nielsen, 1999; Levinsen and Nielsen, 2002), Godthåbsfjord (Juul-Pedersen et al., 2015; Meire et al., 2017), Kangerlussuaq (Lund-Hansen et al., 2018), Kongsfjorden (Hop et al., 2002; Iversen and Seuthe, 2011; Hodal et al., 2012; van de Poll et al., 2018), Nordvestfjord/Scoresby Sund (Seifert et al., 2019), Hornsund (Smoła et al., 2017), Young Sound (Rysgaard et al., 1999; Meire et al., 2017; Holding et al., 2019), the Canadian Arctic Archipelago (Harrison et al., 1982) and Glacier Bay (Reisdorph and Mathis, 2015). Circles represent glacier fjords, triangles are sites beyond glacier fjords and bold markers are $<80 \mathrm{~km}$ from a marine-terminating glacier. Error bars are standard deviations for stations where multiple measurements were made at the same station. Dashed line is the pan-Arctic mean primary production (March-September). Shaded area is the pan-Arctic shelf range of primary production for May-August (Pabi et al., 2008).

sfjord), the spring phytoplankton bloom is typically dominated by Fragilariopsis spp. diatoms and Phaeocystis spp. haptophytes. Unusually prolonged coastal seawater inflow in spring 2009 led to the mass occurrence of chain-forming Thalassiosira spp. diatoms and the complete absence of the normally abundant Phaeocystis spp. (Krawczyk et al., 2015) - a pattern which has been found elsewhere in the Arctic, including Kongsfjorden (Hegseth and Tverberg, 2013).

\section{Pelagic primary production in Arctic glacier fjords}

Key factors controlling rates of primary production across Arctic marine environments are light availability, nutrient availability and grazing (Nielsen, 1999; Taylor et al., 2013; Arrigo and van Dijken, 2015; Tremblay et al., 2015). Seasonal changes in the availability of bioessential resources, the structure of the water column and the feeding patterns of zooplankton thereby interact to produce distinct bloom periods of high primary production shouldered by periods of low primary production. In glacier fjords, strong lateral and vertical gradients in some, or all, of these factors create a far more dynamic situation for primary producers than in the open ocean (Etherington and Hooge, 2007; Arendt et al., 2010; Murray et al., 2015).
Large inter- and intra-fjord differences in primary production are demonstrated by field observations around the Arctic which show that glacier fjords range considerably in productivity from very low ( $<40 \mathrm{mg} \mathrm{C} \mathrm{m}^{-2} \mathrm{~d}^{-1}$ ) to moderately productive systems ( $>500 \mathrm{mg} \mathrm{C} \mathrm{m}^{-2} \mathrm{~d}^{-1}$ ) during the meltwater season (e.g. Jensen et al., 1999; Rysgaard et al., 1999; Hop et al., 2002; Meire et al., 2017). For comparison, the pan-Arctic basin exhibits a mean production of $420 \pm 26 \mathrm{mg} \mathrm{C} \mathrm{m}^{-2} \mathrm{~d}^{-1}$ (mean March-September 1998-2006) (Pabi et al., 2008), which has increased across most regions in recent decades due to reduced summertime sea-ice coverage (Arrigo and van Dijken, 2015), and summertime (May-August) Arctic shelf environments exhibit a range of $360-1500 \mathrm{mg} \mathrm{C} \mathrm{m}^{-2} \mathrm{~d}^{-1}$ (Pabi et al., 2008). So is it possible to generalize how productive Arctic glacier fjords are?

Extensive measurements of primary production throughout the growth season in glacier fjords are only available for Godthåbsfjord (Juul-Pedersen et al., 2015; Meire et al., 2017), Young Sound (Rysgaard et al., 1999; Meire et al., 2017; Holding et al., 2019), Glacier Bay (Alaska, Reisdorph and Mathis, 2015), Hornsund (Svalbard, Smoła et al., 2017) and Kongsfjorden (Iversen and Seuthe, 2011; van de Poll et al., 2018). Observations elsewhere are sparse and typically limited to summertime-only data. Generalizing across multiple Arctic glacier fjord systems therefore becomes challenging due to the paucity of data and the different geographic and seasonal context of individual primary production data points (Fig. 2). Furthermore there are potentially some methodological implications when comparing direct measurements of primary production using ${ }^{14} \mathrm{C}$ uptake (e.g. Holding et al., 2019), with estimates derived from changes in water column macronutrient (e.g. Seifert et al., 2019) or dissolved inorganic carbon (e.g. Reisdorph and Mathis, 2015) inventories.

Nevertheless, some quantitative comparison can be made if we confine discussion to months where a meltwater signal may be evident in most glaciated regions (July-September). All available data for Arctic glaciated regions can then be pooled according to whether it refers to primary production within a glacier fjord and whether or not it could plausibly be influenced by the presence of a marine-terminating glacier (see Sect. 5). For the purposes of defining the spatial extent of individual glacier fjords, we consider broad bay areas such as the lower and central parts of Glacier Bay (Etherington and Hooge, 2007; Reisdorph and Mathis, 2015), Scoresby Sund (Scoresby Sound in English; Seifert et al., 2019) and Disko Bay (Jensen et al., 1999; Nielsen, 1999) to be beyond the scale of the associated glacier fjords on the basis of the oceanographic interpretation presented in the respective studies. Defining the potential spatial influence of marineterminating glaciers is more challenging. Using observations from Godthåbsfjord, where primary production is found to be affected on a scale of 30-80 km down-fjord from the marineterminating glaciers therein (Meire et al., 2017), we define 
a region $<80 \mathrm{~km}$ downstream of calving fronts as being potentially influenced by marine-terminating glaciers.

Four exclusive categories of primary production data result (Table 1). Primary production for group I is significantly higher than any other group, and group II is also significantly higher than group IV $(p<0.025)$. Primary production is higher in regions designated as having a potential marineterminating glacier influence. On the contrary, other nearglacier regions (i.e. with land-terminating glaciers) seem to have low summertime primary productivity, irrespective of how mean Arctic primary production is defined (Table 1). What processes could lead to such differences? In the next sections of this review we discuss the biogeochemical features of glacier-affected marine regions that could potentially explain such trends if they do not simply reflect data deficiency.

\section{Effects of glacial discharge on marine resource availability}

One of the most direct mechanisms via which glacial discharge affects downstream marine primary production is by altering the availability of light, macronutrients (such as nitrate, $\mathrm{NO}_{3}$; phosphate, $\mathrm{PO}_{4}$; and silicic acid, $\mathrm{Si}$ ) and/or micronutrients (such as iron and manganese) in the ocean. The chemical composition of glacial discharge is now relatively well constrained, especially around Greenland (Yde et al., 2014; Meire et al., 2016a; Stevenson et al., 2017), Alaska (Hood and Berner, 2009; Schroth et al., 2011) and Svalbard (Hodson et al., 2004, 2016). Whilst high particle loads (Chu et al., 2012; Overeem et al., 2017) and Si are often associated with glacially modified waters (Fig. 3a) around the Arctic (Brown et al., 2010; Meire et al., 2016a), the concentrations of all macronutrients in glacial discharge (Meire et al., 2016a) are relatively low and similar to those of coastal seawater (Fig. 3a, b and c).

Macronutrient concentrations in Arctic rivers can be higher than in glacier discharge (Holmes et al., 2011) (Fig. 3d, e and f). Nevertheless, river and glacier meltwater alike do not significantly increase the concentration of $\mathrm{PO}_{4}$ in Arctic coastal waters (Fig. 3c and f). River water is, relatively, a much more important source of $\mathrm{NO}_{3}$ (Cauwet and Sidorov, 1996; Emmerton et al., 2008; Hessen et al., 2010), and in river estuaries this nutrient can show a sharp decline with increasing salinity due to both mixing and biological uptake (Fig. 3e). Patterns in Si are more variable (Cauwet and Sidorov, 1996; Emmerton et al., 2008; Hessen et al., 2010). Dissolved Si concentration at low salinity is higher in rivers than in glacier discharge (Fig. 3a and d), yet a variety of estuarine behaviours are observed across the Arctic. Peak dissolved Si occurs at a varying salinity, due to the opposing effects of Si release from particles and dissolved Si uptake by diatoms (Fig. 3d).

\section{Kongsfjorden (W Svalbard) $79^{\circ} \mathrm{N}, 012^{\circ} \mathrm{E}$}

Kongsfjorden is a small Arctic fjord on the west coast of Svalbard notable for pronounced sediment plumes originating from multiple proglacial streams and several shallow marine-terminating glaciers. There is no sill at the fjord entrance, and thus warm Atlantic water can be found throughout the fjord in summer (Hop et al., 2002). The major marine-terminating glaciers at the fjord head (Kongsvegen and Kronebreen) have been retreating since before monitoring began (Liestøl, 1988; Svendsen et al., 2002) and are anticipated to transition to land-terminating systems in the coming decades (Torsvik et al., 2019). Research within the fjord is logged in the RIS (Research in Svalbard; https://researchinsvalbard.no) online system.

A notable feature of glacial freshwater outflows into the ocean is the high turbidity that occurs in most Arctic glacier fjords. High turbidity in surface waters within glacier fjords arises from the high sediment transport in these drainage systems (Chu et al., 2012), from iceberg melting and also from the resuspension of fine sediments (Azetsu-Scott and Syvitski, 1999; Zajączkowski and Włodarska-Kowalczuk, 2007; Stevens et al., 2016). The generally high sediment load of glacially derived freshwater is evident around Greenland, which is the origin of $\sim 1 \%$ of annual freshwater discharge into the ocean yet $7 \%-9 \%$ of the annual fluvial sediment load (Overeem et al., 2017). Sediment load is however spatially and temporally variable, leading to pronounced interand intra-catchment differences (Murray et al., 2015). For example, satellite-derived estimates of sediment load for 160 Greenlandic glacier outflows suggest a median sediment load of $992 \mathrm{mg} \mathrm{L}^{-1}$, but some catchments exhibit $>3000 \mathrm{mg} \mathrm{L}^{-1}$ (Overeem et al., 2017). Furthermore it is suggested that $>$ $25 \%$ of the total annual sediment load is released in a single outflow (from the Sermeq glacier) (Overeem et al., 2017).

The extent to which high turbidity in glacier outflows limits light availability in downstream marine environments is therefore highly variable between catchments and with distance from glacier outflows (Murray et al., 2015; Mascarenhas and Zielinski, 2019). The occurrence, and effects, of subsurface turbidity peaks close to glaciers is less well studied. Subsurface turbidity features may be even more spatially and temporally variable than their surface counterparts (Stevens et al., 2016; Kanna et al., 2018; Moskalik et al., 2018). In general, a spatial expansion of near-surface turbid plumes is expected with increasing glacier discharge, but this trend is not always evident at the catchment scale (Chu et al., 2009, 2012; Hudson et al., 2014). Furthermore, with longterm glacier retreat, the sediment load in discharge at the coastline is generally expected to decline as proglacial lakes are efficient sediment traps (Bullard, 2013; Normandeau et al., 2019).

In addition to high turbidity, the low concentration of macronutrients in glacier discharge relative to saline waters is evidenced by the estuarine mixing diagram in Kongsfjorden (Fig. 3) and confirmed by extensive measurements of freshwater nutrient concentrations (e.g. Hodson et al., 2004, 2005). For $\mathrm{PO}_{4}$ (Fig. 3c), there is a slight increase in concentration with salinity (i.e. discharge dilutes the nutrient concentration in the fjord). For $\mathrm{NO}_{3}$, discharge slightly increases 
Table 1. July-September marine primary production (PP) data from studies conducted in glaciated Arctic regions. PP data points are categorised into four groups according to whether or not they are within $80 \mathrm{~km}$ of a marine-terminating glacier and whether or not they are within a glacier fjord. Data sources as per Fig. 2. $n$ is the number of data points; where studies report primary production measurements at the same station for the same month at multiple time points (e.g. Juul-Pedersen et al., 2015) a single mean is used in the data compilation (i.e. $n=1$ irrespective of the historical extent of the time series).

\begin{tabular}{lccl}
\hline Category & $\begin{array}{c}\text { Mean PP } \\
( \pm \text { standard deviation }) \\
\mathrm{mg} \mathrm{C} \mathrm{m}^{-2} \mathrm{~d}^{-1}\end{array}$ & $n$ & Data from \\
\hline $\begin{array}{l}\text { (I) Marine-terminating glacier } \\
\text { influence, non-fjord }\end{array}$ & $847 \pm 852$ & $\begin{array}{l}\text { Disko Bay, Scoresby Sund, Glacier } \\
\text { Bay, North Greenland, Canadian Arctic } \\
\text { Archipelago }\end{array}$ \\
\hline $\begin{array}{l}\text { (II) Marine-terminating glacier } \\
\text { influence, glacier fjord }\end{array}$ & $480 \pm 403$ & 33 & $\begin{array}{l}\text { Godthåbsfjord, Kongsfjorden, Scoresby } \\
\text { Sund, Glacier Bay, Hornsund, }\end{array}$ \\
\hline $\begin{array}{l}\text { (III) No marine-terminating glacier } \\
\text { influence, non-fjord }\end{array}$ & $304 \pm 261$ & 42 & $\begin{array}{l}\text { Godthåbsfjord, Young Sound, Scoresby } \\
\text { Sund, Disko Bay, Canadian Arctic } \\
\text { Archipelago }\end{array}$ \\
\hline $\begin{array}{l}\text { (IV) No marine-terminating glacier } \\
\text { influence, glacier fjord }\end{array}$ & $125 \pm 102$ & 35 & $\begin{array}{l}\text { Godthåbsfjord, Young Sound, Kangerlus- } \\
\text { suaq, Disko Bay }\end{array}$ \\
\hline
\end{tabular}

(a)

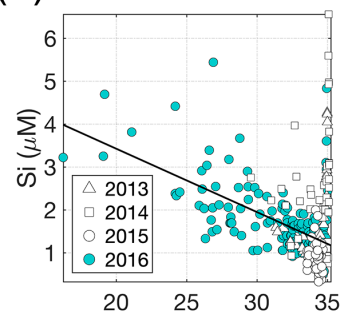

(d)

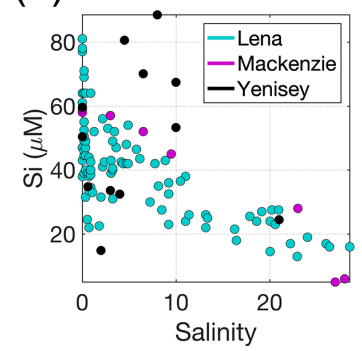

(b)

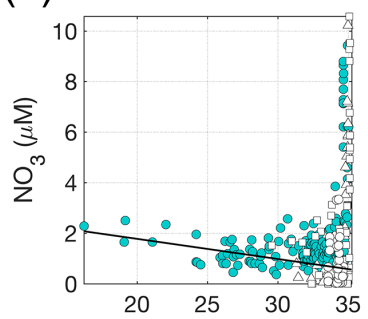

(e)

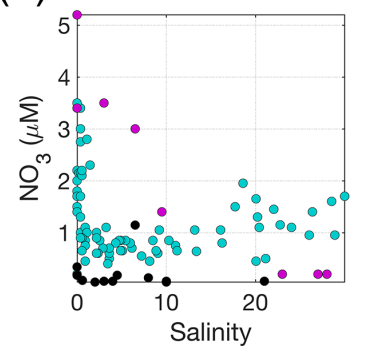

(c)

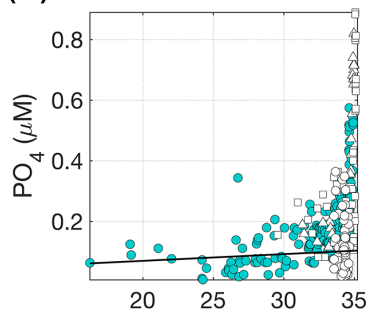

(f)

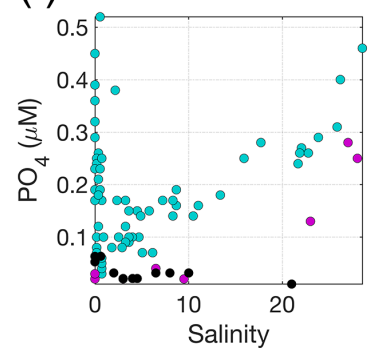

Figure 3. (a) $\mathrm{Si}$, (b) $\mathrm{NO}_{3}$ and (c) $\mathrm{PO}_{4}$ distributions across the measured salinity gradient in Kongsfjorden in summer 2013 (Fransson et al., 2016), 2014 (Fransson et al., 2016), 2015 (van de Poll et al., 2018) and 2016 (Cantoni et al., 2019). Full depth data are shown, with a linear regression (black line) for glacially modified waters $(S<34.2)$ during summer 2016. The position of stations varies between the datasets, with the 2016 data providing the broadest coverage of the inner fjord. Linear regression details are shown in Table S1 in the Supplement. (d) $\mathrm{Si}$, (e) $\mathrm{NO}_{3}$ and (f) $\mathrm{PO}_{4}$ distributions in surface waters of three major Arctic river estuaries: the Lena, Mackenzie and Yenisey (Cauwet and Sidorov, 1996; Emmerton et al., 2008; Hessen et al., 2010). Note the different $y$ - and $x$-axis scales.

the concentration in the upper-mixed layer (Fig. 3b). For Si, a steady decline in Si with increasing salinity (Fig. 3a) is consistent with a discharge-associated Si supply (Brown et al., 2010; Arimitsu et al., 2016; Meire et al., 2016a). The spatial distribution of data for summer 2013-2016 is similar and representative of summertime conditions in the fjord (Hop et al., 2002).
Whilst dissolved macronutrient concentrations in glacial discharge are relatively low, a characteristic of glaciated catchments is extremely high particulate Fe concentrations. High Fe concentrations arise both directly from glacier discharge (Bhatia et al., 2013a; Hawkings et al., 2014) and also from resuspension of glacially derived sediments throughout the year (Markussen et al., 2016; Crusius et al., 2017). Total 
dissolvable $\mathrm{Fe}$ (TdFe) concentrations within Godthåbsfjord are high in all available datasets (May 2014, August 2014 and July 2015) and strongly correlated with turbidity (linear regression: $R^{2}=0.88, R^{2}=0.56$ and $R^{2}=0.88$, respectively, Hopwood et al., 2016, 2018). A critical question in oceanography, in both the Arctic and Antarctic, is to what extent this large pool of particulate Fe is transferred into open-ocean environments and thus potentially able to affect marine primary production in Fe-limited offshore regions (Gerringa et al., 2012; Arrigo et al., 2017; Schlosser et al., 2018). The mechanisms that promote transfer of particulate Fe into bioavailable dissolved phases, such as ligand-mediated dissolution (Thuroczy et al., 2012) and biological activity (Schmidt et al., 2011), and the scavenging processes that return dissolved $\mathrm{Fe}$ to the particulate phase are both poorly characterized (Tagliabue et al., 2016).

Fe profiles around the Arctic show strong spatial variability in $\mathrm{TdFe}$ concentrations, ranging from unusually high concentrations of up to $20 \mu \mathrm{M}$ found intermittently close to turbid glacial outflows (Zhang et al., 2015; Markussen et al., 2016; Hopwood et al., 2018) to generally low nanomolar concentrations at the interface between shelf and fjord waters (Zhang et al., 2015; Crusius et al., 2017; Cape et al., 2019). An interesting feature of some of these profiles around Greenland is the presence of peak Fe at $\sim 50 \mathrm{~m}$ depth, perhaps suggesting that much of the Fe transport away from glaciers may occur in subsurface turbid glacially modified waters (Hopwood et al., 2018; Cape et al., 2019). The spatial extent of $\mathrm{Fe}$ enrichment downstream of glaciers around the Arctic is still uncertain, but there is evidence of global variability downstream of glaciers on the scale of 10100 km (Gerringa et al., 2012; Annett et al., 2017; Crusius et al., 2017).

\subsection{Non-conservative mixing processes for $\mathrm{Fe}$ and $\mathrm{Si}$}

A key reason for uncertainty in the fate of glacially derived $\mathrm{Fe}$ is the non-conservative behaviour of dissolved Fe in saline waters. In the absence of biological processes (i.e. nutrient assimilation and remineralization), $\mathrm{NO}_{3}$ is expected to exhibit conservative behaviour across estuarine salinity gradients (i.e. the concentration at any salinity is a linear function of mixing between fresh and saline waters). For Fe, however, a classic non-conservative estuarine behaviour occurs due to the removal of dissolved $\mathrm{Fe}\left(\mathrm{DFe}^{1}\right)$ as it flocculates and is absorbed onto particle surfaces more readily at higher salinity and pH (Boyle et al., 1977). Dissolved Fe concentrations almost invariably exhibit strong (typically $\sim 90 \%$ ) non-conservative removal across estuarine salinity gradients (Boyle et al., 1977; Sholkovitz et al., 1978), and glaciated catchments appear to be no exception to this rule (Lippiatt et al., 2010). Dissolved Fe in Godthåbsfjord exhibits a re-

\footnotetext{
${ }^{1}$ For consistency, dissolved $\mathrm{Fe}$ is defined throughout operationally as $<0.2 \mu \mathrm{m}$ and is therefore inclusive of ionic, complexed and colloidal species.
}

moval of $>80 \%$ DFe between salinities of 0-30 (Hopwood et al., 2016), and similar losses of approximately $98 \%$ for Kongsfjorden and $85 \%$ for the Copper river/estuary (Gulf of Alaska) system have been reported (Schroth et al., 2014; Zhang et al., 2015).

Conversely, Si can be released from particulate phases during estuarine mixing, resulting in non-conservative addition to dissolved Si concentrations (Windom et al., 1991), although salinity-Si relationships vary between different estuaries due to different extents of Si release from labile particulates and Si uptake by diatoms (e.g. Fig. 3d). Where evident, this release of dissolved Si typically occurs at low salinities (Cauwet and Sidorov, 1996; Emmerton et al., 2008; Hessen et al., 2010), with the behaviour of Si being more conservative at higher salinities and in estuaries where pronounced drawdown by diatoms is not evident (e.g. Brown et al., 2010). Estimating release of particulate Si from Kongsfjorden data (Fig. 3c) as the additional dissolved Si present above the conservative mixing line for runoff mixing with unmodified saline water that is entering the fjord (via linear regression) suggests a Si enrichment of $13 \% \pm 2 \%$ (Fig. 3a). This is broadly consistent with the $6 \%-53 \%$ range reported for estuarine gradients evident in some temperate estuaries (Windom et al., 1991). Conversely, Hawkings et al. (2017) suggest a far greater dissolution downstream of Leverett Glacier, equivalent to a $70 \%-800 \% \mathrm{Si}$ enrichment, and thus propose that the role of glaciers in the marine Si cycle has been underestimated. Given that such dissolution is substantially above the range observed in any other Arctic estuary, the apparent cause is worth further consideration.

\begin{tabular}{l} 
Bowdoin Fjord (NW Greenland) $78^{\circ} \mathbf{N}, 069^{\circ} \mathbf{W}$ \\
$\begin{array}{l}\text { Kangerluarsuup Sermia, also known as Bowdoin Fjord, is one of few glacier-fjord } \\
\text { systems where biogeochemical and physical data are available in northern Greenland } \\
\text { (Jouvet et al., 2018; Kanna et al., 2018). Bowdoin glacier, a small marine-terminating } \\
\text { glacier at the fjord head, and four smaller land-terminating glaciers draining small ice } \\
\text { caps isolated from the Greenland Ice Sheet, drain into the fjord, which is typically } \\
\text { subject to sea-ice cover until July. The fjord is } \sim 20 \mathrm{~km} \text { long; the terminus of Bowdoin } \\
\text { glacier is } \sim 3 \mathrm{~km} \text { wide. }\end{array}$ \\
\hline
\end{tabular}

The general distribution of Si in surface waters for Kongsfjorden (Fransson et al., 2016), Godthåbsfjord (Meire et al., 2016a), Bowdoin Fjord (Kanna et al., 2018), Sermilik (Cape et al., 2019) and along the Gulf of Alaska (Brown et al., 2010) is similar; Si shows pseudo-conservative behaviour declining with increasing salinity in surface waters. The limited reported number of zero-salinity, or very low salinity, endmembers for Godthåbsfjord and Bowdoin are significantly below the linear regression derived from surface nutrient and salinity data (Fig. 4). In addition to some dissolution of particulate $\mathrm{Si}$, another likely reason for this is the limitation of individual zero-salinity measurements in dynamic fjord systems where different discharge outflows have different nutrient concentrations (Kanna et al., 2018), especially given that subglacial discharge is not directly characterized in either location (Meire et al., 2016a; Kanna et al., 2018). As 


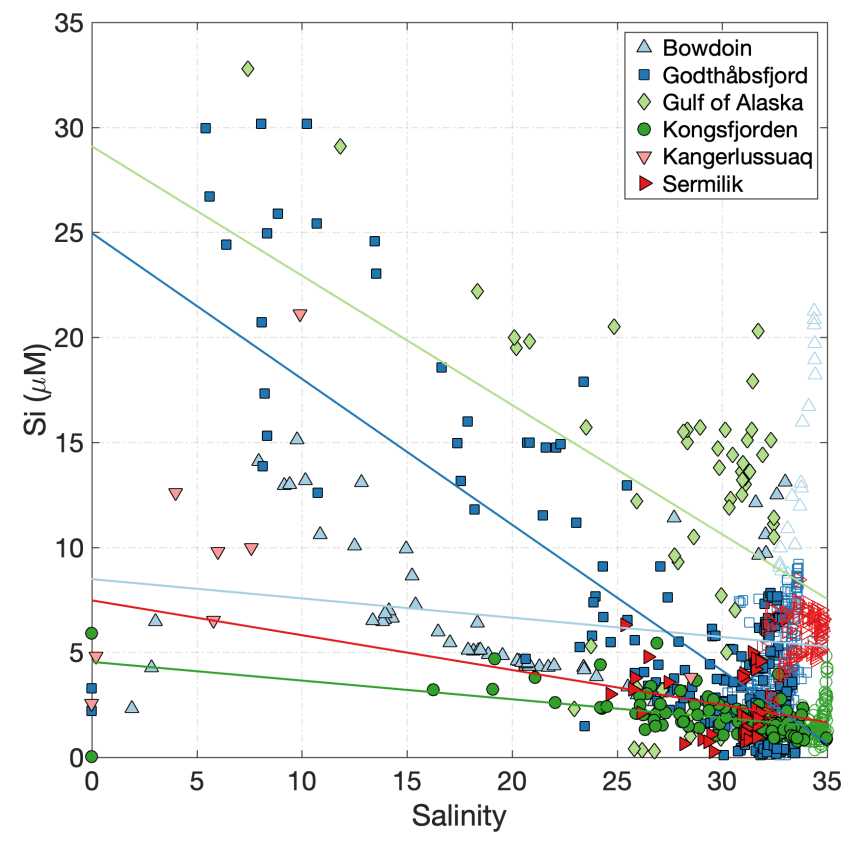

Figure 4. Dissolved Si distribution vs. salinity for glaciated Arctic catchments. Data are from Bowdoin Fjord (Kanna et al., 2018), Kongsfjorden (Fransson et al., 2016; van de Poll et al., 2018), Sermilik Fjord (Cape et al., 2019), Kangerlussuaq (Hawkings et al., 2017; Lund-Hansen et al., 2018), Godthåbsfjord (Hopwood et al., 2016; Meire et al., 2016b), and the Gulf of Alaska (Brown et al., 2010). Linear regressions are shown for large surface datasets only. Linear regression details are shown in Table S1. Closed markers indicate surface data ( $<20 \mathrm{~m}$ depth), and open markers indicate subsurface data.

demonstrated by the two different zero-salinity $\mathrm{Si}$ endmembers in Kongsfjorden (iceberg melt of $\sim 0.03 \mu \mathrm{M}$ and surface runoff of $\sim 5.9 \mu \mathrm{M}$ ), pronounced deviations in nutrient content arise from mixing between various freshwater endmembers (surface runoff, ice melt and subglacial discharge). For example, total freshwater input into Godthåbsfjord is $70 \%-$ $80 \%$ liquid, with this component consisting of $64 \%$ ice sheet runoff, $31 \%$ land runoff, and $5 \%$ net precipitation (Langen et al., 2015) and being subject to additional inputs from iceberg melt along the fjord $(\sim 70 \%$ of calved ice also melts within the inner fjord, Bendtsen et al., 2015).

In a marine context at broad scales, a single freshwater endmember that integrates the net contribution of all freshwater sources can be defined. This endmember includes iceberg melt, groundwater discharge, surface and subsurface glacier discharge, and (depending on location) sea-ice melt, which are challenging to distinguish in coastal waters (Benetti et al., 2019). Close to glaciers, it may be possible to observe distinct freshwater signatures in different water column layers and distinguish chemical signatures in water masses containing subglacial discharge from those containing primarily surface runoff and iceberg melt (e.g. in Godthåbsfjord, Meire et al., 2016a; and Sermilik, Beaird et al., 2018), but this is often challenging due to mixing and overlap between different sources. Back-calculating the integrated freshwater endmember (e.g. from regression, Fig. 4) can potentially resolve the difficulty in accounting for datadeficient freshwater components and poorly characterized estuarine processes. As often noted in field studies, there is a general bias towards sampling of supraglacial meltwater and runoff in proglacial environments and a complete absence of chemical data for subglacial discharge emerging from large marine-terminating glaciers (e.g. Kanna et al., 2018).

Macronutrient distributions in Bowdoin, Godthåbsfjord and Sermilik unambiguously show that the primary macronutrient supply to surface waters associated with glacier discharge originates from mixing rather than from freshwater addition (Meire et al., 2016a; Kanna et al., 2018; Cape et al., 2019), which emphasizes the need to consider fjord inflow/outflow dynamics in order to interpret nutrient distributions. The apparently anomalous extent of Si dissolution downstream of Leverett Glacier (Hawkings et al., 2017) may therefore largely reflect underestimation of both the saline (assumed to be negligible) and freshwater endmembers rather than unusually prolific particulate $\mathrm{Si}$ dissolution. In any case, measured Si concentrations in the Kangerlussuaq region are within the range of other Arctic glacier estuaries (Fig. 4), making it challenging to support the hypothesis that glacial contributions to the Si cycle have been underestimated elsewhere (see also Tables 2 and 3).

\subsection{Deriving glacier-ocean fluxes}

In the discussion of macronutrients herein we have focused on the availability of the bioavailable species (e.g. $\mathrm{PO}_{4}, \mathrm{NO}_{3}$ and silicic acid) that control seasonal trends in inter-annual marine primary production (Juul-Pedersen et al., 2015; van de Poll et al., 2018; Holding et al., 2019). It should be noted that the total elemental fluxes (i.e. nitrogen, phosphorus and silicon) associated with lithogenic particles are invariably higher than the associated macronutrients (Wadham et al., 2019), particularly for phosphorus (Hawkings et al., 2016) and silicon (Hawkings et al., 2017). Lithogenic particles are however not bioavailable, although they may to some extent be bioaccessible, depending on the temporal and spatial scale involved. This is especially the case for the poorly quantified fraction of lithogenic particles that escapes sedimentation in inner-fjord environments, either directly or via resuspension of shallow sediments (Markussen et al., 2016; Hendry et al., 2019). It is hypothesized that lithogenic particle inputs from glaciers therefore have a positive influence on Arctic marine primary production (Wadham et al., 2019), yet field data to support this hypothesis are lacking. A pan-Arctic synthesis of all available primary production data for glaciated regions (Fig. 2 and Table 1), spatial patterns in productivity along the west Greenland coastline (Meire et al., 2017), population responses in glacier fjords across multiple taxonomic groups (Cauvy-Fraunié and Dangles, 2019) and sedimentary 
records from Kongsfjorden (Kumar et al., 2018) consistently suggest that glaciers, or specifically increasing volumes of glacier discharge, have a net negative, or negligible, effect on marine primary producers - except in the specific case of some marine-terminating glaciers where a different mechanism seems to operate (see Sect. 5).

Two linked hypotheses can be proposed to explain these apparently contradictory arguments. One is that whilst lithogenic particles are potentially a bioaccessible source of $\mathrm{Fe}, \mathrm{P}$ and $\mathrm{Si}$, they are deficient in bioaccessible N. $\mathrm{As}^{\mathrm{NO}_{3}}$ availability is expected to limit primary production across much of the Arctic (Tremblay et al., 2015), this creates a spatial mismatch between nutrient supply and the nutrient demand required to increase Arctic primary production. A related, alternative hypothesis is that the negative effects of discharge on marine primary production (e.g. via stratification and light limitation from high turbidity) more than offset any positive effect that lithogenic particles have via increasing nutrient availability on regional scales prior to extensive sedimentation occurring. A similar conclusion has been reached from analysis of primary production in proglacial streams (Uehlinger et al., 2010). To some extent this reconciliation is also supported by considering the relative magnitudes of different physical and chemical processes acting on different spatial scales with respect to global marine primary production (see Sect. 10).

The generally low concentrations of macronutrients and dissolved organic matter (DOM) in glacier discharge, relative to coastal seawater (Table 2), have an important methodological implication because what constitutes a positive $\mathrm{NO}_{3}$, $\mathrm{PO}_{4}$ or DOM flux into the Arctic Ocean in a glaciological context can actually reduce short-term nutrient availability in the marine environment. It is therefore necessary to consider both the glacier discharge and saline endmembers that mix in fjords, alongside fjord-scale circulation patterns, in order to constrain the change in nutrient availability to marine biota (Meire et al., 2016a; Hopwood et al., 2018; Kanna et al., 2018).

Despite the relatively well constrained nutrient signature of glacial discharge around the Arctic, estimated fluxes of some nutrients from glaciers to the ocean appear to be subject to greater variability, especially for nutrients subject to non-conservative mixing (Table 3). Estimates of the Fe flux from the Greenland Ice Sheet, for example, have an 11-fold difference between the lowest $\left(>26 \mathrm{Mmol} \mathrm{yr}^{-1}\right.$ ) and highest $\left(290 \mathrm{Mmol} \mathrm{yr}^{-1}\right.$ ) values (Hawkings et al., 2014; Stevenson et al., 2017). However, it is debatable if these differences in $\mathrm{Fe}$ flux are significant because they largely arise in differences between definitions of the flux gate window and especially how estuarine Fe removal is accounted for. Given that the difference between an estimated removal factor of $90 \%$ and $99 \%$ is a factor of 10 difference in the calculated DFe flux, there is overlap in all of the calculated fluxes for Greenland Ice Sheet discharge into the ocean (Table 3) (Statham et al., 2008; Bhatia et al., 2013a; Hawkings et al., 2014; Stevenson et al., 2017). Conversely, estimates of DOM export (quantified as DOC) are confined to a slightly narrower range of 7$40 \mathrm{Gmol} \mathrm{yr}^{-1}$, with differences arising from changes in measured DOM concentrations (Bhatia et al., 2013b; Lawson et al., 2014b; Hood et al., 2015). The characterization of glacial DOM, with respect to its lability, $\mathrm{C}: \mathrm{N}$ ratio and implications for bacterial productivity in the marine environment (Hood et al., 2015; Paulsen et al., 2017), is however not readily apparent from a simple flux calculation.

A scaled-up calculation using freshwater concentrations $(C)$ and discharge volumes $(Q)$ is the simplest way of determining the flux from a glaciated catchment to the ocean. However, discharge nutrient concentrations vary seasonally (Hawkings et al., 2016; Wadham et al., 2016), often resulting in variable $C-Q$ relationships due to changes in mixing ratios between different discharge flow paths; post-mixing reactions; and seasonal changes in microbial behaviour in the snowpack, on glacier surfaces, and in proglacial forefields (Brown et al., 1994; Hodson et al., 2005). Therefore, full seasonal datasets from a range of representative glaciers are required to accurately describe $C-Q$ relationships. Furthermore, as the indirect effects of discharge on nutrient availability to phytoplankton via estuarine circulation and stratification are expected to be a greater influence than the direct nutrient outflow associated with discharge (Rysgaard et al., 2003; Juul-Pedersen et al., 2015; Meire et al., 2016a), freshwater data must be coupled to physical and chemical time series in the coastal environment if the net effect of discharge on nutrient availability in the marine environment is to be understood. Indeed, the recently emphasized hypothesis that nutrient fluxes from glaciers into the ocean have been significantly underestimated (Hawkings et al., 2016, 2017; Wadham et al., 2016) is difficult to reconcile with a synthesis and analysis of available marine nutrient distributions (Sect. 4) in glaciated Arctic catchments, especially for Si (Fig. 4).

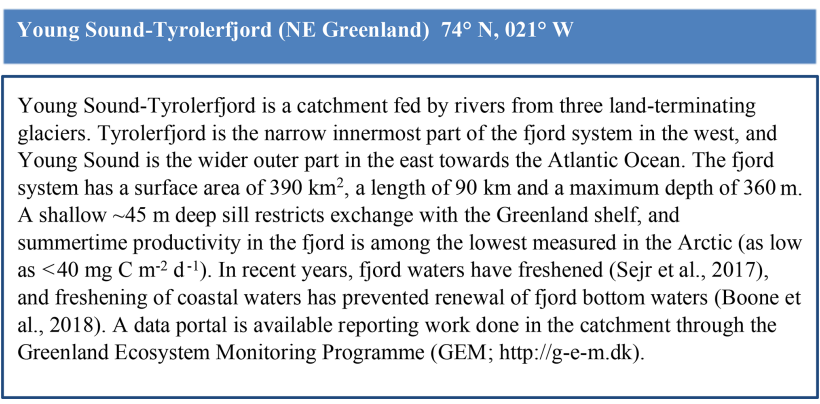

A particularly interesting case study concerning the link between marine primary production, circulation and discharge-derived nutrient fluxes is Young Sound. It was initially stipulated that increasing discharge into the fjord in response to climate change would increase estuarine circulation and therefore macronutrient supply. Combined with a longer sea-ice-free growing season as Arctic temperatures 
Table 2. Measured/computed discharge and saline endmembers for well-studied Arctic fjords (ND, not determined/not reported; BD, below detection).

\begin{tabular}{|c|c|c|c|c|c|c|}
\hline Fjord & Dataset & Salinity & $\mathrm{NO}_{3}(\mu \mathrm{M})$ & $\mathrm{PO}_{4}(\mu \mathrm{M})$ & $\mathrm{Si}(\mu \mathrm{M})$ & $\mathrm{TdFe}(\mu \mathrm{M})$ \\
\hline \multirow{3}{*}{$\begin{array}{l}\text { Kongsfjorden } \\
\text { (Svalbard) }\end{array}$} & \multirow{3}{*}{$\begin{array}{l}\text { Summer } 2016 \\
\text { (Cantoni et al., 2019) }\end{array}$} & 0.0 (ice melt) & $0.87 \pm 1.0$ & $0.02 \pm 0.03$ & $0.03 \pm 0.03$ & $33.8 \pm 100$ \\
\hline & & 0.0 (surface discharge) & $0.94 \pm 1.0$ & $0.057 \pm 0.31$ & $5.91 \pm 4.1$ & $74 \pm 76$ \\
\hline & & $34.50 \pm 0.17$ & $1.25 \pm 0.49$ & $0.20 \pm 0.06$ & $1.00 \pm 0.33$ & ND \\
\hline \multirow{3}{*}{$\begin{array}{l}\text { Nuup Kangerlua/ } \\
\text { Godthåbsfjord } \\
\text { (Greenland) }\end{array}$} & \multirow{3}{*}{$\begin{array}{l}\text { Summer } 2014 \\
\text { (Hopwood et al., 2016; } \\
\text { Meire et al., 2016a) }\end{array}$} & 0.0 (ice melt) & $1.96 \pm 1.68$ & $0.04 \pm 0.04$ & $13 \pm 15$ & $0.31 \pm 0.49$ \\
\hline & & 0.0 (surface discharge) & $1.60 \pm 0.44$ & $0.02 \pm 0.01$ & $12.2 \pm 16.3$ & 13.8 \\
\hline & & $33.57 \pm 0.05$ & $11.5 \pm 1.5$ & $0.79 \pm 0.04$ & $8.0 \pm 1.0$ & ND \\
\hline \multirow{3}{*}{$\begin{array}{l}\text { Sermilik } \\
\text { (Greenland) }\end{array}$} & \multirow{3}{*}{$\begin{array}{l}\text { Summer } 2015 \\
\text { (Cape et al., 2019) }\end{array}$} & 0.0 (subglacial discharge) & $1.8 \pm 0.5$ & ND & $10 \pm 8$ & ND \\
\hline & & 0.0 (ice melt) & $0.97 \pm 1.5$ & ND & $4 \pm 4$ & ND \\
\hline & & $34.9 \pm 0.1$ & $12.8 \pm 1$ & ND & $6.15 \pm 1$ & ND \\
\hline \multirow{2}{*}{$\begin{array}{l}\text { Bowdoin } \\
\text { (Greenland) }\end{array}$} & \multirow{2}{*}{$\begin{array}{l}\text { Summer } 2016 \\
\text { (Kanna et al., 2018) }\end{array}$} & 0.0 (surface discharge) & $0.22 \pm 0.15$ & $0.30 \pm 0.20$ & $\mathrm{BD}$ & ND \\
\hline & & $34.3 \pm 0.1$ & $14.7 \pm 0.9$ & $1.1 \pm 0.1$ & $19.5 \pm 1.5$ & ND \\
\hline \multirow{4}{*}{$\begin{array}{l}\text { Young Sound } \\
\text { (Greenland) }\end{array}$} & \multirow{4}{*}{$\begin{array}{l}\text { Summer } 2014 \\
\text { (Paulsen et al., 2017) }\end{array}$} & (Runoff July-August) & $1.2 \pm 0.74$ & $0.29 \pm 0.2$ & $9.52 \pm 3.8$ & ND \\
\hline & & (Runoff September-October) & $1.0 \pm 0.7$ & $0.35 \pm 0.2$ & $29.57 \pm 10.9$ & ND \\
\hline & & $33.6 \pm 0.1$ (July-August) & $6.4 \pm 1.1$ & $1.18 \pm 0.5$ & $6.66 \pm 0.4$ & ND \\
\hline & & $33.5 \pm 0.04$ (September-October) & $5.6 \pm 0.2$ & $0.62 \pm 0.2$ & $6.5 \pm 0.1$ & ND \\
\hline
\end{tabular}

increase, this would be expected to increase primary production within the fjord (Rysgaard et al., 1999; Rysgaard and Glud, 2007). Yet freshwater input also stratifies the fjord throughout summer and ensures low macronutrient availability in surface waters (Bendtsen et al., 2014; Meire et al., 2016a), which results in low summertime productivity in the inner and central fjord $\left(<40 \mathrm{mg} \mathrm{C} \mathrm{m}^{-2} \mathrm{~d}^{-1}\right)$ (Rysgaard et al., 1999, 2003; Rysgaard and Glud, 2007). Whilst annual discharge volumes into the fjord have increased over the past two decades, resulting in a mean annual $0.12 \pm 0.05$ (practical salinity units) freshening of fjord waters (Sejr et al., 2017), shelf waters have also freshened. This has potentially impeded the dense inflow of saline waters into the fjord (Boone et al., 2018) and therefore counteracted the expected increase in productivity.

\subsection{How do variations in the behaviour and location of higher-trophic-level organisms affect nutrient availability to marine microorganisms?}

With the exception of some zooplankton and fish species that struggle to adapt to the strong salinity gradients and/or suspended particle loads in inner-fjord environments (Wçslawski and Legezytńska, 1998; Lydersen et al., 2014), higher-trophic-level organisms (including mammals and birds) are not directly affected by the physical/chemical gradients caused by glacier discharge. However, their food sources, such as zooplankton and some fish species, are directly affected, and therefore there are many examples of higher-level organisms adapting their feeding strategies within glacier fjord environments (Arimitsu et al., 2012; Renner et al., 2012; Laidre et al., 2016). Strong gradients in physical/chemical gradients downstream of glaciers, particularly turbidity, can therefore create localized hotspots of secondary productivity in areas where primary production is low (Lydersen et al., 2014).

It is debatable to what extent shifts in these feeding patterns could have broadscale biogeochemical effects. Whilst some species are widely described as ecosystem engineers, such as Alle alle (the little auk) in the Greenland North Water Polynya (González-Bergonzoni et al., 2017), for changes in higher-trophic-level organisms' feeding habits to have significant direct chemical effects on the scale of a glacier fjord system would require relatively large concentrations of such animals. Nevertheless, in some specific hotspot regions this effect is significant enough to be measurable. There is ample evidence that birds intentionally target upwelling plumes in front of glaciers as feeding grounds, possibly due to the stunning effect that turbid, upwelling plumes have upon prey such as zooplankton (Hop et al., 2002; Lydersen et al., 2014). This feeding activity therefore concentrates the effect of avian nutrient recycling within a smaller area than would otherwise be the case, potentially leading to modest nutrient enrichment of these proglacial environments. Yet, with the exception of large, concentrated bird colonies, the effects of such activity are likely modest. In Kongsfjorden, bird populations are well studied, and several species are associated with feeding in proglacial plumes yet still collectively consume only between $0.1 \%$ and $5.3 \%$ of the carbon produced by phytoplankton in the fjord (Hop et al., 2002). The estimated corresponding nutrient flux into the fjord from birds is $2 \mathrm{mmol} \mathrm{m}^{-2} \mathrm{yr}^{-1}$ nitrogen and $0.3 \mathrm{mmol} \mathrm{m}^{-2} \mathrm{yr}^{-1}$ phosphorous. 
Table 3. Flux calculations for dissolved nutrients (Fe, DOC, DON, $\mathrm{NO}_{3}, \mathrm{PO}_{4}$ and $\mathrm{Si}$ ) from Greenland Ice Sheet discharge. Where a flux was not calculated in the original work, an assumed discharge volume of $1000 \mathrm{~km}^{3} \mathrm{yr}^{-1}$ is used to derive a flux for comparative purposes (ASi, amorphous silica; LPP, labile particulate phosphorous). For DOM, $\mathrm{PO}_{4}$ and $\mathrm{NO}_{3}$, non-conservative estuarine behaviour is expected to be minor or negligible. Note that whilst we have defined "dissolved" herein as $<0.2 \mu \mathrm{m}$, the sampling and filtration techniques used, particularly in freshwater studies, are not well standardized, and thus some differences may arise between studies accordingly. Clogging of filters in turbid waters reduces the effective filter pore size; DOP, DON, $\mathrm{NH}_{4}$ and $\mathrm{PO}_{4}$ concentrations often approach analytical detection limits which, alongside field/analytical blanks, are treated differently; low concentrations of $\mathrm{NO}_{3}, \mathrm{DON}, \mathrm{DOP}, \mathrm{DOC}, \mathrm{NH}_{4}$ and $\mathrm{DFe}$ are easily inadvertently introduced to samples by contamination, and measured Si concentrations can be significantly lower when samples have been frozen.

\begin{tabular}{|c|c|c|c|c|}
\hline Nutrient & $\begin{array}{r}\text { Freshwater } \\
\text { endmember } \\
\text { concentration } \\
(\mu \mathrm{M})\end{array}$ & Flux & Estuarine modification & Data \\
\hline \multirow[t]{5}{*}{$\mathrm{Fe}$} & 0.13 & $>26 \mathrm{Mmol} \mathrm{yr}^{-1}$ & Inclusive, $>80 \%$ loss & Hopwood et al. (2016) \\
\hline & 1.64 & $39 \mathrm{Mmol} \mathrm{yr}^{-1}$ & Assumed $90 \%$ loss & Stevenson et al. (2017) \\
\hline & 0.053 & $53 \mathrm{Mmol} \mathrm{yr}^{-1}$ & Discussed, not applied & Statham et al. (2008) \\
\hline & 3.70 & $180 \mathrm{Mmol} \mathrm{yr}^{-1}$ & Assumed $90 \%$ loss & Bhatia et al. (2013a) \\
\hline & 0.71 & $290 \mathrm{Mmol} \mathrm{yr}^{-1}$ & Discussed, not applied & Hawkings et al. (2014) \\
\hline \multirow[t]{5}{*}{ DOC } & $16-100$ & $6.7 \mathrm{Gmol} \mathrm{yr}^{-1}$ & Not discussed & Bhatia et al. $(2010,2013 b)$ \\
\hline & $12-41$ & $11-14 \mathrm{Gmol} \mathrm{yr}^{-1}$ & Not discussed & Lawson et al. (2014b) \\
\hline & $15-100$ & $18 \mathrm{Gmol} \mathrm{yr}^{-1}$ & Not discussed & Hood et al. (2015) \\
\hline & $2-290$ & $24-38 \mathrm{Gmol} \mathrm{yr}^{-1}$ & Not discussed & Csank et al. (2019) \\
\hline & $27-47$ & $40 \mathrm{Gmol} \mathrm{yr}^{-1}$ & Not discussed & Paulsen et al. (2017) \\
\hline \multirow[t]{2}{*}{ DON } & $4.7-5.4$ & $5 \mathrm{Gmol} \mathrm{yr}^{-1}$ & Not discussed & Paulsen et al. (2017) \\
\hline & 1.7 & $0.7-1.1 \mathrm{Gmol} \mathrm{yr}^{-1}$ & Not discussed & Wadham et al. (2016) \\
\hline \multirow[t]{2}{*}{$\mathrm{Si}$} & $13-28$ & $22 \mathrm{Gmol} \mathrm{yr}^{-1}$ & Inclusive & Meire et al. (2016a) \\
\hline & 9.6 & $4 \mathrm{Gmol} \mathrm{yr}^{-1}$ & $\begin{array}{l}\text { Discussed } \\
\left(+190 \mathrm{Gmol} \mathrm{yr}^{-1} \mathrm{ASi}\right)\end{array}$ & Hawkings et al. (2017) \\
\hline \multirow[t]{2}{*}{$\mathrm{PO}_{4}$} & 0.23 & $0.10 \mathrm{Gmol} \mathrm{yr}^{-1}$ & $\begin{array}{l}\text { Discussed } \\
\left(+0.23 \mathrm{Gmol} \mathrm{yr}^{-1} \mathrm{LPP}\right)\end{array}$ & Hawkings et al. (2016) \\
\hline & 0.26 & $0.26 \mathrm{Gmol} \mathrm{yr}^{-1}$ & Not discussed & Meire et al. (2016a) \\
\hline \multirow{3}{*}{$\mathrm{NO}_{3}$} & $1.4-1.5$ & $0.42 \mathrm{Gmol} \mathrm{yr}^{-1}$ & Not discussed & Wadham et al. (2016) \\
\hline & $0.5-1.7$ & $0.5-1.7 \mathrm{Gmol} \mathrm{yr}^{-1}$ & Not discussed & Paulsen et al. (2017) \\
\hline & 1.79 & $1.79 \mathrm{Gmol} \mathrm{yr}^{-1}$ & Not discussed & Meire et al. (2016a) \\
\hline
\end{tabular}

\section{Critical differences between surface and subsurface discharge release}

\section{Sermilik Fjord (SE Greenland) $66^{\circ} \mathrm{N}, 038^{\circ} \mathrm{W}$}

Sermilik Fjord is home to Helheim Glacier, Greenland's fifth largest in terms of annual discharge volume. The fjord is $\sim 100 \mathrm{~km}$ long and $\sim 600-900 \mathrm{~m}$ deep, with no sill to restrict fjord-shelf exchange. The circulation of water masses within the fjord, fjord-shelf exchange (Straneo et al., 2011; Beaird et al., 2018), and iceberg dynamics along the fjord have all been characterised. Whilst a large fraction (40-60\%) of freshwater from Greenland enters the ocean as solid ice, rather than as meltwater discharge, surprisingly little is known about the fate and effects of this component in the marine environment (Sutherland et al., 2014; Enderlin et al., 2018; Moon et al., 2018).

Critical differences arise between land-terminating and marine-terminating glaciers with respect to their effects on water column structure and associated patterns in primary production (Table 1). Multiple glacier fjord surveys have shown that fjords with large marine-terminating glaciers around the Arctic are normally more productive than their land-terminating glacier fjord counterparts (Meire et al., 2017; Kanna et al., 2018), and, despite large inter-fjord variability (Fig. 2), this observation appears to be significant across all available primary production data for Arctic glacier fjords (Table 1). A particularly critical insight is that fjordscale summertime productivity along the west Greenland coastline scales approximately with discharge downstream of marine-terminating glaciers but not land-terminating glaciers (Meire et al., 2017). The primary explanation for this phenomenon is the vertical nutrient flux associated with mixing driven by subglacial discharge plumes, which has been quantified in field studies at Bowdoin glacier (Kanna et al., 2018), 
Sermilik Fjord (Cape et al., 2019), Kongsfjorden (Halbach et al., 2019) and in Godthåbsfjord (Meire et al., 2016a).

As discharge is released at the glacial grounding line depth, its buoyancy and momentum result in an upwelling plume that entrains and mixes with ambient seawater (Carroll et al., 2015, 2016; Cowton et al., 2015). In Bowdoin, Sermilik and Godthåbsfjord, this nutrient pump provides $99 \%$, $97 \%$ and $87 \%$, respectively, of the $\mathrm{NO}_{3}$ associated with glacier inputs to each fjord system (Meire et al., 2016a; Kanna et al., 2018; Cape et al., 2019). Whilst the panArctic magnitude of this nutrient pump is challenging to quantify because of the uniqueness of glacier fjord systems in terms of their geometry, circulation, residence time and glacier grounding line depths (Straneo and Cenedese, 2015; Morlighem et al., 2017), it can be approximated in generic terms because plume theory (Morton et al., 1956) has been used extensively to describe subglacial discharge plumes in the marine environment (Jenkins, 2011; Hewitt, 2020). Computed estimates of subglacial discharge for the 12 Greenland glacier fjord systems where sufficient data are available to simulate plume entrainment (Carroll et al., 2016) suggest that the entrainment effect is at least 2 orders of magnitude more important for macronutrient availability than direct freshwater runoff (Hopwood et al., 2018). This is consistent with limited available field observations (Meire et al., 2016a; Kanna et al., 2018; Cape et al., 2019). As macronutrient fluxes have been estimated independently using different datasets and plume entrainment models in two of these glacier fjord systems (Sermilik and Illulissat), an assessment of the robustness of these fluxes can also be made (Table 4) (Hopwood et al., 2018; Cape et al., 2019). Exactly how these plumes, and any associated fluxes, will change with the combined effects of glacier retreat and increasing glacier discharge remains unclear (De Andrés et al., 2020) but may lead to large changes in fjord biogeochemistry (Torsvik et al., 2019). Despite different definitions of the macronutrient flux (Table 4; "A" refers to the out-of-fjord transport at a defined fjord cross-section window, whereas " $\mathrm{B}$ " refers to the vertical transport within the immediate vicinity of the glacier), the fluxes are reasonably comparable and in both cases unambiguously dominate macronutrient glacier-associated input into these fjord systems (Hopwood et al., 2018; Cape et al., 2019).

Whilst large compared to changes in macronutrient availability from discharge without entrainment (Table 3), it should be noted that these nutrient fluxes (Table 4) are still only intermediate contributions to fjord-scale macronutrient supply compared to total annual consumption in these environments. For example, in Godthåbsfjord mean annual primary production is $103.7 \mathrm{~g} \mathrm{C} \mathrm{m}^{-2} \mathrm{yr}^{-1}$, equivalent to biological consumption of $1.1 \mathrm{~mol} \mathrm{~N} \mathrm{~m}^{-2} \mathrm{yr}^{-1}$. Entrainment from the three marine-terminating glaciers within the fjord is conservatively estimated to supply $0.01-0.12 \mathrm{~mol} \mathrm{~N} \mathrm{~m}^{-2} \mathrm{yr}^{-1}$ (Meire et al., 2017), i.e. 1\%-11\% of the total $\mathrm{N}$ supply required for primary production if production were supported exclusively by new $\mathrm{NO}_{3}$ (rather than recycling) and equally distributed across the entire fjord surface. Whilst this is consistent with observations suggesting relative stability in mean annual primary production in Godthåbsfjord from 2005 to 2012 (103.7 $\pm 17.8 \mathrm{~g} \mathrm{C} \mathrm{m}^{-2} \mathrm{yr}^{-1}$; Juul-Pedersen et al., 2015), despite pronounced increases in total discharge into the fjord, this does not preclude a much stronger influence of entrainment on primary production in the inner-fjord environment. The time series is constructed at the fjord mouth, over $120 \mathrm{~km}$ from the nearest glacier, and the estimates of subglacial discharge and entrainment used by Meire et al. (2017) are both unrealistically low. If the same conservative estimate of entrainment is assumed to only affect productivity in the main fjord branch (where the three marine-terminating glaciers are located), for example, the lower bound for the contribution of entrainment becomes 3\%-33\% of total N supply. Similarly, in Kongsfjorden - the surface area of which is considerably smaller compared to Godthåbsfjord $\left(\sim 230 \mathrm{~km}^{2}\right.$ compared to $650 \mathrm{~km}^{2}$ ) - even the relatively weak entrainment from shallow marine-terminating glaciers (Fig. 5) accounts for approximately $19 \%-32 \%$ of $\mathrm{N}$ supply. An additional mechanism of $\mathrm{N}$ supply evident there, which partially offsets the inefficiency of macronutrient entrainment at shallow grounding line depths, is the entrainment of ammonium from shallow benthic sources (Halbach et al., 2019), which leads to unusually high $\mathrm{NH}_{4}$ concentrations in surface waters. Changes in subglacial discharge, or in the entrainment factor (e.g. from a shift in glacier grounding line depth, Carroll et al., 2016), can therefore potentially change fjord-scale productivity.

A specific deficiency in the literature to date is the absence of measured subglacial discharge rates from marineterminating glaciers. Variability in such rates on diurnal and seasonal timescales is expected (Schild et al., 2016; Fried et al., 2018), and intermittent periods of extremely high discharge are known to occur, for example from ice-dammed lake drainage in Godthåbsfjord (Kjeldsen et al., 2014). Yet determining the extent to which these events affect fjordscale mixing and biogeochemistry, as well as how these rates change in response to climate forcing, will require further field observations. Paradoxically, one of the major knowledge gaps concerning low-frequency, high-discharge events is their biological effects; yet these events first became characterized in Godthåbsfjord after observations by a fisherman of a sudden Sebastes marinus (Redfish) mortality event in the vicinity of a marine-terminating glacier terminus. These unfortunate fish were propelled rapidly to the surface by ascending freshwater during a high-discharge event (Kjeldsen et al., 2014).

A further deficiency, yet to be specifically addressed in biogeochemical studies, is the decoupling of different mixing processes in glacier fjords. In this section we have primarily considered the effect of subglacial discharge plumes on $\mathrm{NO}_{3}$ supply to near-surface waters downstream of marineterminating glaciers (Fig. 5). Yet a similar effect can arise from down-fjord katabatic winds which facilitate the out- 
Table 4. A comparison of upwelled $\mathrm{NO}_{3}$ fluxes calculated from fjord-specific observed nutrient distributions (A) (Cape et al., 2019) and using regional nutrient profiles with idealized plume theory (B) (Hopwood et al., 2018). "A" refers to the out-of-fjord transport of nutrients, whereas " $\mathrm{B}$ " refers to the vertical transport close to the glacier terminus.

\begin{tabular}{lrrr}
\hline Location & $\begin{array}{r}\text { Field } \\
\text { campaign(s) } \\
\text { for A }\end{array}$ & $\begin{array}{r}\text { (A) Calculated } \\
\text { out-of-fjord } \mathrm{NO}_{3} \\
\text { export Gmol yr }\end{array}$ & $\begin{array}{r}\text { (B) Idealized } \\
\mathrm{NO}_{3} \text { upwelling } \\
\mathrm{Gmol} \mathrm{yr}^{-1}\end{array}$ \\
\hline $\begin{array}{l}\text { Ilulissat Icefjord } \\
\text { (Jakobshavn Isbræ) }\end{array}$ & $2000-2016$ & $2.9 \pm 0.9$ & 4.2 \\
$\begin{array}{l}\text { Sermilik (Helheim Glacier) } \\
\text { Sermilik (Helheim Glacier) }\end{array}$ & 2015 & 0.88 & 2.0 \\
\hline
\end{tabular}

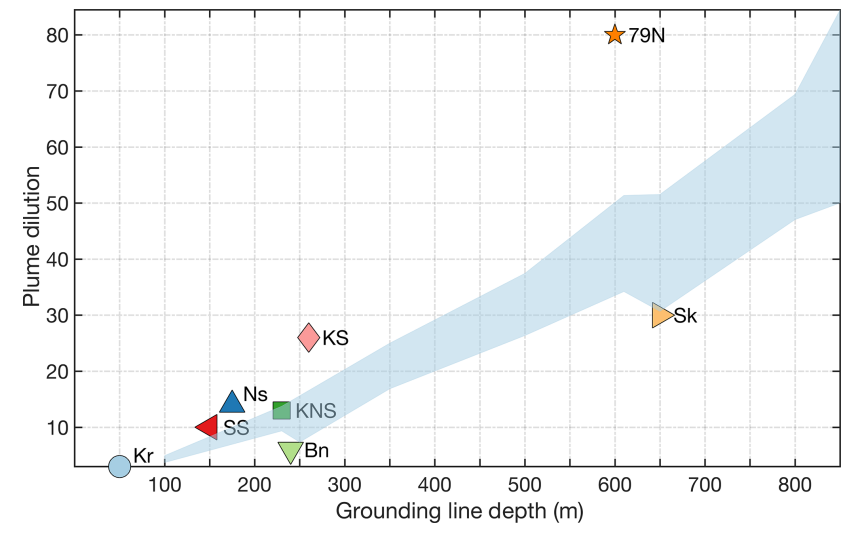

Figure 5. The plume dilution (entrainment) factor relationship with glacier grounding line depth as modelled by Carroll et al. (2016) for subglacial freshwater discharge rates of $250-500 \mathrm{~m}^{3} \mathrm{~s}^{-1}$ and grounding lines of $>100 \mathrm{~m}$ (shaded area). Also shown are the entrainment factors determined from field observations for Kronebreen (Kongsfjorden, Kr, Halbach et al., 2019), Bowdoin (Bn, Kanna et al., 2018), Saqqarliup Sermia (SS, Mankoff et al., 2016), Narsap Sermia (Ns, Meire et al., 2016a), Kangerlussuup Sermia (KS, Jackson et al., 2017), Kangiata Nunaata Sermia (KNS, Bendtsen et al., 2015), Sermilik (Sk, Beaird et al., 2018) and Nioghalvfjerdsfjorden Glacier (the " $79^{\circ} \mathrm{N}$ Glacier", 79N, Schaffer et al., 2020). Note that the $79^{\circ} \mathrm{N}$ Glacier is unusual compared to the other Arctic systems displayed as subglacial discharge there enters a large cavity beneath a floating ice tongue and accounts for only $11 \%$ of meltwater entering this cavity, with the rest derived from basal ice melt (Schaffer et al., 2020).

of-fjord transport of low-salinity surface waters and the inflow of generally macronutrient-rich saline waters at depth (Svendsen et al., 2002; Johnson et al., 2011; Spall et al., 2017). Both subglacial discharge and down-fjord winds therefore contribute to physical changes affecting macronutrient availability on a similar spatial scale, and both processes are expected to be subject to substantial short-term (hours-days), seasonal and inter-fjord variability, which is presently poorly constrained (Spall et al., 2017; Sundfjord et al., 2017).

\subsection{Is benthic-pelagic coupling enhanced by subglacial discharge?}

The attribution of unusually high near-surface $\mathrm{NH}_{4}$ concentrations in surface waters of Kongsfjorden to benthic release in this relatively shallow fjord, followed by upwelling close to the Kronebreen calving front (Halbach et al., 2019), raises questions about where else this phenomenon could be important and which other biogeochemical compounds could be made available to pelagic organisms by such enhanced benthic-pelagic coupling. The summertime discharge-driven upwelling flux within a glacier fjord of any chemical which is released into bottom water from sediments, for example $\mathrm{Fe}$, Mn (Wehrmann et al., 2014), dissolved organic phosphorous (DOP), dissolved organic nitrogen (DON) (Koziorowska et al., 2018) or Si (Hendry et al., 2019), could potentially be increased to varying degrees depending on sediment composition (Wehrmann et al., 2014; Glud et al., 2000) and the interrelated nature of fjord circulation, topography and the depth range over which entrainment occurs.

Where such benthic-upwelling coupling does occur close to glacier termini it may be challenging to quantify from water column observations due to the overlap with other processes causing nutrient enrichment. For example, the moderately high dissolved $\mathrm{Fe}$ concentrations observed close to Antarctic ice shelves were classically attributed mainly to direct freshwater inputs, but it is now thought that the direct freshwater input and the Fe entering surface waters from entrainment of Fe-enriched near-bottom waters could be comparable in magnitude (St-Laurent et al., 2017), although with large uncertainty. This adds further complexity to the role of coastal, fjord and glacier geometry in controlling nutrient bioaccessibility, and determining the significance of such coupling is a priority for hybrid model-field studies.

\subsection{From pelagic primary production to the carbon sink}

Whilst primary production is a major driver of $\mathrm{CO}_{2}$ drawdown from the atmosphere to the surface ocean, much of this $\mathrm{C}$ is subject to remineralization and, following bacterial or photochemical degradation of organic carbon, re-enters the 
atmosphere as $\mathrm{CO}_{2}$ on short timescales. The biological $\mathrm{C}$ pump refers to the small fraction of sinking $\mathrm{C}$ which is sequestered in the deep ocean or in sediments. There is no simple relationship between primary production and $\mathrm{C}$ export into the deep ocean as a range of primary-productionC-export relationships have been derived globally with the underlying cause subject to ongoing discussion (Le Moigne et al., 2016; Henson et al., 2019).

Irrespective of global patterns, glacier fjords are notable for their extremely high rates of sedimentation due to high lithogenic particle inputs (Howe et al., 2010). In addition to terrestrially derived material providing additional organic carbon for burial in fjords (Table 3), ballasting of sinking POC (particulate organic carbon) by lithogenic material generally increases the efficiency of the biological $\mathrm{C}$ pump by facilitating more rapid transfer of $\mathrm{C}$ to depth (Iversen and Robert, 2015; Pabortsava et al., 2017). With high sediment loads and steep topography, fjords are therefore expected to be efficient POC sinks, especially when normalized with respect to their surface area (Smith et al., 2015). Organic carbon accumulation rates in Arctic glacier fjords are far lower than temperate fjord systems, likely due to a combination of generally lower terrestrially derived carbon inputs and sometimes lower marine primary production, but Arctic fjords with glaciers still exhibit higher $\mathrm{C}$ accumulation than Arctic fjords without glaciers (Włodarska-Kowalczuk et al., 2019).

The limited available POC fluxes for Arctic glacier fjords support the hypothesis that they are efficient regions of POC export (Wiedmann et al., 2016; Seifert et al., 2019). POC equivalent to $28 \%-82 \%$ of primary production was found to be transferred to $>100 \mathrm{~m}$ depth in Nordvestfjord (west Greenland) (Seifert et al., 2019). This represents mediumto-high export efficiency compared to other marine environments on a global scale (Henson et al., 2019). High lithogenic particle inputs into Arctic glacier fjords could therefore be considered to maintain a low-primary-production-high-Cexport-efficiency regime. On the one hand, they limit light availability and thus contribute to relatively low levels of primary production (Table 1), but concurrently they ensure that a relatively high fraction of $\mathrm{C}$ fixed by primary producers is transferred to depth (Seifert et al., 2019).

Beyond the potent impact of high sedimentation on benthic ecosystems (Włodarska-Kowalczuk et al., 2001, 2005), which is beyond the scope of this review, and the ballasting effect, which is sparsely studied in this environment to date (Seifert et al., 2019), relatively little is known about the interactive effects of concurrent biogeochemical processes on glacier-derived particle surfaces occurring during their suspension (or resuspension) in near-shore waters. Chemical processes occurring at turbid freshwater-saline interfaces such as dissolved Fe and DOM scavenging onto particle surfaces and phosphate or DOM co-precipitation with Fe oxyhydroxides (e.g. Sholkovitz et al., 1978; Charette and Sholkovitz, 2002; Hyacinthe and Van Cappellen, 2004) have yet to be extensively studied in Arctic glacier estuaries where they may exert some influence on nutrient availability and C cycling.

\section{Contrasting $\mathrm{Fe}$ - and $\mathrm{NO}_{3}$-limited regions of the ocean}

Whether or not nutrients transported to the ocean surface have an immediate positive effect on marine primary production depends on the identity of the resource(s) that limits marine primary production. Light attenuation is the ultimate limiting control on marine primary production and is exacerbated close to turbid glacial outflows (Hop et al., 2002; Arimitsu et al., 2012; Murray et al., 2015). However the spatial extent of sediment plumes and/or ice mélange, which limit light penetration into the water column, is typically restricted to within kilometres of the glacier terminus (Arimitsu et al., 2012; Hudson et al., 2014; Lydersen et al., 2014). Beyond the turbid, light-limited vicinity of glacial outflows, the proximal limiting resource for summertime marine primary production will likely be a nutrient, the identity of which varies with location globally (Moore et al., 2013). Increasing the supply of the proximal limiting nutrient would be expected to have a positive influence on marine primary production, whereas increasing the supply of other nutrients alone would not - a premise of "the law of the minimum" (Debaar, 1994). Although proximal limiting nutrient availability controls total primary production, organic carbon and nutrient stoichiometry nevertheless has specific effects on the predominance of different phytoplankton and bacterial groups (Egge and Aksnes, 1992; Egge and Heimdal, 1994; Thingstad et al., 2008).

The continental shelf is a major source of $\mathrm{Fe}$ into the ocean (Lam and Bishop, 2008; Charette et al., 2016), and this results in clear differences in proximal limiting nutrients between Arctic and Antarctic marine environments. The isolated Southern Ocean is the world's largest high-nitrate, lowchlorophyll (HNLC) zone where Fe extensively limits primary production even in coastal polynyas (Sedwick et al., 2011) and macronutrients are generally present at high concentrations in surface waters (Martin et al., 1990a, b). Conversely, the Arctic Ocean is exposed to extensive broad shelf areas with associated Fe input from rivers and shelf sediments and thus generally has a greater availability of $\mathrm{Fe}$ relative to macronutrient supply (Klunder et al., 2012). Felimited summertime conditions have been reported in parts of the Arctic and sub-Arctic (Nielsdottir et al., 2009; RyanKeogh et al., 2013; Rijkenberg et al., 2018) but are spatially and temporally limited compared to the geographically extensive HNLC conditions in the Southern Ocean.

However, few experimental studies have directly assessed the nutrient limitation status of regions within the vicinity of glaciated Arctic catchments. With extremely high $\mathrm{Fe}$ input into these catchments, $\mathrm{NO}_{3}$ limitation might be expected year-round. However, $\mathrm{PO}_{4}$ limitation is also plausible close to glaciers in strongly stratified fjords (Prado-Fiedler, 2009), due to the low availability of $\mathrm{PO}_{4}$ in freshwater rel- 
ative to $\mathrm{NO}_{3}$ (Ren et al., 2019). Conversely, in the Southern Ocean, it is possible that Fe-limited conditions occur extremely close to glaciers and ice shelves (Fig. 6). High$\mathrm{NO}_{3}$, low-Fe water can be found in the immediate vicinity of Antarctica's coastline (Gerringa et al., 2012; Marsay et al., 2017) and even in inshore bays (Annett et al., 2015; Höfer et al., 2019). Macronutrient data from Maxwell Bay (King George Island, South Shetland Islands), for example, suggest that $\mathrm{Fe}$ from local glaciers mixes with high- $\mathrm{NO}_{3}$, high-Si ocean waters, providing ideal conditions for phytoplankton blooms in terms of nutrient availability. The lowest surface macronutrient concentrations measured in Maxwell Bay in a summer campaign were $17 \mu \mathrm{MNO}_{3}, 1.4 \mu \mathrm{MPO}_{4}$ and $47 \mu \mathrm{M}$ Si (Höfer et al., 2019). Similarly, in Ryder Bay (Antarctic Peninsula), the lowest measured annual macronutrient concentrations - occurring after strong drawdown during a pronounced phytoplankton bloom $\left(22 \mathrm{mg} \mathrm{m}^{-3}\right.$ chlorophyll $a$ ) - were $2.5 \mu \mathrm{M} \mathrm{NO}_{3}$ and $0.4 \mu \mathrm{M} \mathrm{PO}_{4}$ (Annett et al., 2015). This contrasts starkly with the summertime surface macronutrient distribution in glaciated fjords in the Arctic, including Kongsfjorden (Fig. 3), where surface macronutrient concentrations are typically depleted throughout summer. These differences may explain why some Antarctic glacier fjords have significantly higher chlorophyll and biomass than any of the Arctic glacier fjord systems considered herein (Mascioni et al., 2019). However, we note a general lack of seasonal and interannual data for Antarctic glacier fjord systems precludes a comprehensive inter-comparison of these different systems.

For a hypothetical nutrient flux from a glacier, the same flux could be envisaged in two endmember scenarios: one several kilometres inside an Arctic fjord (e.g. Godthåbsfjord or Kongsfjorden); and one at the coastline of an isolated Southern Ocean island such as the Kerguelen (Bucciarelli et al., 2001; Bowie et al., 2015), Heard (van der Merwe et al., 2019) or South Shetland Islands (Höfer et al., 2019). In the Arctic fjord, a pronounced Fe flux from summertime discharge would likely have no immediate positive effect upon fjord-scale marine primary production because Fe may already be replete (Hopwood et al., 2016; Crusius et al., 2017). This is consistent with the observation that Fe-rich discharge from land-terminating glaciers around west Greenland does not have a positive fjord-scale fertilization effect (Meire et al., 2017) and may possibly be associated with a negative effect (Table 1). Conversely, the same Fe input into coastal waters around the Kerguelen Islands would be expected to have a pronounced positive effect upon marine primary production, because the islands occur within the world's largest HNLC zone. Where Fe is advected offshore in the wake of the islands, a general positive effect on primary production is expected (Blain et al., 2001; Bucciarelli et al., 2001) even though there are marked changes in the phytoplankton community composition between the Fe-enriched bloom region (dominated by microphytoplankton) and the offshore HNLC area (dominated by small diatoms and nanoflagellates) (Uitz
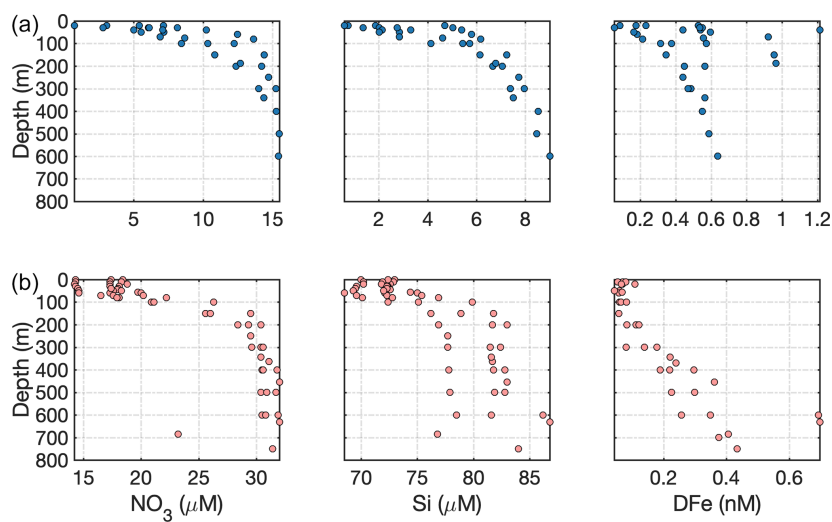

Figure 6. Contrasting nutrient properties of water on the (a) southeast Greenland shelf (data from Achterberg et al., 2018) with (b) the Ross Sea shelf (data from Marsay et al., 2017). Note the different scales used on the $x$ axes.

et al., 2009). However, even in these HNLC waters there are also other concurrent factors that locally mitigate the effect of glacially derived Fe in nearshore waters, because light limitation from near-surface particle plumes may locally offset any positive effect of Fe fertilization (Wojtasiewicz et al., 2019).

\subsection{The subglacial discharge pump; from macronutrients to iron}

The effect of the subglacial discharge nutrient pump may similarly vary with location. Contrasting the $\mathrm{NO}_{3}$ and $\mathrm{DFe}$ concentrations of marine environments observed adjacent to different glacier systems suggests substantial variations in the proximal limiting nutrient of these waters on a global scale (Fig. 7). In Antarctic shelf regions, such as the western Antarctic Peninsula, a high log-transformed ratio of summertime $\mathrm{NO}_{3}$ : DFe (median value 2) is indicative of Fe limitation. Across the Arctic there is a broader range of ratios (median values -1.2 to 1.3 ) indicating spatial variability in the balance between $\mathrm{Fe}$ and $\mathrm{NO}_{3}$ limitation (Fig. 7). Variation is evident even within specific regions. The range of $\mathrm{NO}_{3}: \mathrm{DFe}$ ratios for both the Gulf of Alaska $\left(\log _{10}-2.5\right.$ to 1.7$)$ and the south Greenland shelf $\left(\log _{10}-1.5\right.$ to 1.8$)$ includes values that are indicative of the full spectrum of responses from $\mathrm{NO}_{3}$ limitation to $\mathrm{Fe} / \mathrm{NO}_{3}$ co-limitation to $\mathrm{Fe}$ limitation (Browning et al., 2017). This suggests a relatively rapid spatial transition from excess to deficient $\mathrm{DFe}$ conditions.

How would the marine-terminating glacier upwelling effect operate in an Fe-limited system? The physical mechanism of a nutrient pump would be identical for glaciers with the same discharge and grounding line: one in a high-Fe, low$\mathrm{NO}_{3}$ Arctic system and one in a low-Fe, high- $\mathrm{NO}_{3}$ Antarctic system. However, the biogeochemical consequences with respect to marine primary production would be different (Table 5). In the case of subglacial discharge, for simplicity, we consider a mid-depth glacier (grounding line of 100-250 m 


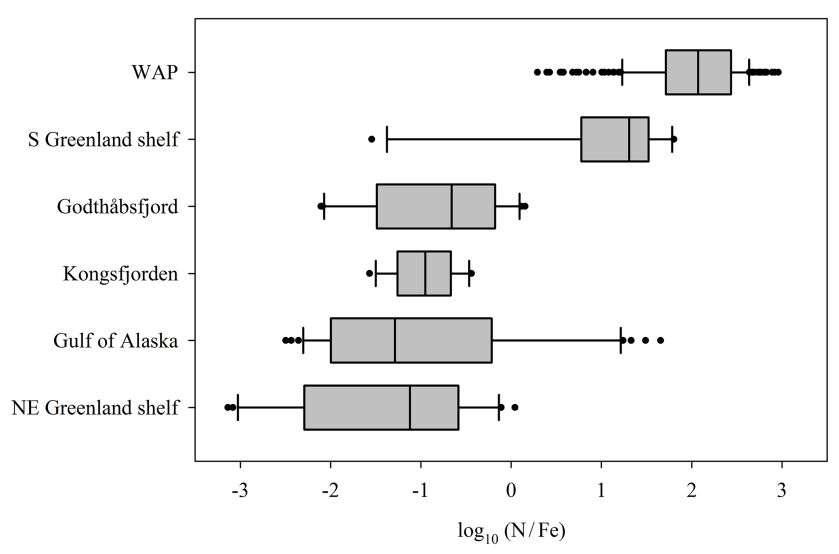

Figure 7. Variations in the ratio of dissolved $\mathrm{NO}_{3}$ and $\mathrm{Fe}$ in surface waters $(<20 \mathrm{~m})$ adjacent to glaciated regions: whiskers show the 10th and 90th percentiles; bars shows the median, 25th percentile and 75th percentile; and dots show all outliers. Data from the western Antarctic Peninsula (WAP, Annett et al., 2017; Ducklow et al., 2017), the south Greenland shelf (Achterberg et al., 2018; Tonnard et al., 2020), Godthåbsfjord (Hopwood et al., 2016), Kongsfjorden (Hopwood et al., 2017), the Gulf of Alaska (Lippiatt et al., 2010) and the NE Greenland shelf (Hopwood et al., 2018). For Kongsfjorden, $\mathrm{NO}_{3}$ and $\mathrm{Fe}$ data were interpolated using the $\mathrm{NO}_{3}$-salinity relationship.

below sea level) with a constant discharge rate of $250 \mathrm{~m}^{3} \mathrm{~s}^{-1}$. An entrainment factor of 6-10 would then be predicted by plume theory (Fig. 5) (Carroll et al., 2016). In a Greenland fjord with no sill to constrain circulation and a residence time short enough that inflowing nutrient concentrations were not changed significantly prior to entrainment, an average $\mathrm{NO}_{3}$ concentration of $5-12 \mu \mathrm{M}$ is predicted in the entrained water compared to $\sim 2 \mu \mathrm{M}$ in glacier discharge (Hopwood et al., 2018). Over a 2-month discharge period, this would produce a $\mathrm{NO}_{3}$ flux of $40-160 \mathrm{Mmol} \mathrm{NO}_{3}$, with $2 \%-6 \%$ of the $\mathrm{NO}_{3}$ flux arising from meltwater discharge and $94 \%-98 \%$ from plume entrainment. Complete utilization of this $\mathrm{NO}_{3}$ by phytoplankton according to the Redfield ratio (106 C : $16 \mathrm{~N}$ ) (Redfield, 1934) would correspond to a biological sink of 0.27-1.0 Gmol C.

In an analogous $\mathrm{HNLC}$ environment, surface $\mathrm{NO}_{3}$ requirements would already vastly exceed phytoplankton requirements (Fig. 7) due to extensive Fe limitation of primary production. Thus, whilst the upwelled $\mathrm{NO}_{3}$ flux would be larger in an Fe-limited system, due to higher concentrations of $\mathrm{NO}_{3}$ in the water column (see Fig. 6), the short-term biological effect of upwelling $\mathrm{NO}_{3}$ alone would be negligible. More important would be the upwelling of the proximal limiting nutrient $\mathrm{Fe}$. If we assume that dissolved $\mathrm{Fe}$ in the marine water column is in a stable, bioavailable form and that additional dissolved Fe from freshwater is delivered to the marine environment with a $90 \%-99 \%$ loss during estuarine mixing (Table 3), the upwelled Fe flux can be estimated. Upwelled unmodified water from a depth of $100-250 \mathrm{~m}$ would be ex- pected to contain $0.06-0.12 \mathrm{nMFe}$ (Marsay et al., 2017). The freshwater endmember in the context of an Antarctic calving ice front would largely consist of ice melt (rather than subglacial discharge, Hewitt, 2020), so we use an intermediate freshwater Fe endmember of $33-680 \mathrm{nM}$ in ice melt (Annett et al., 2017; Hodson et al., 2017). Upwelling via the same hypothetical $250 \mathrm{~m}^{3} \mathrm{~s}^{-1}$ discharge as per the Arctic scenario would generate a combined upwelled and discharge flux (after estuarine removal processes) of 0.89$89 \mathrm{kmol} \mathrm{Fe}$ with $2 \%-52 \%$ of the $\mathrm{Fe}$ arising from upwelling and $48 \%-98 \%$ from freshwater. Using an intermediate $\mathrm{Fe}$ : $\mathrm{C}$ value of $5 \mathrm{mmol} \mathrm{Fe} \mathrm{mol}^{-1} \mathrm{C}$, which is broadly applicable to the coastal environment (Twining and Baines, 2013), this would correspond to a biological pool of $0.019-1.9 \mathrm{Gmol} \mathrm{C}$. It should be noted that the uncertainty on this calculation is particularly large because, unlike $\mathrm{NO}_{3}$ upwelling, there is a lack of in situ data to constrain the simultaneous mixing and non-conservative behaviour of $\mathrm{Fe}$.

For a surface discharge of $250 \mathrm{~m}^{3} \mathrm{~s}^{-1}$, nutrient entrainment is assumed to be negligible. In the case of $\mathrm{Fe}$ outflow into a low-Fe, high- $\mathrm{NO}_{3}$ system, we assume that the glacier outflow is the dominant local $\mathrm{Fe}$ source over the fertilized area during the discharge period (i.e. changes to other sources of Fe such as the diffusive flux from shelf sediments are negligible). For the case of surface discharge into a low- $\mathrm{NO}_{3}$, high-Fe system, this is not likely to be the case for $\mathrm{NO}_{3}$. Stratification induced by discharge decreases the vertical flux of $\mathrm{NO}_{3}$ from below, thus negatively affecting $\mathrm{NO}_{3}$ supply, although there are to our knowledge no studies quantifying this change in glacially modified waters.

It is clear from these simplified discharge scenarios (Table 5) that both the depth at which glacier discharge is released into the water column and the relative availabilities of $\mathrm{NO}_{3}$ and $\mathrm{Fe}$ in downstream waters could be critical for determining the response of primary producers. The response of primary producers in low-Fe regimes is notably subject to much larger uncertainty, mainly because of uncertainty in the extent of Fe removal during estuarine mixing (Schroth et al., 2014; Zhang et al., 2015). Whilst the effects of the marineterminating glacier nutrient pump on macronutrient fluxes have been defined in numerous systems, its effect on $\mathrm{Fe}$ availability is poorly constrained (Gerringa et al., 2012; StLaurent et al., 2017, 2019). Furthermore, Fe bioavailability is conceptually more complicated than discussed herein, as marine organisms at multiple trophic levels affect the speciation, bioaccessibility and bioavailability of $\mathrm{Fe}$, as well as the transfer between less-labile and more-labile Fe pools in the marine environment (Poorvin et al., 2004; Vraspir and Butler, 2009; Gledhill and Buck, 2012). Many microbial species release organic ligands into solution, which stabilize dissolved $\mathrm{Fe}$ as organic complexes. These feedbacks are challenging to model (Strzepek et al., 2005) but may exert a cap on the lateral transfer of Fe away from glacier inputs (Lippiatt et al., 2010; Thuroczy et al., 2012). To date, Fe fluxes from glaciers into the ocean have primarily been constructed from an inor- 
Table 5. Suppositional effect of different discharge scenarios calculated from the Redfield ratio $106 \mathrm{C}: 16 \mathrm{~N}: 1 \mathrm{P}: 0.005 \mathrm{Fe}$ (Redfield, 1934 ; Twining and Baines, 2013). A steady freshwater discharge of $250 \mathrm{~m}^{3} \mathrm{~s}^{-1}$ is either released from a land-terminating glacier or from a marineterminating glacier at 100-250 m depth, in both cases for two months into Fe-replete, $\mathrm{NO}_{3}$-deficient or Fe-deficient, $\mathrm{NO}_{3}$-replete marine environments. Freshwater endmembers are defined as $2 \mu \mathrm{MNO}_{3}$ and 33-675 nM dissolved Fe (Annett et al., 2017; Hodson et al., 2017; Hopwood et al., 2018). Ambient water column conditions are defined as Greenland (Achterberg et al., 2018) (i.e. high-Fe, low-NO 3 ) and Ross Sea (Marsay et al., 2017) (i.e. low-Fe, high-NO 3 ) shelf profiles.

\begin{tabular}{lll}
\hline & Surface discharge & Subglacial discharge \\
\hline $\begin{array}{l}\text { High-Fe, low- } \mathrm{NO}_{3} \\
\text { environment } \\
\text { (predominant Arctic condition) }\end{array}$ & $\begin{array}{l}\text { e.g. Young Sound } \\
<0-0.017 \mathrm{GmolC}\end{array}$ & $\begin{array}{l}\text { e.g. Bowdoin Fjord, } \\
\text { Sermilik } \\
0.27-1.0 \mathrm{Gmol} \mathrm{C}\end{array}$ \\
\hline $\begin{array}{l}\text { Low-Fe, high- } \mathrm{NO}_{3} \text { environment } \\
\text { (predominant Antarctic }\end{array}$ & e.g. Antarctic Peninsula & e.g. Antarctic Peninsula \\
condition) & $0.009-1.9$ Gmol C & $0.019-1.9$ Gmol C \\
\hline
\end{tabular}

ganic, freshwater perspective (Raiswell et al., 2006; Raiswell and Canfield, 2012; Hawkings et al., 2014). Yet to understand the net change in Fe availability to marine biota, a greater understanding of how ligands and estuarine mixing processes moderate the glacier-to-ocean Fe transfer will evidently be required (Lippiatt et al., 2010; Schroth et al., 2014; Zhang et al., 2015).

\section{Effects on the carbonate system}

Beyond its impact on inorganic nutrient dynamics, glacial discharge also affects the inorganic carbon system, commonly referred to as the carbonate system, in seawater. The carbonate system describes the seawater buffer system and consists of dissolved $\mathrm{CO}_{2}$ and carbonic acid, bicarbonate ions and carbonate ions. These components buffer $\mathrm{pH}$ and are the main reason for the ocean's capacity to absorb atmospheric $\mathrm{CO}_{2}$. The interaction between these chemical species, which varies with physical conditions including temperature and salinity (Dickson and Millero, 1987), dictates the $\mathrm{pH}$ of seawater and the saturation state of biologically important carbonate minerals such as aragonite and calcite ( $\Omega \mathrm{Ar}$ and $\Omega \mathrm{Ca}$, respectively). Discharge generally reduces the total alkalinity (TA, buffering capacity) of glacially modified waters mainly through dilution (Fig. 8), which results in a decreased carbonate ion concentration. Since carbonate ions are the main control on the solubility of $\mathrm{CaCO}_{3}$, decreasing carbonate ion availability due to meltwater dilution negatively impacts the aragonite and calcite saturation state (Doney et al., 2009; Fransson et al., 2015). Glacier discharge can also moderate the carbonate system indirectly, as higher primary production leads to increased biological dissolved inorganic carbon (DIC) uptake, lower $p \mathrm{CO}_{2}$ and thus higher $\mathrm{pH}$ in seawater. Therefore increasing or decreasing primary production also moderates $\mathrm{pH}$ and the aragonite and calcite saturation state of marine surface waters.

Total alkalinity measurements of glacial discharge across the Arctic reveal a range from 20 to $550 \mu \mathrm{mol} \mathrm{kg}-1$ (Yde et al., 2005; Sejr et al., 2011; Rysgaard et al., 2012; Evans et al., 2014; Fransson et al., 2015, 2016; Meire et al., 2015; Turk et al., 2016). Similar to Si concentrations, the broad range is likely explained by different degrees of interaction between meltwater and bedrock, with higher alkalinity corresponding to greater discharge-bedrock interaction (Wadham et al., 2010; Ryu and Jacobson, 2012), and also reflects local changes in bedrock geology (Yde et al., 2005; Fransson et al., 2015). However, in absolute terms even the upper end of the alkalinity range reported in glacial discharge is very low compared to the volume-weighted average of Arctic rivers, $1048 \mu \mathrm{mol} \mathrm{kg}^{-1}$ (Cooper et al., 2008). In an Arctic context, meltwater is therefore relatively corrosive. In addition to low total alkalinity, glacier estuaries can exhibit undersaturation of $p \mathrm{CO}_{2}$ due to the non-linear effect of salinity on $p \mathrm{CO}_{2}$ (Rysgaard et al., 2012; Meire et al., 2015). This undersaturation arises even when the freshwater endmember is in equilibrium with atmospheric $p \mathrm{CO}_{2}$ and thus part of the $\mathrm{CO}_{2}$ drawdown observed in Arctic glacier estuaries is inorganic and not associated with primary production. In Godthåbsfjord this effect is estimated to account for $28 \%$ of total $\mathrm{CO}_{2}$ uptake within the fjord (Meire et al., 2015).

By decreasing the TA of glacially modified waters (Fig. 8), glacier discharge reduces the aragonite and calcite saturation states, thereby amplifying the effect of ocean acidification (Fransson et al., 2015, 2016; Ericson et al., 2019). High primary production can mitigate this impact as photosynthetic $\mathrm{CO}_{2}$ uptake reduces DIC and $p \mathrm{CO}_{2}$ (e.g. Fig. 9) in surface waters and increases the calcium carbonate saturation state (Chierici and Fransson, 2009; Rysgaard et al., 2012; Meire et al., 2015). In relatively productive fjords, the negative effect of TA dilution may therefore be counter balanced. However, in systems where discharge-driven stratification is responsible for low productivity, increased discharge may create a positive feedback on ocean acidification state in the coastal zone resulting in a lower saturation state of calcium carbonate (Chierici and Fransson, 2009; Ericson et al., 2019). 


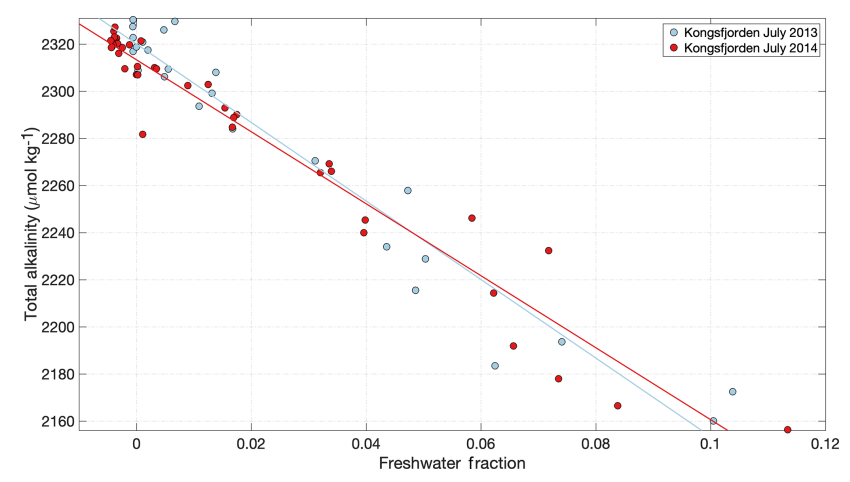

Figure 8. Total alkalinity in Kongsfjorden during the meltwater season (data from Fransson and Chierici, 2019). A decline in alkalinity is evident with increasing freshwater fraction in response to the low alkalinity concentrations in glacier discharge. Freshwater fraction was calculated using an average marine salinity endmember of 34.96; hence some slightly negative values are calculated in the outer fjord associated with the higher salinity of unmodified Atlantic water. Linear regression details are shown in Table S1.

Low-calcium carbonate saturation states $(\Omega<1$; i.e. corrosive conditions) have been observed in the inner part of Glacier Bay (Alaska), demonstrating that glaciers can amplify seasonal differences in the carbonate system and negatively affect the viability of shell-forming marine organisms (Evans et al., 2014). Low $\Omega A r$ has also been observed in the inner parts of Kongsfjorden, coinciding with high glacial discharge (Fransson et al., 2016). Such critically low $\Omega \mathrm{Ar}$ $(<1.4)$ conditions have negative effects on aragonite-shellforming calcifiers such as the pteropod Limacina helicina (Comeau et al., 2009, 2010; Lischka et al., 2011; Lischka and Riebesell, 2012; Bednaršek et al., 2014). Under future climate scenarios, in addition to the effect of increased glacier drainage in glacier fjords, synergistic effects with a combination of increased ocean $\mathrm{CO}_{2}$ uptake and warming will further amplify changes to the ocean acidification state (Fransson et al., 2016; Ericson et al., 2019), resulting in increasingly pronounced negative effects on calcium carbonate shell formation (Lischka and Riebesell, 2012).

\section{Organic matter in glacial discharge}

In addition to inorganic ions, glacial discharge also contains many organic compounds derived from biological activity on glacier surfaces and overridden sediments (Barker et al., 2006; Lawson et al., 2014b). Organic carbon stimulates bacterial activity, and remineralization of organic matter is a pathway to resupply labile nitrogen and phosphorous to microbial communities. Similar to macronutrient concentrations, DOM concentrations in glacial discharge are generally low (Table 2) compared to runoff from large Arctic rivers, which have DOM concentrations 1-2 orders of magnitude higher (Dittmar and Kattner, 2003; Le Fouest et al.,
2013). This is evidenced in Young Sound where dissolved organic carbon (DOC) concentrations increase with salinity in surface waters, demonstrating that glaciers are a relatively minor source of DOM to the fjord (Paulsen et al., 2017).

While DOM concentrations are low in glacial discharge, the bioavailability of this DOM is much higher than its marine counterpart (Hood et al., 2009; Lawson et al., 2014b; Paulsen et al., 2017). This is likely due to the low $\mathrm{C}: \mathrm{N}$ ratio of glacial DOM, as N-rich DOM of microbial origin is generally highly labile (Lawson et al., 2014a). It has been suggested that as glaciers retreat and the surrounding catchments become more vegetated, DOC concentrations in these catchments will increase (Hood and Berner, 2009; Csank et al., 2019). However, DOM from non-glacial terrestrial sources has a higher composition of aromatic compounds and thus is less labile (Hood and Berner, 2009; Csank et al., 2019). Furthermore, glacier coverage in watersheds is negatively correlated with DOC : DON ratios, so a reduction in the lability of DOM with less glacial coverage is also expected (Hood and Scott, 2008; Hood and Berner, 2009; Ren et al., 2019).

While DOC is sufficient to drive bacterial metabolism, bacteria also depend on nitrogen and phosphorus for growth. In this respect, bacteria are in direct competition with phytoplankton for macronutrients, and increasing additions of labile DOM downstream of glaciers could give bacteria a competitive edge. This would have important ecological consequences for the function of the microbial food web and the biological carbon sink (Larsen et al., 2015). Experiments with Arctic fjord communities, including Kongsfjorden, have shown that when bacteria are supplied with additional subsidies of labile carbon under nitrate limitation, they outcompete phytoplankton for nitrate (Thingstad et al., 2008; Larsen et al., 2015). This is even the case when there is an addition of excess $\mathrm{Si}$, which might be hypothesized to give diatoms a competitive advantage. The implications of such competition for the carbon cycle are however complicated by mixotrophy (Ward and Follows, 2016; Stoecker et al., 2017). An increasing number of primary producers have been shown to be able to simultaneously exploit inorganic resources and living prey, combining autotrophy and phagotrophy in a single cell. Mixotrophy allows protists to sustain photosynthesis in waters that are severely nutrient limited and provides an additional source of carbon as a supplement to photosynthesis. This double benefit decreases the dependence of primary producers on short-term inorganic nutrient availability. Moreover, mixotrophy promotes a shortened, and potentially more efficient, chain from nutrient regeneration to primary production (Mitra et al., 2014). Whilst mixotrophy is sparsely studied in Arctic glacier fjords, both increasing temperatures and stratification are expected to favour mixotrophic species (Stoecker and Lavrentyev, 2018), and thus an understanding of microbial food web dynamics is vital to predict the implications of increasing discharge on the carbon cycle in glacier fjord systems. 
Regardless of the high bioavailability of DOM from glacial discharge, once glacial DOM enters a fjord and is diluted by ocean waters, evidence of its uptake forming a significant component of the microbial food web in the Arctic has yet to be observed. Work from several outlet glacier fjords around Svalbard shows that the stable isotopic C ratio of bacteria does not match that of DOC originating from local glaciers, suggesting that glacially supplied DOC is a minor component of bacterial consumption compared to autochthonous carbon sources (Holding et al., 2017; Paulsen et al., 2018). Curiously, a data synthesis of taxonomic populations for glaciated catchments globally suggests a significant positive effect of glaciers on bacterial populations in glacier fjords but a negative effect in freshwaters and glacier forefields (Cauvy-Fraunié and Dangles, 2019). This suggests that multiple ecological and physical-chemical processes are at play, such that a simplistic argument that increasing glacial supply of DOC favours bacterial activity is moderated by other ecological factors. This is perhaps not surprising as different taxonomic groups may respond differently to perturbations from glacier discharge leading to changes in food web dynamics. For example, highly turbid glacial waters have particularly strong negative effects on filter-feeding (Arendt et al., 2011; Fuentes et al., 2016) and phagotrophic organisms (Sommaruga, 2015) and may also lead to reduced viral loads in the water column due to adsorption onto particle surfaces (Maat et al., 2019).

Whilst concentrations of DOM are low in glacier discharge, DOM-sourced nitrogen and phosphorous could still be relatively important in stratified outlet glacier fjords simply because inorganic nutrient concentrations are also low (e.g. Fig. 3). Refractory DON in rivers that is not directly degraded by bacteria can be subsequently broken down by photoammonification processes releasing ammonium (Xie et al., 2012). In large Arctic rivers, this nitrogen supply is greater than that supplied from inorganic sources (Le Fouest et al., 2013). For glacier discharge, processing of refractory DOM could potentially produce a comparable nitrogen flux to inorganic sources (Table 2, Wadham et al., 2016). Similarly, in environments where inorganic $\mathrm{PO}_{4}$ concentrations are low, DOP may be a relatively more important source of phosphorous for both bacteria and phytoplankton. Many freshwater and marine phytoplankton species are able to synthesize the enzyme alkaline phosphatase in order to efficiently utilize DOP (Hoppe, 2003; Štrojsová et al., 2005). In the context of stratified, low-salinity inner-fjord environments, where inorganic $\mathrm{PO}_{4}$ concentrations are potentially low enough to limit primary production (Prado-Fiedler, 2009), this process may be particularly important - yet DOP dynamics are understudied in glaciated catchments with limited data available (Stibal et al., 2009, Hawkings et al., 2016).

Finally, whilst DOC concentrations in glacier discharge are low, POC concentrations, which may also impact microbial productivity in the marine environment and contribute to the $\mathrm{C}$ sink within fjords, are less well characterized. Down- stream of Leverett Glacier, mean runoff POC concentrations are reported to be $43-346 \mu \mathrm{M}-5$ times higher than DOC (Lawson et al., 2014b). However, the opposite is reported for Young Sound, where DOC concentrations in three glacierfed streams were found to be 7-13 times higher than POC concentrations (Paulsen et al., 2017). Similarly, low POC concentrations of only $5 \mu \mathrm{M}$ were found in supraglacial discharge at Bowdoin glacier (Kanna et al., 2018). In summary, relatively little is presently known about the distribution, fate and bioavailability of POC in glaciated catchments.

\section{Insights into the long-term effects of glacier retreat}

Much of the present interest in Arctic ice-ocean interactions arises because of the accelerating increase in discharge from the Greenland Ice Sheet, captured by multi-annual to multidecadal time series (Bamber et al., 2018). This trend is attributed to atmospheric and oceanic warming due to anthropogenic forcing, at times enhanced by persistent shifts in atmospheric circulation (Box, 2002; Ahlström et al., 2017). From existing observations, it is clear that strong climate variability patterns are at play, such as the North Atlantic Oscillation/Arctic Oscillation, and that, in order to place recent change in context, time series exceeding the satellite era are required. Insight can be potentially gained from research into past sedimentary records of productivity from high-latitude marine and fjord environments. Records of productivity and the dominance of different taxa as inferred by microfossils, biogeochemical proxies and genetic records from those species that preserve well in sediment cores can help establish long-term spatial and temporal patterns around the present-day ice sheet periphery (Ribeiro et al., 2012). Around Greenland and Svalbard, sediment cores largely corroborate recent fjord-scale surveys suggesting that inner-fjord water column environments are generally low-productivity systems (Kumar et al., 2018), with protist taxonomic diversity and overall productivity normally higher in shelf waters than in inner-fjord environments (Ribeiro et al., 2017).

Several paleoclimate archives and numerical simulations suggest that the Arctic was warmer than today during the early to mid-Holocene thermal maximum $(\sim 8000$ years ago), which was registered by $\sim 1 \mathrm{~km}$ thinning of the Greenland Ice Sheet (Lecavalier et al., 2017). Multiproxy analyses performed on high-resolution and well-dated Holocene marine sediment records from contrasting fjord systems are therefore one approach to understand the nature of such past events, as these sediments simultaneously record climate and some long-term biotic changes representing a unique window into the past. However, while glacial-interglacial changes can provide insights into large-scale ice-ocean interactions and the long-term impact of glaciers on primary production, these timescales are of limited use to understanding more recent variability at the ice-ocean interface of fjord systems such as those mentioned in this review. The five well- 
characterized Arctic fjords used as case studies here (Fig. 1; Bowdoin, Kongsfjorden, Sermilik, Godthåbsfjord and Young Sound), for example, did not exist during the Last Glacial Maximum $\sim 19000$ years ago (Knutz et al., 2011).

On long timescales, glacier-ocean interactions are subject to marked temporal changes associated with glacialinterglacial cycles. In the short term, the position of glacier termini shifts inland during ice sheet retreat or outwards during ice sheet expansion, and in the long-term proglacial regions respond to isostatic uplift and delta progradation. The uplift of fine-grained glaciomarine and deltaic sediments is a notable feature of landscape development in fjord environments following the retreat of continental-scale ice sheets (Cable et al., 2018; Gilbert et al., 2018). This results in the gradual exposure and subsequent erosion of these sediment infills and their upstream floodplains, releasing labile organic matter to coastal ecosystems. Whilst the direct biogeochemical significance of such chemical fluxes may be limited in the marine environment on interannual timescales (Table 2), potentially more important is the Fe fertilization following wind erosion and dust emittance from glacial floodplains.

Ice core records from Greenland and Antarctica, spanning several climatic cycles, suggest that aeolian deposition rates at high latitudes were as much as 20 times greater during glacial than interglacial periods (Kohfeld and Harrison, 2001). Elevated input of terrigenous Fe during windy glacial episodes, and associated continental drying, has therefore been hypothesized to stimulate oceanic productivity through time and thus modify the oceanic and atmospheric $\mathrm{CO}_{2}$ balance (Martin, 1990). While there seems to be a pervasive dust-climate feedback on a glacial-interglacial planetary scale (Shaffer and Lambert, 2018), glacier retreat also exposes new areas of unconsolidated glacial sediments leading to an increase in both dust storm events and sediment yields from glacial basins locally. The spatial scale over which this glacially derived dust can be transported $(100-500 \mathrm{~km})$ far exceeds that of discharge-carried nutrients (Crusius et al., 2011; Prospero et al., 2012; Bullard, 2013).

\section{A need for new approaches?}

The pronounced temporal and spatial variations evident in the properties of glacially modified waters emphasize the need for high-resolution data on both short (hourly to daily) and long (seasonal to interannual) timescales in order to understand glacial processes and their downstream effects. In Godthåbsfjord, Juul-Pedersen et al. (2015) provide a detailed study of seasonal primary production dynamics. This monthly monitoring programme captures seasonal, annual and interannual trends in the magnitude of primary production. Whilst such a time series clearly highlights a strong interannual stability in both seasonal and annual primary production (103.7 $\pm 17.8 \mathrm{~g} \mathrm{C} \mathrm{m}^{-2} \mathrm{yr}^{-1}$; Juul-Pedersen et al., 2015), it is unable to fully characterize shorter (i.e. days to weeks) timescale events such as the spring bloom period. Yet higher data resolution cannot feasibly be sustained by shipboard campaigns.

Low-frequency, high-discharge events are known to occur in Godthåbsfjord, and other glacier fjords (Kjeldsen et al., 2014), but are challenging to observe from monthly resolution data, and thus there is sparse data available to quantify their occurrence and effects or to quantify the shortterm variation in discharge rates at large, dynamic marineterminating glaciers. Consequently, modelled subglacial discharge rates and glacier discharge derived from regional models (e.g. RACMO, Noël et al., 2015), which underpin our best-available estimates of the subglacial nutrient pump (e.g. Carroll et al., 2016), do not yet consider such variability. Time lapse imagery shows that the lifetimes and spatial extents of subglacial discharge plumes can vary considerably (Schild et al., 2016; Fried et al., 2018). While buoyant plume theory has offered important insights into the role of subglacial plumes in the nutrient pump, buoyant plume theory does not characterize the lateral expansion of plume waters. Furthermore, determining the influence of discharge, beyond the immediate vicinity of glacial outflows, is a Lagrangian exercise, yet the majority of existing observational and modelling studies have been conducted primarily in the Eulerian reference frame (e.g. ship-based profiles and moored observations that describe the water column at a fixed location). Moving towards an observational Lagrangian framework will require the deployment of new technology such as the recent development of low-cost GPS trackers which, especially when combined with in situ sensors, may improve our understanding of the transport and mixing of heat, freshwater, sediment and nutrients downstream of glaciers (Carlson et al., 2017; Carlson and Rysgaard, 2018). For example, GPS trackers deployed on "bergy bits" have revealed evidence of small-scale, retentive eddies in Godthåbsfjord (Carlson et al., 2017) and characterized the surface flow variability in Sermilik Fjord (Sutherland et al., 2014).

Unmanned aerial vehicles and autonomous surface/underwater vehicles can also be used to observe the spatio-temporal variability of subglacial plumes at high resolution (Mankoff et al., 2016; Jouvet et al., 2018). Complementing these approaches are developments in the rapidly maturing field of miniaturized chemical sensors suitable for use in cryosphere environments (Beaton et al., 2012). Such technology will ultimately reduce much of the uncertainty associated with glacier-ocean interactions by facilitating more comprehensive, more sustainable field campaigns (Straneo et al., 2019), with reduced costs and environmental footprints (Nightingale et al., 2015; Grand et al., 2017, 2019). This is evidenced by a successful prolonged mooring deployment in the Santa Inés Glacier fjord system (Fig. 9).

The Santa Inés Glacier fjord sits adjacent to the open water of the Straits of Magellan in southwest Patagonia. Moored high-resolution measurements are now collected in situ us- 

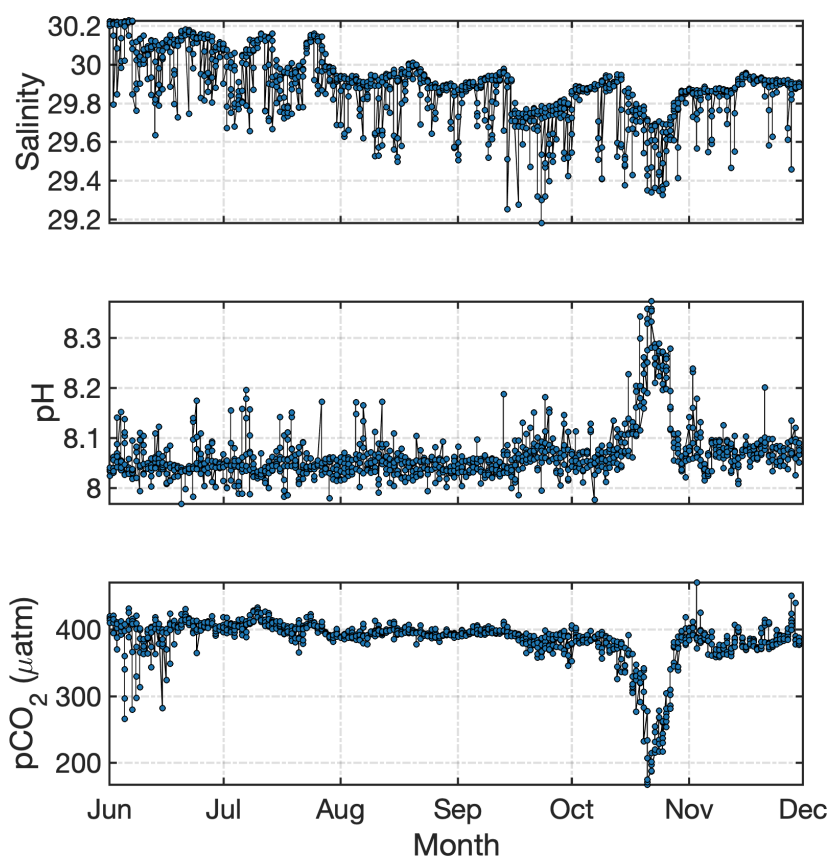

Figure 9. Winter-spring dynamics of salinity, $\mathrm{pH}$ and $p \mathrm{CO}_{2}$ at the Santa Inés Glacier fjord, Ballena (Patagonia). High-resolution $p \mathrm{CO}_{2}$ and $\mathrm{pH}$ measurements (every three hours) were taken in situ using autonomous SAMI-CO $\mathrm{C}_{2}$ and SAMI-pH sensors (as per Vergara-Jara et al., 2019) (Sunburst Sensors, LLC) starting in the austral autumn (March 2018). All sensors were moored at $10 \mathrm{~m}$ depth.

ing sensor technology and a mooring within the fjord. Measurements include the carbonate system parameters $p \mathrm{CO}_{2}$ and $\mathrm{pH}$. The 2018 winter to spring time series (Fig. 9) demonstrates a sharp decline in $p \mathrm{CO}_{2}$ and corresponding increase in $\mathrm{pH}$, associated with the onset of the spring bloom in early October. Such a pronounced event, occurring over $\sim 2$ weeks, would be impossible to characterize fully with monthly sampling of the fjord. Over winter, $\mathrm{pH}$ and $p \mathrm{CO}_{2}$ were more stable, but sensor salinity data still reveal shortterm dynamics within the fjords' surface waters (Fig. 9). A general decline in salinity is evident moving from winter into spring. Short-term changes on diurnal timescales - presumably linked to tidal forcing - and also on daily-weekly timescales - possibly linked to weather patterns - are also evident (Fig. 9). Much work remains to be done to deduce the role of these short-term drivers on primary production.

Finally, we note that the different scales over which the processes discussed herein operate raises the critical question of how importantly the different effects of glacial discharge on the marine environment are perceived in different research fields. Herein we have largely focused on localto regional-scale processes operating on seasonal to interannual timescales in the marine environment at individual field sites (Fig. 1). A very different emphasis may have been placed on the relative importance of different processes if a different spatial/temporal perspective had been adopted, for

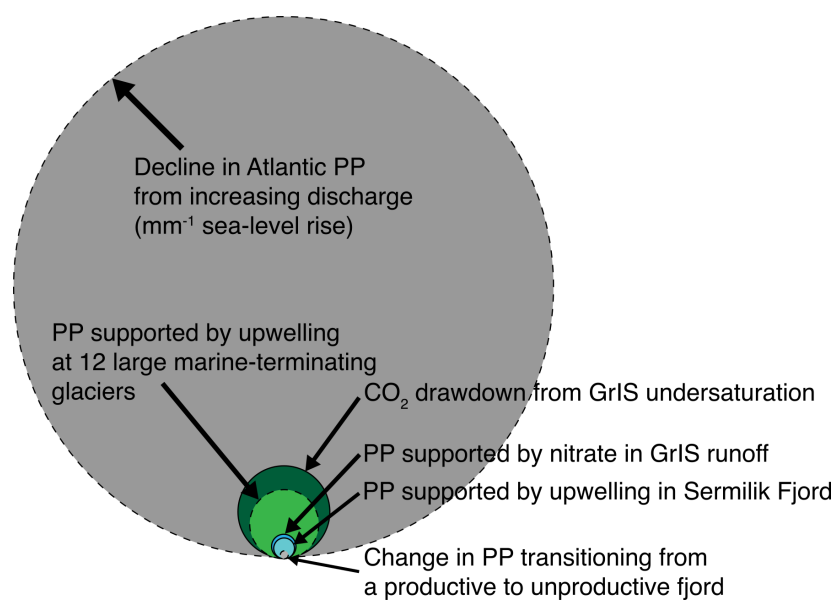

Figure 10. A scale comparison of the significance of different chemical/physical processes driven by glacial discharge in terms of the resulting effects on annual marine primary production (PP) or $\mathrm{CO}_{2}$ drawdown (units $\mathrm{Tg} \mathrm{C} \mathrm{yr}^{-1}$ ). Bold lines indicate mean estimates based on multiple independent studies; dashed lines are based on only one. Green-blue colours are positive; grey colours are negative. Calculated changes (largest-smallest) are determined from glacial discharge superimposed on a modelled global RCP8.5 scenario (Kwiatkowski et al., 2019), $p \mathrm{CO}_{2}$ uptake due to meltwaterinduced undersaturation scaled to the Greenland Ice Sheet (Meire et al., 2015), computed upwelled $\mathrm{NO}_{3}$ fluxes (assuming $100 \%$ utilization at Redfield ratio, Hopwood et al., 2018), mean freshwater $\mathrm{NO}_{3}$ (Greenland) inventory (Table 3), $\mathrm{NO}_{3}$ anomaly due to upwelling in Sermilik Fjord (Cape et al., 2019), and contrasting the mean PP for groups II and IV (Table 1) for a fjord the size of Young Sound.

example considering the decadal-centennial effects of increasing meltwater addition to the Atlantic Ocean, or conversely the seasonal effect of meltwater solely within terrestrial systems. One conceptual way of comparing some of the different processes and effects occurring as a result of glacial discharge is to consider a single biogeochemical cycle on a global scale, for example the carbon drawdown associated with marine primary production (Fig. 10).

A net decrease in primary production is predicted over the 21 st century at the Atlantic scale on the order of $>$ $60 \mathrm{Tg} \mathrm{Cyr}^{-1} \mathrm{~mm}^{-1}$ of annual sea-level rise from Greenland due solely to the physical effects of freshwater addition (Kwiatkowski et al., 2019). An example of a potential negative effect on primary production operating on a much smaller scale would be the retreat of marineterminating glaciers and the associated loss of $\mathrm{NO}_{3}$ upwelling (Torsvik et al., 2019). The effect of switching a modest glacier fjord the size of Young Sound from being a higherproductivity marine-terminating glacier fjord environment to a low-productivity glacier fjord environment receiving runoff only from land-terminating glaciers (using mean primary production values from Table 1) would be a change of $\sim 0.01 \mathrm{Tg} \mathrm{Cyr}^{-1}$. Conversely, potential positive effects of glacier discharge on primary production can be estimated us- 
ing the Redfield ratio (Redfield, 1934) to approximate how much primary production could be supported by $\mathrm{NO}_{3}$ supplied to near-surface waters from meltwater-associated processes. Adding all the $\mathrm{NO}_{3}$ in freshwater around Greenland (Table 3) into the ocean, in the absence of any confounding physical effects from stratification, would be equivalent to primary production of $\sim 0.09 \mathrm{Tg} \mathrm{Cyr}^{-1}$. Using the same arbitrary conversion to scale other fluxes, the primary production potentially supported by upwelling of $\mathrm{NO}_{3}$ at Sermilik (Cape et al., 2019) is approximately $0.13 \mathrm{Tg} \mathrm{C} \mathrm{yr}^{-1}$ and that supported by upwelling of $\mathrm{NO}_{3}$ at 12 large Greenlandic marine-terminating systems (Hopwood et al., 2018) is approximately $1.3 \mathrm{Tg} \mathrm{Cyr}^{-1}$. Finally the inorganic $\mathrm{CO}_{2}$ drawdown due to $p \mathrm{CO}_{2}$ undersaturation in glacier estuaries around Greenland is approximately $1.8 \mathrm{Tg} \mathrm{Cyr}^{-1}$ (Meire et al., 2015).

These values provide a rough conceptual framework for evaluating the relative importance of different processes operating in parallel but on different spatial scales (Fig. 10). Whilst a discussion of glacial weathering processes is beyond the scope of this review, we note that these estimates of annual C fluxes (Fig. 10) are comparable to, or larger than, upper estimates of the $\mathrm{CO}_{2}$ drawdown/release associated with weathering of carbonate, silicate and sulfide minerals in glaciated catchments globally (Jones et al., 2002; Tranter et al., 2002; Torres et al., 2017). The implication of this is that shifts in glacier-ocean inter-connectivity could be important compared to changes in weathering rates in glaciated catchments in terms of feedbacks in the $\mathrm{C}$ cycle on interannual timescales.

\subsection{A link between retreating glaciers and harmful algal blooms?}

Shifts between different microbial groups in the ocean can have profound implications for ecosystem services. For example, addition of DOM can induce shifts in the microbial loop to favour bacteria in their competition with phytoplankton for macronutrient resources, which directly affects the magnitude of $\mathrm{CO}_{2}$ uptake by primary producers (Thingstad et al., 2008; Larsen et al., 2015). Similarly, changing the availability of $\mathrm{Si}$ relative to other macronutrients affects the viability of diatom growth and thus, due to the efficiency with which diatom frustules sink, potentially the efficiency of the biological carbon pump (Honjo and Manganini, 1993; Dugdale et al., 1995).

A particularly concerning hypothesis, recently proposed from work across Patagonian fjord systems and the first evaluations of harmful algal bloom (HAB)-associated species around Greenland, is that changes in glacier discharge and associated shifts in stratification and temperature could affect HAB occurrence (Richlen et al., 2016; León-Muñoz et al., 2018; Joli et al., 2018). In the Arctic, very little work has been done to specifically investigate HAB occurrence and drivers in glacier-discharge-affected regions. Yet HAB- associated species are known to be present in Arctic waters (Lefebvre et al., 2016; Richlen et al., 2016), including Alexandrium tamarense, which has been implicated as the cause of toxin levels exceeding regulatory limits in scallops from west Greenland (Baggesen et al., 2012), and Alexandrium fundyense, cysts of which have been found at low concentrations in Disko Bay (Richlen et al., 2016). Around Greenland, low temperatures are presently thought to be a major constraint on HAB development (Richlen et al., 2016). Yet increasing meltwater discharge into coastal regions drives enhanced stratification and thus directly facilitates the development of warm surface waters through summer. This meltwater-driven stratification has been linked to the occurrence of HAB species including the diatoms Pseudonitzschia spp. (Joli et al., 2018). Thus, increasing freshwater discharge from Greenland could increase HAB viability in downstream stratified marine environments (Richlen et al., 2016; Joli et al., 2018; Vandersea et al., 2018), potentially with negative impacts on inshore fisheries.

Given the ongoing intensification of climate change and the interacting effects of different environmental drivers of primary production in glacier fjord systems (e.g. surface warming, carbonate chemistry, light availability, stratification, nutrient availability and zooplankton distribution), it is however very challenging to predict future changes on HAB event frequency and intensity. Furthermore, different HAB-associated groups (e.g. toxin-producing diatom and flagellate species) may show opposite responses to the same environmental perturbation (Wells et al., 2015). Moreover, many known toxin-producing species in the Arctic are mixotrophic, further complicating their interactions with other microbial groups (Stoecker and Lavrentyev, 2018). Fundamental knowledge gaps clearly remain concerning the mechanisms of HAB development, and there are practically no time series or studies to date investigating changes specifically in glaciated Arctic catchments. Given the socioeconomic importance of glacier-fjord-scale subsistence fisheries, especially around Greenland, one priority for future research in the Arctic is to establish to what extent HABassociated species are likely to benefit from future climate scenarios in regions where freshwater runoff is likely to be subject to pronounced ongoing changes (Baggesen et al., 2012; Richlen et al., 2016; Joli et al., 2018).

\section{Understanding the role of glaciers alongside other manifestations of climate change}

In order to comprehensively address the questions posed in this review, it is evident that a broader perspective than a narrow focus on freshwater discharge alone, and its regional biogeochemical effects, is required (Fig. 10). Freshwater discharge is not the sole biogeochemical connection between the glaciers and the ocean (Fig. 11). Dust plumes from proglacial terrain supply glacial flour to the ocean on scales 


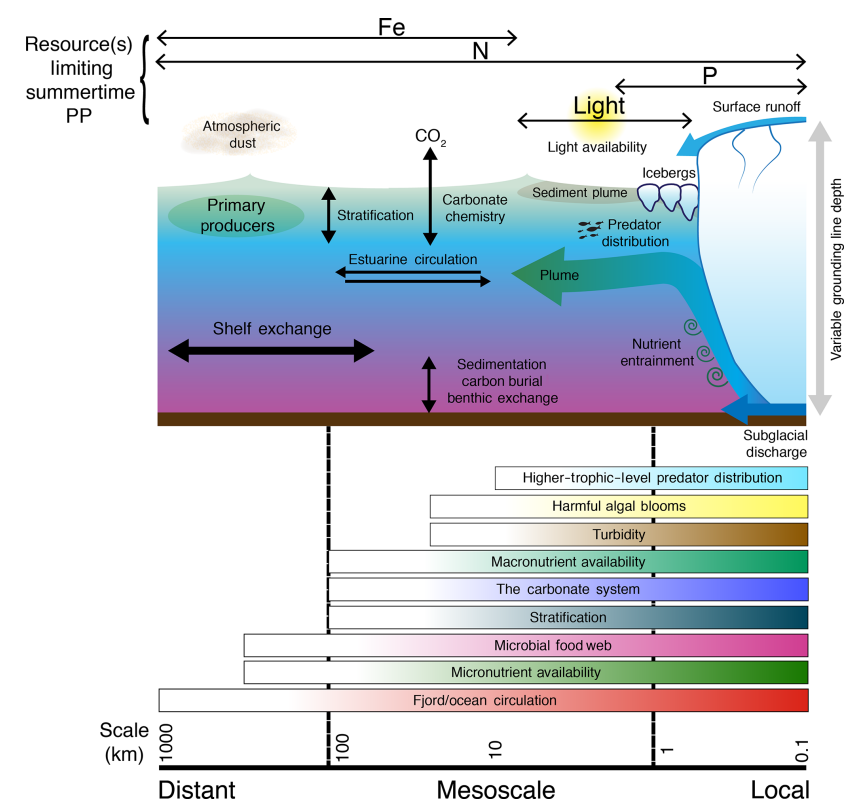

Figure 11. The approximate spatial scale over which glaciers directly affect different drivers of marine primary production (PP) compared to the likely limiting resources constraining primary production.

of $>100 \mathrm{~km}$ and thus act as an important source of Fe to the ocean at high latitudes, where other atmospheric dust sources are scarce (Prospero et al., 2012; Bullard, 2013). Similarly, icebergs have long been speculated to act as an important source of Fe to the offshore ocean (Hart, 1934; Raiswell et al., 2008; Lin et al., 2011) and induce mixing of the surface ocean (Helly et al., 2011; Carlson et al., 2017). Whilst freshwater discharge is a driver of biogeochemical changes in nearshore and fjord environments downstream of glaciers (Arimitsu et al., 2016), the distant (>100 km scale) biogeochemical effects of glaciers on the marine environment are likely dominated by these alternative mechanisms (Fig. 11). Furthermore, the distal physical effects of adding increasingly large volumes of glacier discharge into the Atlantic may have biogeochemical feedbacks which, whilst poorly studied, are potentially far larger than individual regionalscale processes discussed herein (Fig. 10) (Kwiatkowski et al., 2019).

Discharge-derived effects must also be interpreted in the context of other controls on primary production in the highlatitude marine environment. Sea-ice properties, and particularly the timing of its breakup and the duration of the ice-free season, are a key constraint on the seasonal trend in primary production in the Arctic (Rysgaard et al., 1999; Rysgaard and Glud, 2007). Similarly, whilst discharge affects multiple aspects of the three-dimensional water column including fjord-scale circulation and mixing (Kjeldsen et al., 2014; Carroll et al., 2017), stratification (Meire et al., 2016b; Oliver et al., 2018), and boundary current properties (Sutherland et al., 2009), other changes in the Earth system including wind patterns (Spall et al., 2017; Sundfjord et al., 2017; Le Bras et al., 2018), sea-ice dynamics, regional temperature increases (Cook et al., 2016), and other freshwater sources (Benetti et al., 2019) are driving changes in these parameters on similar spatial and temporal scales (Stocker et al., 2013; Hop et al., 2019).

Several key uncertainties remain in constraining the role of glaciers in the marine biogeochemical system. Outlet glacier fjords are challenging environments in which to gather data, and there is a persistent deficiency of both physical and biogeochemical data within kilometres of large marine-terminating glacier systems, where glacier discharge first mixes with ocean properties. Subglacial discharge plume modelling and available data from further downstream can to some extent evade this deficiency for conservative physical (e.g. salinity and temperature) and chemical (e.g. noble gases, $\mathrm{NO}_{3}$ and $\mathrm{PO}_{4}$ ) parameters in order to understand mixing processes (Mortensen et al., 2014; Carroll et al., 2017; Beaird et al., 2018). However, the mixing behaviour of nonconservative chemical parameters (e.g. $\mathrm{pH}, \mathrm{Si}$, and $\mathrm{Fe}$ ) is more challenging to deduce from idealized models. Furthermore, the biogeochemical effects of low-frequency, highdischarge events and small-scale mixing, such as that induced around icebergs, remain largely unknown. There is a critical need to address this deficiency by the deployment of new technology to study marine-terminating glacier mixing zones and downstream environments.

The uniqueness of individual glacier fjord systems, due to highly variable fjord circulation and geometry, is itself a formidable challenge in scaling up results from Arctic field studies to produce a process-based understanding of glacier-ocean interactions. A proposed solution, which works equally well for physical, chemical and biological perspectives, is to focus intensively on a select number of key field sites at the land-ocean interface rather than mainly on large numbers of broadscale, summertime-only surveys (Straneo et al., 2019). In addition to facilitating long-term time series, focusing in detail on fewer systems facilitates greater seasonal coverage to understand the changes in circulation and productivity that occur before, during and after the melt season. However, the driving rationale for the selection of key glacier field sites to date was in many cases their contribution to sea-level rise. Thus, well-studied sites account for a large fraction of total Arctic glacier discharge into the ocean but only represent a small fraction of the glaciated coastline. For example, around the Greenland coastline, the properties of over 200 marine-terminating glaciers are characterized (Morlighem et al., 2017). Yet just 5 glaciers (including Helheim in Sermilik Fjord) account for $30 \%$ of annual combined meltwater and ice discharge from Greenland, and 15 account for $>50 \%$ (year 2000 data, Enderlin et al., 2014). The relative importance of individual glaciers changes when considering longer time periods (e.g. 1972-2018, Mouginot et al., 2019), yet, irrespective 
of the timescale considered, a limited number of glaciers account for a large fraction of annual discharge. Jakobshavn Isbræ and Kangerlussuaq, for example, are among the largest four contributors to ice discharge around Greenland over both historical (1972-2018) and recent (2000-2012) time periods (Enderlin et al., 2014; Mouginot et al., 2019). Whilst small glaciated catchments, such as Kongsfjorden and Young Sound, are far less important for sea-level rise, similar "small" glaciers occupy a far larger fraction of the high-latitude coastline and are thus more representative of glaciated coastline habitat.

\section{Conclusions}

\subsection{Where and when does glacial freshwater discharge promote or reduce marine primary production?}

In the Arctic, marine-terminating glaciers are associated with the enhanced vertical fluxes of macronutrients, which can drive summertime phytoplankton blooms throughout the meltwater season.

In the Arctic, land-terminating glaciers are generally associated with the local suppression of primary production, due to light limitation and stratification impeding vertical nutrient supply from mixing. Primary production in Arctic glacier fjords without marine-terminating glaciers is generally low compared to other coastal environments.

In contrast to the Arctic, input of Fe from glaciers around the Southern Ocean is anticipated to have a positive effect on marine primary production, due to the extensive limitation of primary production by $\mathrm{Fe}$.

In some brackish, inshore waters, DOM from glaciated catchments could enhance bacterial activity at the expense of phytoplankton, but a widespread effect is unlikely due to the low DOM concentration in freshwater.

Glacier discharge reduces the buffering capacity of glacially modified waters and amplifies the negative effects of ocean acidification, especially in low-productivity systems, which negatively affects calcifying organisms.

\subsection{How does spatio-temporal variability in glacial discharge affect marine primary production?}

Glacier retreat associated with a transition from marine- to land-terminating systems is expected to negatively affect downstream productivity in the Arctic, with long-term inland retreat also changing the biogeochemical composition of freshwater.

Low-frequency, high-discharge events are speculated to be important drivers of physical and biogeochemical processes in the marine environment, but their occurrence and effects are poorly constrained.

$\mathrm{HAB}$ viability may increase in future Arctic glacier fjords in response to increasing discharge driving enhanced strati- fication, but there are very limited data available to test this hypothesis.

A time series in Godthåbsfjord suggests that, on interannual timescales, fjord-scale primary production is relatively stable despite sustained increases in glacier discharge.

\subsection{How far-reaching are the effects of glacial discharge on marine biogeochemistry?}

Local effects of glaciers (within a few kilometres of the terminus, or within glacier fjords) include light suppression, impediment of filter-feeding organisms and influencing the foraging habits of higher organisms.

Mesoscale effects of glaciers (extending tens to hundreds of kilometres from the terminus) include nutrient upwelling, Fe enrichment of seawater, modification of the carbonate system (both by physical and biological drivers) and enhanced stratification.

Remote effects are less certain. Beyond the $10-100 \mathrm{~km}$ scale over which discharge plumes can be evident, other mechanisms of material transfer between glaciers and the ocean, such as atmospheric deposition of glacial flour and icebergs, are likely more important than meltwater (Fig. 11). Fully coupled biogeochemical and physical global models will be required to fully assess the impacts of increasing discharge into the ocean on a pan-Atlantic scale (Fig. 10).

Data availability. Data sources are cited within the text. For primary production data, see Andersen (1977), Nielsen and Hansen (1995), Jensen et al. (1999), Nielsen (1999), Levinsen and Nielsen (2002), Juul-Pedersen et al. (2015), Meire et al. (2017), Lund-Hansen et al. (2018), Hop et al. (2002), Iversen and Seuthe (2011), Hodal et al. (2012), van de Poll et al. (2018), Seifert et al. (2019), Smoła et al. (2017), Rysgaard et al. (1999), Holding et al. (2019), Harrison et al. (1982), and Reisdorph and Mathis (2015). For chemical data and associated fluxes, see Fransson et al. (2016), van de Poll et al. (2018), Cantoni et al. (2019), Cauwet and Sidorov (1996), Emmerton et al. (2008), Hessen et al. (2010), Hopwood et al. (2016, 2017, 2018), Kanna et al. (2018), Cape et al. (2019), Hawkings et al. (2014, 2017), Lund-Hansen et al. (2018), Meire et al. (2015, 2016a), Brown et al. (2010), Paulsen et al. (2017), Stevenson et al. (2017), Statham et al. (2008), Bhatia et al. (2010, 2013a, 2013b), Lawson et al. (2014b), Hood et al. (2015), Csank et al. (2019), Wadham et al. (2016), Achterberg et al. (2018), Marsay et al. (2017), Annett et al. (2017), Ducklow et al. (2017), Tonnard et al. (2020), Lippiatt et al. (2010), Fransson and Chierici (2019), Vergara-Jara et al. (2019), and Kwiatkowski et al. (2019). For discharge plume properties, see Carroll et al. (2016), Halbach et al. (2019), Kanna et al. (2018), Mankoff et al. (2016), Meire et al. (2016b), Jackson et al. (2017), Bendtsen et al. (2015), Beaird et al. (2018), and Schaffer et al. (2020).

Supplement. The supplement related to this article is available online at: https://doi.org/10.5194/tc-14-1347-2020-supplement. 
Author contributions. TD coordinated workshop activities and designed questions to structure the review paper. MJH coordinated manuscript writing. All authors contributed to writing at least one section of the review and assisted with the revision of other sections. DC edited all figures.

Competing interests. The authors declare that they have no conflict of interest.

Acknowledgements. The authors thank all conveners and participants of the IASC cross-cutting activity "The importance of Arctic glaciers for the Arctic marine ecosystem" hosted by the Cryosphere Working Group/Network on Arctic Glaciology and the Marine Working Group. IASC funding to support early career scientist attendance is gratefully acknowledged. Figure 7 and all linear regressions were produced in SigmaPlot.

Financial support. Mark Hopwood was financed by the DFG (award number HO 6321/1-1). Andy Hodson was supported by Joint Programming Initiative (JPI-Climate Topic 2: Russian Arctic and Boreal Systems) award 71126 and Research Council of Norway grant 294764. Johnna Holding was supported by Marie Curie grant GrIS-Melt (752325). Lorenz Meire was supported by the VENI program from the Dutch Research Council (NWO grant 016.Veni.192.150). José L. Iriarte received support from the FONDECYT 1170174 project. Sofia Ribeiro received support from Geocenter Denmark (project GreenShift). Thorben Dunse was supported by the Nordforsk-funded project (GreenMAR).

The article processing charges for this open-access publication were covered by a Research

Centre of the Helmholtz Association.

Review statement. This paper was edited by Evgeny A. Podolskiy and reviewed by Jon Hawkings and Kiefer Forsch.

\section{References}

Achterberg, E. P., Steigenberger, S., Marsay, C. M., Lemoigne, F. A. C., Painter, S. C., Baker, A. R., Connelly, D. P., Moore, C. M., Tagliabue, A., and Tanhua, T.: Iron Biogeochemistry in the High Latitude North Atlantic Ocean, Sci. Rep., 8, 1283, https://doi.org/10.1038/s41598-018-19472-1, 2018.

Ahlstrøm, A. P., Petersen, D., Langen, P. L., Citterio, M., and Box, J. E.: Abrupt shift in the observed runoff from the southwestern Greenland ice sheet, Sci. Adv., 3, e1701169, https://doi.org/10.1126/sciadv.1701169, 2017.

Andersen, O. G. N.: Primary production, illumination and hydrography in Jørgen Brønlund Fjord, North Greenland, in: Meddelelser om Grønland, Nyt Nordisk Forlag, København, 1977.

Annett, A. L., Skiba, M., Henley, S. F., Venables, H. J., Meredith, M. P., Statham, P. J., and Ganeshram, R. S.: Comparative roles of upwelling and glacial iron sources in Ryder Bay, coastal western Antarctic Peninsula, Mar. Chem., 176, 21-33, https://doi.org/10.1016/j.marchem.2015.06.017, 2015.

Annett, A. L., Fitzsimmons, J. N., Séguret, M. J. M., Lagerström, M., Meredith, M. P., Schofield, O., and Sherrell, R. M.: Controls on dissolved and particulate iron distributions in surface waters of the Western Antarctic Peninsula shelf, Mar. Chem., 196, 8197, https://doi.org/10.1016/j.marchem.2017.06.004, 2017.

Arendt, K. E., Nielsen, T. G., Rysgaard, S., and Tonnesson, K.: Differences in plankton community structure along the Godthabsfjord, from the Greenland Ice Sheet to offshore waters, Mar. Ecol. Prog. Ser., 401, 49-62, https://doi.org/10.3354/meps08368, 2010.

Arendt, K. E., Dutz, J., Jonasdottir, S. H., Jung-Madsen, S., Mortensen, J., Moller, E. F., and Nielsen, T. G.: Effects of suspended sediments on copepods feeding in a glacial influenced sub-Arctic fjord, J. Plankton Res., 33, 1526-1537, https://doi.org/10.1093/plankt/fbr054, 2011.

Arendt, K. E., Juul-Pedersen, T., Mortensen, J., Blicher, M. E., and Rysgaard, S.: A 5-year study of seasonal patterns in mesozooplankton community structure in a subArctic fjord reveals dominance of Microsetella norvegica (Crustacea, Copepoda), J. Plankton Res., 35, 105-120, https://doi.org/10.1093/plankt/fbs087, 2013.

Arimitsu, M. L., Piatt, J. F., Madison, E. N., Conaway, J. S., and Hillgruber, N.: Oceanographic gradients and seabird prey community dynamics in glacial fjords, Fish. Oceanogr., 21, 148-169, https://doi.org/10.1111/j.1365-2419.2012.00616.x, 2012.

Arimitsu, M. L., Piatt, J. F., and Mueter, F.: Influence of glacier runoff on ecosystem structure in Gulf of Alaska fjords, Mar. Ecol. Prog. Ser., 560, 19-40, https://doi.org/10.3354/meps11888, 2016.

Arrigo, K. R. and van Dijken, G. L.: Continued increases in Arctic Ocean primary production, Prog. Oceanogr., 136, 60-70, https://doi.org/10.1016/j.pocean.2015.05.002, 2015.

Arrigo, K. R., van Dijken, G. L., Castelao, R. M., Luo, H., Rennermalm, Å. K., Tedesco, M., Mote, T. L., Oliver, H., and Yager, P. L.: Melting glaciers stimulate large summer phytoplankton blooms in southwest Greenland waters, Geophys. Res. Lett., 44, 6278-6285, https://doi.org/10.1002/2017GL073583, 2017.

Azetsu-Scott, K. and Syvitski, J. P. M.: Influence of melting icebergs on distribution, characteristics and transport of marine particles in an East Greenland fjord, J. Geophys. Res., 104, 5321, https://doi.org/10.1029/1998JC900083, 1999.

Baggesen, C., Moestrup, Ø., and Daugbjer N.: Molecular phylogeny and toxin profiles of Alexandrium tamarense (Lebour) Balech (Dinophyceae) from the west coast of Greenland, Harmful Algae, 19, 108-116, https://doi.org/10.1016/j.hal.2012.06.005, 2012.

Bamber, J. L., Tedstone, A. J., King, M. D., Howat, I. M., Enderlin, E. M., van den Broeke, M. R., and Noel, B.: Land Ice Freshwater Budget of the Arctic and North Atlantic Oceans: 1. Data, Methods, and Results, J. Geophys. Res.-Ocean., 123, 1827-1837, https://doi.org/10.1002/2017JC013605, 2018.

Barker, J. D., Sharp, M. J., Fitzsimons, S. J., and Turner, R. J.: Abundance and dynamics of dissolved organic carbon in glacier systems, Arct. Antarct. Alp. Res., 38, 163-172, https://doi.org/10.1657/15230430(2006)38[163:aadodo]2.0.co;2, 2006. 
Beaird, N. L., Straneo, F., and Jenkins, W.: Export of strongly diluted Greenland meltwater from a major glacial fjord, Geophys. Res. Lett., 43, 4163-4170, https://doi.org/10.1029/2018GL077000, 2018.

Beaton, A. D., Cardwell, C. L., Thomas, R. S., Sieben, V. J., Legiret, F. E., Waugh, E. M., Statham, P. J., Mowlem, M. C., and Morgan, H.: Lab-on-Chip Measurement of Nitrate and Nitrite for In Situ Analysis of Natural Waters, Environ. Sci. Technol., 46, 95489556, https://doi.org/10.1021/es300419u, 2012.

Bednaršek, N., Tarling, G. A., Bakker, D. C. E., Fielding, S., and Feely, R. A.: Dissolution Dominating Calcification Process in Polar Pteropods Close to the Point of Aragonite Undersaturation, PLoS One, 9, e109183, https://doi.org/10.1371/journal.pone.0109183, 2014.

Bendtsen, J., Mortensen, J., and Rysgaard, S.: Seasonal surface layer dynamics and sensitivity to runoff in a high Arctic fjord (Young Sound/Tyrolerfjord, $74^{\circ} \mathrm{N}$ ), J. Geophys. Res.-Ocean., 119, 6461-6478, https://doi.org/10.1002/2014JC010077, 2014.

Bendtsen, J., Mortensen, J., Lennert, K., and Rysgaard, S.: Heat sources for glacial ice melt in a west Greenland tidewater outlet glacier fjord: The role of subglacial freshwater discharge, Geophys. Res. Lett., 42, 4089-4095, https://doi.org/10.1002/2015GL063846, 2015.

Benetti, M., Reverdin, G., Clarke, J. S., Tynan, E., Holliday, N. P., Torres-Valdes, S., Lherminier, P., and Yashayaev, I.: Sources and distribution of fresh water around Cape Farewell in 2014, J. Geophys. Res.-Ocean., 124, 9404-9416, https://doi.org/10.1029/2019JC015080, 2019.

Bhatia, M. P., Kujawinski, E. B., Das, S. B., Breier, C. F., Henderson, P. B., and Charette, M. A.: Greenland meltwater as a significant and potentially bioavailable source of iron to the ocean, Nat. Geosci., 6, 274-278, https://doi.org/10.1038/ngeo1746, 2013a.

Bhatia, M. P., Das, S. B., Xu, L., Charette, M. A., Wadham, J. L., and Kujawinski, E. B.: Organic carbon export from the Greenland ice sheet, Geochim. Cosmochim. Acta, 109, 329-344, https://doi.org/10.1016/j.gca.2013.02.006, 2013b.

Bhatia, M. P., Das, S. B., Longnecker, K., Charette, M. A., and Kujawinski, E. B.: Molecular characterization of dissolved organic matter associated with the Greenland ice sheet, Geochim. Cosmochim. Acta, 74, 3768-3784, https://doi.org/10.1016/j.gca.2010.03.035, 2010.

Blain, S., Treguer, P., Belviso, S., Bucciarelli, E., Denis, M., Desabre, S., Fiala, M., Jezequel, V. M., Le Fevre, J., Mayzaud, P., Marty, J. C., and Razouls, S.: A biogeochemical study of the island mass effect in the context of the iron hypothesis: Kerguelen Islands, Southern Ocean, Deep. Res. Part I, 48, 163-187, 2001.

Bliss, A., Hock, R., and Radić, V.: Global response of glacier runoff to twenty-first century climate change, J. Geophys. Res.-Earth Surf., 119, 717-730, 2014.

Boone, W., Rysgaard, S., Carlson, D. F., Meire, L., Kirillov, S., Mortensen, J., Dmitrenko, I., Vergeynst, L., and Sejr, M. K.: Coastal Freshening Prevents Fjord Bottom Water Renewal in Northeast Greenland: A Mooring Study From 2003 to 2015, Geophys. Res. Lett., 45, 2726-2733, https://doi.org/10.1002/2017GL076591, 2018.

Bowie, A. R., van der Merwe, P., Quéroué, F., Trull, T., Fourquez, M., Planchon, F., Sarthou, G., Chever, F., Townsend, A. T., Obernosterer, I., Sallée, J.-B., and Blain, S.: Iron budgets for three distinct biogeochemical sites around the Kerguelen Archipelago
(Southern Ocean) during the natural fertilisation study, KEOPS2, Biogeosciences, 12, 4421-4445, https://doi.org/10.5194/bg12-4421-2015, 2015.

Box, J. E.: Survey of Greenland instrumental temperature records: 1873-2001, Int. J. Climatol., 22, 1829-1847, https://doi.org/10.1002/joc.852, 2002.

Boyle, E. A., Edmond, J. M., and Sholkovitz, E. R.: Mechanism of iron removal in estuaries, Geochim. Cosmochim. Acta, 41, 1313-1324, https://doi.org/10.1016/0016-7037(77)90075-8, 1977.

Brown, G. H., Sharp, M. J., Tranter, M., Gurnell, A. M., and Nienow, P. W.: Impact of post-mixing chemical reactions on the major ion chemistry of bulk meltwaters draining the haut glacier d'arolla, valais, Switzerland, Hydrol. Process., 8, 465480, https://doi.org/10.1002/hyp.3360080509, 1994.

Brown, M. T., Lippiatt, S. M., and Bruland, K. W.: Dissolved aluminum, particulate aluminum, and silicic acid in northern Gulf of Alaska coastal waters: Glacial/riverine inputs and extreme reactivity, Mar. Chem., 122, 160-175, https://doi.org/10.1016/j.marchem.2010.04.002, 2010.

Browning, T. J., Achterberg, E. P., Rapp, I., Engel, A., Bertrand, E. M., Tagliabue, A., and Moore, C. M.: Nutrient co-limitation at the boundary of an oceanic gyre, Nature, 551, 242-246, https://doi.org/10.1038/nature24063, 2017.

Bucciarelli, E., Blain, S., and Treguer, P.: Iron and manganese in the wake of the Kerguelen Islands (Southern Ocean), Mar. Chem., 73, 21-36, 2001.

Bullard, J. E.: Contemporary glacigenic inputs to the dust cycle, Earth Surf. Process. Landf., 38, 71-89, https://doi.org/10.1002/esp.3315, 2013.

Cable, S., Christiansen, H. H., Westergaard-Nielsen, A., Kroon, A., and Elberling, B.: Geomorphological and cryostratigraphical analyses of the Zackenberg Valley, NE Greenland and significance of Holocene alluvial fans, Geomorphology, 303, 504-523, https://doi.org/10.1016/j.geomorph.2017.11.003, 2018.

Calleja, M. L., Kerhervé, P., Bourgeois, S., Kędra, M., Leynaert, A., Devred, E., Babin, M., and Morata, N.: Effects of increase glacier discharge on phytoplankton bloom dynamics and pelagic geochemistry in a high Arctic fjord, Prog. Oceanogr., 159, 195210, https://doi.org/10.1016/j.pocean.2017.07.005, 2017.

Cantoni, C., Hopwood, M., Clarke, J., Chiggiato, J., Achterberg, E. P., and Cozzi, S.: Hydrological, biogeochemical and carbonate system data in coastal waters and in glacier drainage systems in Kongsfjorden (Svalbard), during July-August 2016, Data set, PANGAEA, https://doi.org/10.1594/PANGAEA.904171, 2019.

Cape, M. R., Straneo, F., Beaird, N., Bundy, R. M., and Charette, M. A.: Nutrient release to oceans from buoyancy-driven upwelling at Greenland tidewater glaciers, Nat. Geosci., 12, 34-39, https://doi.org/10.1038/s41561-018-0268-4, 2019.

Carlson, D. F. and Rysgaard, S.: Adapting open-source drone autopilots for real-time iceberg observations, MethodsX, 5, 10591072, https://doi.org/10.1016/j.mex.2018.09.003, 2018.

Carlson, D. F., Boone, W., Meire, L., Abermann, J., and Rysgaard, S.: Bergy Bit and Melt Water Trajectories in Godthåbsfjord (SW Greenland) Observed by the Expendable Ice Tracker, Front. Mar. Sci., 4, 276, https://doi.org/10.3389/fmars.2017.00276, 2017.

Carroll, D., Sutherland, D. A., Shroyer, E. L., Nash, J. D., Catania, G. A., and Stearns, L. A.: Modeling Turbulent Subglacial Meltwater Plumes: Implications for Fjord-Scale 
Buoyancy-Driven Circulation, J. Phys. Oceanogr., 45, 21692185, https://doi.org/10.1175/JPO-D-15-0033.1, 2015.

Carroll, D., Sutherland, D. A., Hudson, B., Moon, T., Catania, G. A., Shroyer, E. L., Nash, J. D., Bartholomaus, T. C., Felikson, D., Stearns, L. A., Noël, B. P. Y., and van den Broeke, M. R.: The impact of glacier geometry on meltwater plume structure and submarine melt in Greenland fjords, Geophys. Res. Lett., 43, 9739-9748, https://doi.org/10.1002/2016GL070170, 2016.

Carroll, D., Sutherland, D. A., Shroyer, E. L., Nash, J. D., Catania, G. A., and Stearns, L. A.: Subglacial discharge-driven renewal of tidewater glacier fjords, J. Geophys. Res.-Ocean., 122, 66116629, https://doi.org/10.1002/2017JC012962, 2017.

Carroll, D., Sutherland, D. A., Curry, B., Nash, J. D., Shroyer, E. L., Catania, G. A., Stearns, L. A., Grist, J. P., Lee, C. M., and de Steur, L.: Subannual and Seasonal Variability of Atlantic-Origin Waters in Two Adjacent West Greenland Fjords, J. Geophys. Res.-Ocean., 123, 6670-6687, https://doi.org/10.1029/2018JC014278, 2018.

Cauvy-Fraunié, S. and Dangles, O.: A global synthesis of biodiversity responses to glacier retreat, Nat. Ecol. Evol., 3, 1675-1685, https://doi.org/10.1038/s41559-019-1042-8, 2019.

Cauwet, G. and Sidorov, I.: The biogeochemistry of Lena River: organic carbon and nutrients distribution, Mar. Chem., 53, $211-$ 227, https://doi.org/10.1016/0304-4203(95)00090-9, 1996.

Charette, M. A. and Sholkovitz, E. R.: Oxidative precipitation of groundwater-derived ferrous iron in the subterranean estuary of a coastal bay, Geophys. Res. Lett., 29, 85, https://doi.org/10.1029/2001GL014512, 2002.

Charette, M. A., Lam, P. J., Lohan, M. C., Kwon, E. Y., Hatje, V., Jeandel, C., Shiller, A. M., Cutter, G. A., Thomas, A., Boyd, P. W., Homoky, W. B., Milne, A., Thomas, H., Andersson, P. S., Porcelli, D., Tanaka, T., Geibert, W., Dehairs, F., and Garcia-Orellana, J.: Coastal ocean and shelf-sea biogeochemical cycling of trace elements and isotopes: lessons learned from GEOTRACES, Philos. Trans. R. Soc. A, 374, 20160076, https://doi.org/10.1098/rsta.2016.0076, 2016.

Chierici, M. and Fransson, A.: Calcium carbonate saturation in the surface water of the Arctic Ocean: undersaturation in freshwater influenced shelves, Biogeosciences, 6, 2421-2431, https://doi.org/10.5194/bg-6-2421-2009, 2009.

Chu, V. W., Smith, L. C., Rennermalm, A. K., Forster, R. R., Box, J. E., and Reeh, N.: Sediment plume response to surface melting and supraglacial lake drainages on the Greenland ice sheet, J. Glaciol., 55, 1072-1082, https://doi.org/10.3189/002214309790794904, 2009.

Chu, V. W., Smith, L. C., Rennermalm, A. K., Forster, R. R., and Box, J. E.: Hydrologic controls on coastal suspended sediment plumes around the Greenland Ice Sheet, The Cryosphere, 6, 119, https://doi.org/10.5194/tc-6-1-2012, 2012.

Comeau, S., Gorsky, G., Jeffree, R., Teyssié, J.-L., and Gattuso, J.-P.: Impact of ocean acidification on a key Arctic pelagic mollusc (Limacina helicina), Biogeosciences, 6, 1877-1882, https://doi.org/10.5194/bg-6-1877-2009, 2009

Comeau, S., Jeffree, R., Teyssié, J.-L., and Gattuso, J.-P.: Response of the Arctic Pteropod Limacina helicina to Projected Future Environmental Conditions, PLoS One, 5, e11362, https://doi.org/10.1371/journal.pone.0011362, 2010.

Cook, J., Oreskes, N., Doran, P. T., Anderegg, W. R. L., Verheggen, B., Maibach, E. W., Carlton, J. S., Lewandowsky, S.,
Skuce, A. G., and Green, S. A.: Consensus on consensus: a synthesis of consensus estimates on human-caused global warming, Environ. Res. Lett., 11, 48002, https://doi.org/10.1088/17489326/11/4/048002, 2016.

Cooper, L. W., McClelland, J. W., Holmes, R. M., Raymond, P. A., Gibson, J. J., Guay, C. K., and Peterson, B. J.: Flowweighted values of runoff tracers $\left(\delta^{18} \mathrm{O}, \mathrm{DOC}, \mathrm{Ba}\right.$, alkalinity) from the six largest Arctic rivers, Geophys. Res. Lett., 35, L18606, https://doi.org/10.1029/2008GL035007, 2008.

Coupel, P., Ruiz-Pino, D., Sicre, M. A., Chen, J. F., Lee, S. H., Schiffrine, N., Li, H. L., and Gascard, J. C.: The impact of freshening on phytoplankton production in the Pacific Arctic Ocean, Prog. Oceanogr., 131, 113-125, https://doi.org/10.1016/j.pocean.2014.12.003, 2015.

Cowton, T., Slater, D., Sole, A., Goldberg, D., and Nienow, P.: Modeling the impact of glacial runoff on fjord circulation and submarine melt rate using a new subgrid-scale parameterization for glacial plumes, J. Geophys. Res.-Ocean., 120, 796-812, https://doi.org/10.1002/2014JC010324, 2015.

Crusius, J., Schroth, A. W., Gasso, S., Moy, C. M., Levy, R. C., and Gatica, M.: Glacial flour dust storms in the Gulf of Alaska: Hydrologic and meteorological controls and their importance as a source of bioavailable iron, Geophys. Res. Lett., 38, 06602, https://doi.org/10.1029/2010gl046573, 2011.

Crusius, J., Schroth, A. W., Resing, J. A., Cullen, J., and Campbell, R. W.: Seasonal and spatial variabilities in northern Gulf of Alaska surface water iron concentrations driven by shelf sediment resuspension, glacial meltwater, a Yakutat eddy, and dust, Global Biogeochem. Cy., 31, 942-960, https://doi.org/10.1002/2016GB005493, 2017.

Csank, A. Z., Czimczik, C. I., Xu, X., and Welker, J. M.: Seasonal patterns of riverine carbon sources and export in NW Greenland, J. Geophys. Res.-Biogeosci., 124, 840-856, https://doi.org/10.1029/2018JG004895, 2019.

Cushman-Roisin, B., Asplin, L., and Svendsen, H.: Upwelling in broad fjords, Cont. Shelf Res., 14, 1701-1721, https://doi.org/10.1016/0278-4343(94)90044-2, 1994.

De Andrés, E., Slater, D. A., Straneo, F., Otero, J., Das, S., and Navarro, F.: Surface emergence of glacial plumes determined by fjord stratification, The Cryosphere Discuss., https://doi.org/10.5194/tc-2019-264, in review, 2020.

Debaar, H. J. W.: VonLiebig Law of the minimum and plankton ecology (1899-1991), Prog. Oceanogr., 33, 347-386, https://doi.org/10.1016/0079-6611(94)90022-1, 1994.

Dickson, A. G. and Millero, F. J.: A comparison of the equilibrium constants for the dissociation of carbonic acid in seawater media, Deep Sea Res. Part A, 34, 1733-1743, https://doi.org/10.1016/0198-0149(87)90021-5, 1987.

Dittmar, T. and Kattner, G.: The biogeochemistry of the river and shelf ecosystem of the Arctic Ocean: a review, Mar. Chem., 83, 103-120, https://doi.org/10.1016/S0304-4203(03)00105-1, 2003.

Doney, S. C., Fabry, V. J., Feely, R. A., and Kleypas, J. A.: Ocean Acidification: The Other $\mathrm{CO}_{2}$ Problem, Ann. Rev. Mar. Sci., 1, 169-192, https://doi.org/10.1146/annurev.marine.010908.163834, 2009.

Ducklow, H. W., Vernet, M., and Prezelin, B.: Dissolved inorganic nutrients including 5 macro nutrients: silicate, phosphate, nitrate, nitrite, and ammonium from water column bottle sam- 
ples collected during annual cruise along western Antarctic Peninsula, 1991-2019, ver 8, Environmental Data Initiative, https://doi.org/10.6073/pasta/9611089f65d3cbd0801204d174eee947, 2017.

Dugdale, R. C., Wilkerson, F. P., and Minas, H. J.: The role of a silicate pump in driving new production, Deep. Res. I, 42, 697719, 1995.

Egge, J. K. and Aksnes, D. L.: Silicate as regulating nutrient in phytoplankton competition, Mar. Ecol. Prog. Ser., 83, 281-289, 1992.

Egge, J. K. and Heimdal, B. R.: Blooms of phytoplankton including Emiliania huxleyi (Haptophyta). Effects of nutrient supply in different N: $\mathrm{P}$ ratios, Sarsia, 79, 333-348, https://doi.org/10.1080/00364827.1994.10413565, 1994.

Ellegaard, M. and Ribeiro, S.: The long-term persistence of phytoplankton resting stages in aquatic 'seed banks,' Biol. Rev., 93, 166-183, https://doi.org/10.1111/brv.12338, 2018.

Emmerton, C. A., Lesack, L. F. W., and Vincent, W. F.: Nutrient and organic matter patterns across the Mackenzie River, estuary and shelf during the seasonal recession of sea-ice, J. Mar. Syst., 74, 741-755, https://doi.org/10.1016/j.jmarsys.2007.10.001, 2008.

Enderlin, E. M., Howat, I. M., Jeong, S., Noh, M.-J., van Angelen, J. H., and van den Broeke, M. R.: An improved mass budget for the Greenland ice sheet, Geophys. Res. Lett., 41, 866-872, https://doi.org/10.1002/2013GL059010, 2014.

Enderlin, E. M., Carrigan, C. J., Kochtitzky, W. H., Cuadros, A., Moon, T., and Hamilton, G. S.: Greenland iceberg melt variability from high-resolution satellite observations, The Cryosphere, 12, 565-575, https://doi.org/10.5194/tc-12-565-2018, 2018.

Ericson, Y., Falck, E., Chierici, M., Fransson, A., and Kristiansen, S.: Marine $\mathrm{CO}_{2}$ system variability in a high arctic tidewaterglacier fjord system, Tempelfjorden, Svalbard, Cont. Shelf Res., 181, 1-13, https://doi.org/10.1016/j.csr.2019.04.013, 2019.

Etherington, L. L. and Hooge, P. N.: Oceanography of Glacier Bay, Alaska: Implications for biological patterns in a glacial fjord estuary, Estuar. Coast., 30, 927-944, 2007.

Evans, W., Mathis, J. T., and Cross, J. N.: Calcium carbonate corrosivity in an Alaskan inland sea, Biogeosciences, 11, 365-379, https://doi.org/10.5194/bg-11-365-2014, 2014.

Fransson, A. and Chierici, M.: Marine $\mathrm{CO}_{2}$ system data for the Svalbard fjord Kongsfjorden and the West-Spitsbergen shelf in July 2012-2014, Data set]. Norwegian Polar Institute, https://doi.org/10.21334/npolar.2019.e53eae53, 2019.

Fransson, A., Chierici, M., Nomura, D., Granskog, M. A., Kristiansen, S., Martma, T., and Nehrke, G.: Effect of glacial drainage water on the $\mathrm{CO}_{2}$ system and ocean acidification state in an Arctic tidewater-glacier fjord during two contrasting years, J. Geophys. Res.-Ocean., 120, 2413-2429, https://doi.org/10.1002/2014JC010320, 2015.

Fransson, A., Chierici, M., Hop, H., Findlay, H. S., Kristiansen, S., and Wold, A.: Late winter-to-summer change in ocean acidification state in Kongsfjorden, with implications for calcifying organisms, Polar Biol., 39, 1841-1857, https://doi.org/10.1007/s00300-016-1955-5, 2016.

Fried, M. J., Catania, G. A., Stearns, L. A., Sutherland, D. A., Bartholomaus, T. C., Shroyer, E., and Nash, J.: Reconciling drivers of seasonal terminus advance and retreat at 13 central west Greenland tidewater glaciers, J. Geophys. Res.-Earth, 123, 1590-1607, 2018.
Fuentes, V., Alurralde, G., Meyer, B., Aguirre, G. E., Canepa, A., Wölfl, A.-C., Hass, C. H., Williams, G. N., and Schloss, I. R.: Glacial melting: an overlooked threat to Antarctic krill, Sci. Rep., 6, 27234, https://doi.org/10.1038/srep27234, 2016.

Gerringa, L. J. A., Alderkamp, A.-C., Laan, P., Thuroczy, C.E., De Baar, H. J. W., Mills, M. M., van Dijken, G. L., van Haren, H., and Arrigo, K. R.: Iron from melting glaciers fuels the phytoplankton blooms in Amundsen Sea (Southern Ocean): Iron biogeochemistry, Deep. Res. Part Ii, 71-76, 16-31, https://doi.org/10.1016/j.dsr2.2012.03.007, 2012.

Gilbert, G. L., O'Neill, H. B., Nemec, W., Thiel, C., Christiansen, H. H., and Buylaert, J.-P.: Late Quaternary sedimentation and permafrost development in a Svalbard fjordvalley, Norwegian high Arctic, Sedimentology, 65, 2531-2558, https://doi.org/10.1111/sed.12476, 2018.

Gladish, C. V, Holland, D. M., Rosing-Asvid, A., Behrens, J. W., and Boje, J.: Oceanic Boundary Conditions for Jakobshavn Glacier. Part I: Variability and Renewal of Ilulissat Icefjord Waters, 2001-14, J. Phys. Oceanogr., 45, 3-32, https://doi.org/10.1175/JPO-D-14-0044.1, 2014.

Gledhill, M. and Buck, K. N.: The organic complexation of iron in the marine environment: a review, Front. Microbiol., 3, 69, https://doi.org/10.3389/fmicb.2012.00069, 2012.

Glud, R. N., Risgaard-Petersen, M., Thamdrup, B., Fossing, H., and Rysgaard, S.: Benthic carbon mineralization in a high-Arctic sound (Young Sound, NE Greenland), Mar. Ecol. Prog. Ser., 206, 59-71, https://doi.org/10.3354/meps206059, 2000.

González-Bergonzoni, I., L., J. K., Anders, M., Frank, L., Erik, J., and A., D. T.: Small birds, big effects: the little auk (Alle alle) transforms high Arctic ecosystems, P. Roy. Soc. B, 284, 20162572, https://doi.org/10.1098/rspb.2016.2572, 2017.

Grand, M. M., Clinton-Bailey, G. S., Beaton, A. D., Schaap, A. M., Johengen, T. H., Tamburri, M. N., Connelly, D. P., Mowlem, M. C., and Achterberg, E. P.: A Lab-On-Chip Phosphate Analyzer for Long-term In Situ Monitoring at Fixed Observatories: Optimization and Performance Evaluation in Estuarine and Oligotrophic Coastal Waters, Front. Mar. Sci., 4, 255, https://doi.org/10.3389/fmars.2017.00255, 2017.

Grand, M. M., Laes-Huon, A., Fietz, S., Resing, J. A., Obata, H., Luther, G. W., Tagliabue, A., Achterberg, E. P., Middag, R., Tovar-Sánchez, A., and Bowie, A. R.: Developing Autonomous Observing Systems for Micronutrient Trace Metals, Front. Mar. Sci., 6, 35, https://doi.org/10.3389/fmars.2019.00035, 2019.

Halbach, L., Vihtakari, M., Duarte, P., Everett, A., Granskog, M. A., Hop, H., Kauko, H. M., Kristiansen, S., Myhre, P. I., Pavlov, A. K., Pramanik, A., Tatarek, A., Torsvik, T., Wiktor, J. M., Wold, A., Wulff, A., Steen, H., and Assmy, P.: Tidewater Glaciers and Bedrock Characteristics Control the Phytoplankton Growth Environment in a Fjord in the Arctic, Front. Mar. Sci., 6, 254, https://doi.org/10.3389/fmars.2019.00254, 2019.

Harrison, W. G., Platt, T., and Irwin, B.: Primary Production and Nutrient Assimilation by Natural Phytoplankton Populations of the Eastern Canadian Arctic, Can. J. Fish. Aquat. Sci., 39, 335345, https://doi.org/10.1139/f82-046, 1982.

Hart, T. J.: Discovery Reports, Discov. Reports, VIII, 1-268, 1934. Hawkings, J., Wadham, J., Tranter, M., Telling, J., Bagshaw, E., Beaton, A., Simmons, S.-L., Chandler, D., Tedstone, A., and Nienow, P.: The Greenland Ice Sheet as a hot spot of phosphorus 
weathering and export in the Arctic, Global Biogeochem. Cy., 30, 191-210, https://doi.org/10.1002/2015GB005237, 2016.

Hawkings, J. R., Wadham, J. L., Tranter, M., Raiswell, R., Benning, L. G., Statham, P. J., Tedstone, A., Nienow, P., Lee, K., and Telling, J.: Ice sheets as a significant source of highly reactive nanoparticulate iron to the oceans, Nat. Commun., 5, 3929, https://doi.org/10.1038/ncomms4929, 2014.

Hawkings, J. R., Wadham, J. L., Benning, L. G., Hendry, K. R., Tranter, M., Tedstone, A., Nienow, P., and Raiswell, R.: Ice sheets as a missing source of silica to the polar oceans, Nat. Commun., 8, 14198, https://doi.org/10.1038/ncomms14198, 2017.

Hegseth, E. N. and Tverberg, V.: Effect of Atlantic water inflow on timing of the phytoplankton spring bloom in a high Arctic fjord (Kongsfjorden, Svalbard), J. Mar. Syst., 113-114, 94-105, https://doi.org/10.1016/j.jmarsys.2013.01.003, 2013.

Helly, J. J., Kaufmann, R. S., Stephenson Jr., G. R., and Vernet, M.: Cooling, dilution and mixing of ocean water by free-drifting icebergs in the Weddell Sea, Deep. Res. Part I, 58, 1346-1363, https://doi.org/10.1016/j.dsr2.2010.11.010, 2011.

Hendry, K. R., Huvenne, V. A. I., Robinson, L. F., Annett, A., Badger, M., Jacobel, A. W., Ng, H. C., Opher, J., Pickering, R. A., Taylor, M. L., Bates, S. L., Cooper, A., Cushman, G. G., Goodwin, C., Hoy, S., Rowland, G., Samperiz, A., Williams, J. A., Achterberg, E. P., Arrowsmith, C., Brearley, J. A., Henley, S. F., Krause, J. W., Leng, M. J., Li, T., McManus, J. F., Meredith, M. P., Perkins, R., and Woodward, E. M. S.: The biogeochemical impact of glacial meltwater from Southwest Greenland, Prog. Oceanogr., 176, 102126, https://doi.org/10.1016/j.pocean.2019.102126, 2019.

Henson, S., Le Moigne, F., and Giering, S.: Drivers of Carbon Export Efficiency in the Global Ocean, Global Biogeochem. Cy., 33, 891-903, https://doi.org/10.1029/2018GB006158, 2019.

Hessen, D. O., Carroll, J., Kjeldstad, B., Korosov, A. A., Pettersson, L. H., Pozdnyakov, D., and Sørensen, K.: Input of organic carbon as determinant of nutrient fluxes, light climate and productivity in the $\mathrm{Ob}$ and Yenisey estuaries, Estuar. Coast Shelf Sci., 88, 5362, https://doi.org/10.1016/j.ecss.2010.03.006, 2010.

Hewitt, I. J.: Subglacial Plumes, Annu. Rev. Fluid Mech., 52, 145-169, https://doi.org/10.1146/annurev-fluid-010719-060252, 2020.

Hodal, H., Falk-Petersen, S., Hop, H., Kristiansen, S., and Reigstad, M.: Spring bloom dynamics in Kongsfjorden, Svalbard: nutrients, phytoplankton, protozoans and primary production, Polar Biol., 35, 191-203, https://doi.org/10.1007/s00300-011-1053-7, 2012.

Hodson, A., Mumford, P., and Lister, D.: Suspended sediment and phosphorus in proglacial rivers: bioavailability and potential impacts upon the $\mathrm{P}$ status of ice-marginal receiving waters, Hydrol. Process., 18, 2409-2422, https://doi.org/10.1002/hyp.1471, 2004.

Hodson, A., Nowak, A., and Christiansen, H.: Glacial and periglacial floodplain sediments regulate hydrologic transfer of reactive iron to a high arctic fjord, Hydrol. Process., 30, 12191229, https://doi.org/10.1002/hyp.10701, 2016.

Hodson, A., Nowak, A., Sabacka, M., Jungblut, A., Navarro, F., Pearce, D., Ávila-Jiménez, M. L., Convey, P., and Vieira, G.: Climatically sensitive transfer of iron to maritime Antarctic ecosystems by surface runoff, Nat. Commun., 8, 14499, https://doi.org/10.1038/ncomms14499, 2017.
Hodson, A. J., Mumford, P. N., Kohler, J., and Wynn, P. M.: The High Arctic glacial ecosystem: New insights from nutrient budgets, Biogeochemistry, 72, 233-256, https://doi.org/10.1007/s10533-004-0362-0, 2005.

Höfer, J., Giesecke, R., Hopwood, M. J., Carrera, V., Alarcón, E., and González, H. E.: The role of water column stability and wind mixing in the production/export dynamics of two bays in the Western Antarctic Peninsula, Prog. Oceanogr., 174, 105-116, https://doi.org/10.1016/j.pocean.2019.01.005, 2019.

Holding, J. M., Duarte, C. M., Delgado-Huertas, A., Soetaert, K., Vonk, J. E., Agustí, S., Wassmann, P., and Middelburg, J. J.: Autochthonous and allochthonous contributions of organic carbon to microbial food webs in Svalbard fjords, Limnol. Oceanogr., 62, 1307-1323, https://doi.org/10.1002/lno.10526, 2017.

Holding, J. M., Markager, S., Juul-Pedersen, T., Paulsen, M. L., Møller, E. F., Meire, L., and Sejr, M. K.: Seasonal and spatial patterns of primary production in a high-latitude fjord affected by Greenland Ice Sheet run-off, Biogeosciences, 16, 3777-3792, https://doi.org/10.5194/bg-16-3777-2019, 2019.

Holmes, R. M., McClelland, J. W., Peterson, B. J., Tank, S. E., Bulygina, E., Eglinton, T. I., Gordeev, V. V., Gurtovaya, T. Y., Raymond, P. A., Repeta, D. J., Staples, R., Striegl, R. G., Zhulidov, A. V., and Zimov, S. A.: Seasonal and Annual Fluxes of Nutrients and Organic Matter from Large Rivers to the Arctic Ocean and Surrounding Seas, Estuar. Coast., 35, 369-382, https://doi.org/10.1007/s12237-011-9386-6, 2011.

Honjo, S. and Manganini, S. J.: Annual biogenic particle fluxes to the interior of the North Atlantic Ocean; studied at $34^{\circ} \mathrm{N}$ $21^{\circ} \mathrm{W}$ and $48^{\circ} \mathrm{N} 21^{\circ} \mathrm{W}$, Deep Sea Res. Part II, 40, 587-607, https://doi.org/10.1016/0967-0645(93)90034-K, 1993.

Hood, E. and Berner, L.: Effects of changing glacial coverage on the physical and biogeochemical properties of coastal streams in southeastern Alaska, J. Geophys. Res., 114, G03001, https://doi.org/10.1029/2009jg000971, 2009.

Hood, E. and Scott, D.: Riverine organic matter and nutrients in southeast Alaska affected by glacial coverage, Nat. Geosci., 1, 583-587, https://doi.org/10.1038/ngeo280, 2008.

Hood, E., Fellman, J., Spencer, R. G. M., Hernes, P. J., Edwards, R., D'Amore, D., and Scott, D.: Glaciers as a source of ancient and labile organic matter to the marine environment, Nature, 462, 1044-1047, https://doi.org/10.1038/nature08580, 2009.

Hood, E., Battin, T. J., Fellman, J., O'neel, S., and Spencer, R. G. M.: Storage and release of organic carbon from glaciers and ice sheets, Nat. Geosci., 8, 91-96, https://doi.org/10.1038/ngeo2331, 2015.

Hop, H., Pearson, T., Hegseth, E. N., Kovacs, K. M., Wiencke, C., Kwasniewski, S., Eiane, K., Mehlum, F., Gulliksen, B., Wlodarska-Kowalczuk, M., Lydersen, C., Weslawski, J. M., Cochrane, S., Gabrielsen, G. W., Leakey, R. J. G., Lønne, O. J., Zajaczkowski, M., Falk-Petersen, S., Kendall, M., Wängberg, S.-Å., Bischof, K., Voronkov, A. Y., Kovaltchouk, N. A., Wiktor, J., Poltermann, M., Prisco, G., Papucci, C., and Gerland, S.: The marine ecosystem of Kongsfjorden, Svalbard, Polar Res., 21, 167-208, 2002.

Hop, H., Assmy, P., Wold, A., Sundfjord, A., Daase, M., Duarte, P., Kwasniewski, S., Gluchowska, M., Wiktor, J. M., Tatarek, A., Wiktor, J., Kristiansen, S., Fransson, A., Chierici, M., and Vihtakari, M.: Pelagic Ecosystem Characteristics Across the Atlantic Water Boundary Current From Rijpfjorden, Svalbard, to the Arc- 
tic Ocean During Summer (2010-2014), Front. Mar. Sci., 6, 181, https://doi.org/10.3389/fmars.2019.00181, 2019.

Hoppe, H.-G.: Phosphatase activity in the sea, Hydrobiologia, 493, 187-200, https://doi.org/10.1023/A:1025453918247, 2003.

Hopwood, M. J., Connelly, D. P., Arendt, K. E., JuulPedersen, T., Stinchcombe, M. C., Meire, L., Esposito, M., and Krishna, R.: Seasonal changes in $\mathrm{Fe}$ along a glaciated Greenlandic fjord, Front. Earth Sci., 4, 15, https://doi.org/10.3389/feart.2016.00015, 2016.

Hopwood, M. J., Cantoni, C., Clarke, J. S., Cozzi, S., and Achterberg, E. P.: The heterogeneous nature of $\mathrm{Fe}$ delivery from melting icebergs, Geochem. Perspect. Lett., 3, 200-209, https://doi.org/10.7185/geochemlet.1723, 2017.

Hopwood, M. J., Carroll, D., Browning, T. J., Meire, L., Mortensen, J., Krisch, S., and Achterberg, E. P.: Non-linear response of summertime marine productivity to increased meltwater discharge around Greenland, Nat. Commun., 9, 3256, https://doi.org/10.1038/s41467-018-05488-8, 2018.

Howe, J. A., Austin, W. E. N., Forwick, M., Paetzel, M., Harland, R., and Cage, A. G.: Fjord systems and archives: a review, Geol. Soc. London, Spec. Publ., 344, 5-15, https://doi.org/10.1144/SP344.2, 2010.

Hudson, B., Overeem, I., McGrath, D., Syvitski, J. P. M., Mikkelsen, A., and Hasholt, B.: MODIS observed increase in duration and spatial extent of sediment plumes in Greenland fjords, The Cryosphere, 8, 1161-1176, https://doi.org/10.5194/tc-81161-2014, 2014.

Huss, M. and Hock, R.: Global-scale hydrological response to future glacier mass loss, Nat. Clim. Change, 8, 135-140, https://doi.org/10.1038/s41558-017-0049-x, 2018.

Hyacinthe, C. and Van Cappellen, P.: An authigenic iron phosphate phase in estuarine sediments: composition, formation and chemical reactivity, Mar. Chem., 91, 227-251, 2004.

Iriarte, J. L., Pantoja, S., and Daneri, G.: Oceanographic Processes in Chilean Fjords of Patagonia: From small to large-scale studies, Prog. Oceanogr., 129, 1-7, https://doi.org/10.1016/j.pocean.2014.10.004, 2014.

Iversen, K. R. and Seuthe, L.: Seasonal microbial processes in a high-latitude fjord (Kongsfjorden, Svalbard): I. Heterotrophic bacteria, picoplankton and nanoflagellates, Polar Biol., 34, 731749, https://doi.org/10.1007/s00300-010-0929-2, 2011.

Iversen, M. H. and Robert, M. L.: Ballasting effects of smectite on aggregate formation and export from a natural plankton community, Mar. Chem., 175, 18-27, https://doi.org/10.1016/j.marchem.2015.04.009, 2015.

Jackson, R. H., Straneo, F., and Sutherland, D. A.: Externally forced fluctuations in ocean temperature at Greenland glaciers in non-summer months, Nat. Geosci., 7, 503-508, https://doi.org/10.1038/ngeo2186, 2014.

Jackson, R. H., Shroyer, E. L., Nash, J. D., Sutherland, D. A., Carroll, D., Fried, M. J., Catania, G. A., Bartholomaus, T. C., and Stearns, L. A.: Near-glacier surveying of a subglacial discharge plume: Implications for plume parameterizations, Geophys. Res. Lett., 44, 6886-6894, https://doi.org/10.1002/2017GL073602, 2017.

Jackson, R. H., Lentz, S. J., and Straneo, F.: The Dynamics of Shelf Forcing in Greenlandic Fjords, J. Phys. Oceanogr., 48, 27992827, https://doi.org/10.1175/JPO-D-18-0057.1, 2018.
Jenkins, A.: Convection-Driven Melting near the Grounding Lines of Ice Shelves and Tidewater Glaciers, J. Phys. Oceanogr., 41, 2279-2294, https://doi.org/10.1175/JPO-D-11-03.1, 2011.

Jensen, H. M., Pedersen, L., Burmeister, A., and Winding Hansen, B.: Pelagic primary production during summer along 65 to $72^{\circ} \mathrm{N}$ off West Greenland, Polar Biol., 21, 269-278, https://doi.org/10.1007/s003000050362, 1999.

Johnson, H. L., Münchow, A., Falkner, K. K., and Melling, H.: Ocean circulation and properties in Petermann Fjord, Greenland, J. Geophys. Res.-Ocean., 116, C01003, https://doi.org/10.1029/2010JC006519, 2011.

Joli, N., Gosselin, M., Ardyna, M., Babin, M., Onda D. F., Tremblay, J.-É., and Lovejoy, C.: Need for focus on microbial species following ice melt and changing freshwater regimes in a Janus Arctic Gateway, Sci. Rep., 8, 9405, https://doi.org/10.1038/s41598-018-27705-6, 2018.

Jones, I. W., Munhoven, G., Tranter, M., Huybrechts, P., and Sharp, M. J.: Modelled glacial and non-glacial $\mathrm{HCO}_{3}^{-}$, Si and Ge fluxes since the LGM: little potential for impact on atmospheric $\mathrm{CO}_{2}$ concentrations and a potential proxy of continental chemical erosion, the marine Ge/Si ratio, Global Planet. Chang., 33, 139153, https://doi.org/10.1016/S0921-8181(02)00067-X, 2002.

Jouvet, G., Weidmann, Y., Kneib, M., Detert, M., Seguinot, J., Sakakibara, D.. and Sugiyama, S.: Short-lived ice speed-up and plume water flow captured by a VTOL UAV give insights into subglacial hydrological system of Bowdoin Glacier, Remote Sens. Environ., 217, 389-399, https://doi.org/10.1016/j.rse.2018.08.027, 2018.

Juul-Pedersen, T., Arendt, K. E., Mortensen, J., Blicher, M. E., Søgaard, D., and Rysgaard, S.: Seasonal and interannual phytoplankton production in a sub-Arctic tidewater outlet glacier fjord, SW Greenland, Mar. Ecol. Prog. Ser., 524, 27-38, https://doi.org/10.3354/meps11174, 2015.

Kanna, N., Sugiyama, S., Ohashi, Y., Sakakibara, D., Fukamachi, Y., and Nomura, D.: Upwelling of macronutrients and dissolved inorganic carbon by a subglacial freshwater driven plume in Bowdoin Fjord, northwestern Greenland, J. Geophys. Res.-Biogeosci., 123, 1666-1682, https://doi.org/10.1029/2017JG004248, 2018.

Kjeldsen, K. K., Mortensen, J., Bendtsen, J., Petersen, D., Lennert, K., and Rysgaard, S.: Ice-dammed lake drainage cools and raises surface salinities in a tidewater outlet glacier fjord, west Greenland, J. Geophys. Res.-Surf., 119, 1310-1321, https://doi.org/10.1002/2013JF003034, 2014.

Klunder, M. B., Bauch, D., Laan, P., de Baar, H. J. W., van Heuven, S., and Ober, S.: Dissolved iron in the Arctic shelf seas and surface waters of the central Arctic Ocean: Impact of Arctic river water and ice-melt, J. Geophys. Res., 117, C01027, https://doi.org/10.1029/2011jc007133, 2012.

Knutz, P. C., Sicre, M.-A., Ebbesen, H., Christiansen, S., and Kuijpers, A.: Multiple-stage deglacial retreat of the southern Greenland Ice Sheet linked with Irminger Current warm water transport, Paleoceanography, 26, PA3204, https://doi.org/10.1029/2010PA002053, 2011.

Kohfeld, K. E. and Harrison, S. P.: DIRTMAP: the geological record of dust, Earth-Science Rev., 54, 81-114, https://doi.org/10.1016/S0012-8252(01)00042-3, 2001.

Koziorowska, K., Kuliński, K., and Pempkowiak, J.: Deposition, return flux, and burial rates of nitrogen and phosphorus in the 
sediments of two high-Arctic fjords, Oceanologia, 60, 431-445, https://doi.org/10.1016/j.oceano.2018.05.001, 2018.

Krawczyk, D. W., Witkowski, A., Juul-Pedersen, T., Arendt, K. E., Mortensen, J., and Rysgaard, S.: Microplankton succession in a SW Greenland tidewater glacial fjord influenced by coastal inflows and run-off from the Greenland Ice Sheet, Polar Biol., 38, 1515-1533, https://doi.org/10.1007/s00300-015-1715-y, 2015.

Krawczyk, D. W., Meire, L., Lopes, C., Juul-Pedersen, T., Mortensen, J., Li, C. L., and Krogh, T.: Seasonal succession, distribution, and diversity of planktonic protists in relation to hydrography of the Godthåbsfjord system (SW Greenland), Polar Biol., 41, 2033-2052, https://doi.org/10.1007/s00300-018-23430, 2018.

Kumar, V., Tiwari, M., and Rengarajan, R.: Warming in the Arctic Captured by productivity variability at an Arctic Fjord over the past two centuries, PLoS One, 13, e0201456, https://doi.org/10.1371/journal.pone.0201456, 2018.

Kwiatkowski, L., Naar, J., Bopp, L., Aumont, O., Defrance, D., and Couespel, D.: Decline in Atlantic primary production accelerated by Greenland ice sheet melt, Geophys. Res. Lett., 46, 1134711357, https://doi.org/10.1029/2019GL085267, 2019.

Laidre, K. L., Twila, M., Hauser, D. D. W., McGovern, R., HeideJørgensen, M. P., Rune, D., and Hudson, B.: Use of glacial fronts by narwhals (Monodon monoceros) in West Greenland, Biol. Lett., 12, 20160457, https://doi.org/10.1098/rsbl.2016.0457, 2016.

Lam, P. J. and Bishop, J. K. B.: The continental margin is a key source of iron to the HNLC North Pacific Ocean, Geophys. Res. Lett., 35, L07608, https://doi.org/10.1029/2008g1033294, 2008.

Langen, P. L., Mottram, R. H., Christensen, J. H., Boberg, F., Rodehacke, C. B., Stendel, M., van As, D., Ahlstrøm, A. P., Mortensen, J., Rysgaard, S., Petersen, D., Svendsen, K. H., Aðalgeirsdóttir, G., and Cappelen, J.: Quantifying energy and mass fluxes controlling Godthåbsfjord freshwater input in a 5-km simulation (1991-2012), J. Climate, 28, 3694-3713, https://doi.org/10.1175/JCLI-D-14-00271.1, 2015.

Larsen, A., Egge, J. K., Nejstgaard, J. C., Di Capua, I., Thyrhaug, R., Bratbak, G., and Thingstad, T. F.: Contrasting response to nutrient manipulation in Arctic mesocosms are reproduced by a minimum microbial food web model, Limnol. Oceanogr., 60, 360-374, https://doi.org/10.1002/lno.10025, 2015.

Lawson, E. C., Bhatia, M. P., Wadham, J. L., and Kujawinski, E. B.: Continuous Summer Export of Nitrogen-Rich Organic Matter from the Greenland Ice Sheet Inferred by Ultrahigh Resolution Mass Spectrometry, Environ. Sci. Technol., 48, 14248-14257, https://doi.org/10.1021/es501732h, 2014a.

Lawson, E. C., Wadham, J. L., Tranter, M., Stibal, M., Lis, G. P., Butler, C. E. H., Laybourn-Parry, J., Nienow, P., Chandler, D., and Dewsbury, P.: Greenland Ice Sheet exports labile organic carbon to the Arctic oceans, Biogeosciences, 11, 4015-4028, https://doi.org/10.5194/bg-11-4015-2014, 2014b.

Le Bras, I. A.-A., Straneo, F., Holte, J., and Holliday, N. P.: Seasonality of Freshwater in the East Greenland Current System From 2014 to 2016, J. Geophys. Res.-Ocean., 123, 8828-8848, https://doi.org/10.1029/2018JC014511, 2018.

Lecavalier, B. S., Fisher, D. A., Milne, G. A., Vinther, B. M., Tarasov, L., Huybrechts, P., Lacelle, D., Main, B., Zheng, J., Bourgeois, J., and Dyke, A. S.: High Arctic Holocene temperature record from the Agassiz ice cap and Greenland ice sheet evolution, P. Natl. Acad. Sci. USA, 114, 5952-5957, https://doi.org/10.1073/pnas.1616287114, 2017.

Lefebvre, K. A., Quakenbush, L., Frame, E., Huntington, K. B., Sheffield, G., Stimmelmayr, R., Bryan, A., Kendrick, P., Ziel, H., Goldstein, T., Snyder, J. A., Gelatt, T., Gulland, F., Dickerson, B., and Gill, V.: Prevalence of algal toxins in Alaskan marine mammals foraging in a changing arctic and subarctic environment, Harmful Algae, 55, 13-24, https://doi.org/10.1016/j.hal.2016.01.007, 2016.

Le Fouest, V., Babin, M., and Tremblay, J.-É.: The fate of riverine nutrients on Arctic shelves, Biogeosciences, 10, 3661-3677, https://doi.org/10.5194/bg-10-3661-2013, 2013.

Le Moigne, F. A. C., Henson, S. A., Cavan, E., Georges, C., Pabortsava, K., Achterberg, E. P., Ceballos-Romero, E., Zubkov, M., and Sanders, R. J.: What causes the inverse relationship between primary production and export efficiency in the Southern Ocean?, Geophys. Res. Lett., 43, 4457-4466, https://doi.org/10.1002/2016GL068480, 2016.

León-Muñoz, J., Urbina, M. A., Garreaud, R., and Iriarte, J. L.: Hydroclimatic conditions trigger record harmful algal bloom in western Patagonia (summer 2016), Sci. Rep., 8, 1330, https://doi.org/10.1038/s41598-018-19461-4, 2018.

Levinsen, H. and Nielsen, T. G.: The trophic role of marine pelagic ciliates and heterotrophic dinoflagellates in arctic and temperate coastal ecosystems: A crosslatitude comparison, Limnol. Oceanogr., 47, 427-439, https://doi.org/10.4319/lo.2002.47.2.0427, 2002.

Liestøl, O.: The glaciers in the Kongsfjorden area, Spitsbergen, Nor. Geogr. Tidsskr. - Nor. J. Geogr., 42, 231-238, https://doi.org/10.1080/00291958808552205, 1988.

Lin, H., Rauschenberg, S., Hexel, C. R., Shaw, T. J., and Twining, B. S.: Free-drifting icebergs as sources of iron to the Weddell Sea, Deep. Res. Part Ii-Topical Stud. Oceanogr., 58, 1392-1406, https://doi.org/10.1016/j.dsr2.2010.11.020, 2011.

Lippiatt, S. M., Lohan, M. C., and Bruland, K. W.: The distribution of reactive iron in northern Gulf of Alaska coastal waters, Mar. Chem., 121, 187-199, https://doi.org/10.1016/j.marchem.2010.04.007, 2010.

Lischka, S. and Riebesell, U.: Synergistic effects of ocean acidification and warming on overwintering pteropods in the Arctic, Global Chang. Biol., 18, 3517-3528, https://doi.org/10.1111/gcb.12020, 2012.

Lischka, S., Büdenbender, J., Boxhammer, T., and Riebesell, U.: Impact of ocean acidification and elevated temperatures on early juveniles of the polar shelled pteropod Limacina helicina: mortality, shell degradation, and shell growth, Biogeosciences, 8, 919-932, https://doi.org/10.5194/bg-8-919-2011, 2011.

Lund-Hansen, L. C., Hawes, I., Holtegaard Nielsen, M., Dahllöf, I., and Sorrell, B. K.: Summer meltwater and spring sea ice primary production, light climate and nutrients in an Arctic estuary, Kangerlussuaq, west Greenland, Arctic, Antarct. Alp. Res., 50, S100025, https://doi.org/10.1080/15230430.2017.1414468, 2018.

Lydersen, C., Assmy, P., Falk-Petersen, S., Kohler, J., Kovacs, K. M., Reigstad, M., Steen, H., Strøm, H., Sundfjord, A., Varpe, Ø., Walczowski, W., Weslawski, J. M., and Zajaczkowski, M.: The importance of tidewater glaciers for marine mammals and seabirds in Svalbard, Norway, J. Mar. Syst., 129, 452-471, https://doi.org/10.1016/j.jmarsys.2013.09.006, 2014. 
Maat, D. S., Prins, M. A., and Brussaard, C. P. D.: Sediments from Arctic Tide-Water Glaciers Remove Coastal Marine Viruses and Delay Host Infection, Viruses, 11, 123, https://doi.org/10.3390/v11020123, 2019.

Mankoff, K. D., Straneo, F., Cenedese, C., Das, S. B., Richards, C. G., and Singh, H.: Structure and dynamics of a subglacial discharge plume in a Greenlandic Fjord, J. Geophys. Res.-Ocean., 121, 8670-8688, https://doi.org/10.1002/2016JC011764, 2016.

Markussen, T. N., Elberling, B., Winter, C., and Andersen, T. J.: Flocculated meltwater particles control Arctic land-sea fluxes of labile iron, Sci. Rep., 6, 24033, https://doi.org/10.1038/srep24033, 2016.

Marsay, C. M., Barrett, P. M., McGillicuddy, D. J., and Sedwick, P. N.: Distributions, sources, and transformations of dissolved and particulate iron on the Ross Sea continental shelf during summer, J. Geophys. Res.-Ocean., 122, 6371-6393, https://doi.org/10.1002/2017JC013068, 2017.

Martin, J. H.: Glacial-interglacial $\mathrm{CO}_{2}$ change?: The iron hypothesis, Paleoceanography, 5, 1-13, 1990.

Martin, J. H., Fitzwater, S. E., and Gordon, R. M.: Iron deficiency limits phytoplankton growth in Antarctic waters, Global Biogeochem. Cy., 4, 5-12, 1990a.

Martin, J. H., Gordon, R. M., and Fitzwater, S. E.: Iron in Antarctic waters, Nature, 345, 156-158, https://doi.org/10.1038/345156a0, $1990 \mathrm{~b}$.

Mascarenhas, V. J. and Zielinski, O.: Hydrography-Driven Optical Domains in the Vaigat-Disko Bay and Godthabsfjord: Effects of Glacial Meltwater Discharge, Front. Mar. Sci., 6, 335, https://doi.org/10.3389/fmars.2019.00335, 2019.

Mascioni, M., Almandoz, G. O., Cefarelli, A. O., Cusick, A., Ferrario, M. E., and Vernet, M.: Phytoplankton composition and bloom formation in unexplored nearshore waters of the western Antarctic Peninsula, Polar Biol., 42, 1859-1872, https://doi.org/10.1007/s00300-019-02564-7, 2019.

Meire, L., Søgaard, D. H., Mortensen, J., Meysman, F. J. R., Soetaert, K., Arendt, K. E., Juul-Pedersen, T., Blicher, M. E., and Rysgaard, S.: Glacial meltwater and primary production are drivers of strong $\mathrm{CO}_{2}$ uptake in fjord and coastal waters adjacent to the Greenland Ice Sheet, Biogeosciences, 12, 2347-2363, https://doi.org/10.5194/bg-12-2347-2015, 2015.

Meire, L., Meire, P., Struyf, E., Krawczyk, D. W., Arendt, K. E., Yde, J. C., Juul Pedersen, T., Hopwood, M. J., Rysgaard, S., and Meysman, F. J. R.: High export of dissolved silica from the Greenland Ice Sheet, Geophys. Res. Lett., 43, 9173-9182, https://doi.org/10.1002/2016GL070191, 2016a.

Meire, L., Mortensen, J., Rysgaard, S., Bendtsen, J., Boone, W., Meire, P., and Meysman, F. J. R.: Spring bloom dynamics in a subarctic fjord influenced by tidewater outlet glaciers (Godthåbsfjord, SW Greenland), J. Geophys. Res.-Biogeosci., 121, 15811592, https://doi.org/10.1002/2015JG003240, 2016 b.

Meire, L., Mortensen, J., Meire, P., Juul-Pedersen, T., Sejr, M. K., Rysgaard, S., Nygaard, R., Huybrechts, P., and Meysman, F. J. R.: Marine-terminating glaciers sustain high productivity in Greenland fjords, Glob. Chang. Biol., 23, 5344-5357, https://doi.org/10.1111/gcb.13801, 2017.

Milner, A. M., Khamis, K., Battin, T. J., Brittain, J. E., Barrand, N. E., Füreder, L., Cauvy-Fraunié, S., Gíslason, G. M., Jacobsen, D., Hannah, D. M., Hodson, A. J., Hood, E., Lencioni, V., Ólafsson, J. S., Robinson, C. T., Tranter, M., and Brown,
L. E.: Glacier shrinkage driving global changes in downstream systems, P. Natl. Acad. Sci. USA, 114, 9770-9778, https://doi.org/10.1073/pnas.1619807114, 2017.

Mitra, A., Flynn, K. J., Burkholder, J. M., Berge, T., Calbet, A., Raven, J. A., Granéli, E., Glibert, P. M., Hansen, P. J., Stoecker, D. K., Thingstad, F., Tillmann, U., Våge, S., Wilken, S., and Zubkov, M. V.: The role of mixotrophic protists in the biological carbon pump, Biogeosciences, 11, 995-1005, https://doi.org/10.5194/bg-11-995-2014, 2014.

Moffat, C.: Wind-driven modulation of warm water supply to a proglacial fjord, Jorge Montt Glacier, Patagonia, Geophys. Res. Lett., 41, 3943-3950, https://doi.org/10.1002/2014GL060071, 2014.

Moon, T., Sutherland, D. A., Carroll, D., Felikson, D., Kehrl, L., and Straneo, F.: Subsurface iceberg melt key to Greenland fjord freshwater budget, Nat. Geosci., 11, 49-54, https://doi.org/10.1038/s41561-017-0018-z, 2018.

Moore, C. M., Mills, M. M., Arrigo, K. R., Berman-Frank, I., Bopp, L., Boyd, P. W., Galbraith, E. D., Geider, R. J., Guieu, C., Jaccard, S. L., Jickells, T. D., La Roche, J., Lenton, T. M., Mahowald, N. M., Maranon, E., Marinov, I., Moore, J. K., Nakatsuka, T., Oschlies, A., Saito, M. A., Thingstad, T. F., Tsuda, A., and Ulloa, O.: Processes and patterns of oceanic nutrient limitation, Nat. Geosci, 6, 701-710, https://doi.org/10.1038/ngeo1765, 2013.

Morlighem, M., Williams, C. N., Rignot, E., An, L., Arndt, J. E., Bamber, J. L., Catania, G., Chauché, N., Dowdeswell, J. A., Dorschel, B., Fenty, I., Hogan, K., Howat, I., Hubbard, A., Jakobsson, M., Jordan, T. M., Kjeldsen, K. K., Millan, R., Mayer, L., Mouginot, J., Noël, B. P. Y., O'Cofaigh, C., Palmer, S., Rysgaard, S., Seroussi, H., Siegert, M. J., Slabon, P., Straneo, F., van den Broeke, M. R., Weinrebe, W., Wood, M., and Zinglersen, K. B.: BedMachine v3: Complete Bed Topography and Ocean Bathymetry Mapping of Greenland From Multibeam Echo Sounding Combined With Mass Conservation, Geophys. Res. Lett., 44, 11051-11061, https://doi.org/10.1002/2017GL074954, 2017.

Mortensen, J., Lennert, K., Bendtsen, J., and Rysgaard, S.: Heat sources for glacial melt in a sub-Arctic fjord (Godthabsfjord) in contact with the Greenland Ice Sheet, J. Geophys. Res., 116, C01013, https://doi.org/10.1029/2010jc006528, 2011.

Mortensen, J., Bendtsen, J., Lennert, K., and Rysgaard, S.: Seasonal variability of the circulation system in a west Greenland tidewater outlet glacier fjord, Godthåbsfjord $\left(64^{\circ} \mathrm{N}\right)$, J. Geophys. Res.-Earth Surf., 119, 2591-2603, https://doi.org/10.1002/2014JF003267, 2014.

Mortensen, J., Rysgaard, S., Arendt, K. E., Juul-Pedersen, T., S $\varnothing-$ gaard, D. H., Bendtsen, J., and Meire, L.: Local Coastal Water Masses Control Heat Levels in a West Greenland Tidewater Outlet Glacier Fjord, J. Geophys. Res.-Ocean., 123, 8068-8083, https://doi.org/10.1029/2018JC014549, 2018.

Morton, B. R., Taylor, G., and Turner, J. S.: Turbulent gravitational convection from maintained and instantaneous sources, Proc. R. Soc. A, 234, 1-23, https://doi.org/10.1098/rspa.1956.0011, 1956.

Mouginot, J., Rignot, E., Bjørk, A. A., van den Broeke, M., Millan, R., Morlighem, M., Noël, B., Scheuchl, B., and Wood, M.: Forty-six years of Greenland Ice Sheet mass balance from 
1972 to 2018, P. Natl. Acad. Sci. USA, 116, 9239-9244, https://doi.org/10.1073/pnas.1904242116, 2019.

Moskalik, M., Ćwiąkała, J., Szczuciński, W., Dominiczak, A., Głowacki, O., Wojtysiak, K., and Zagórski, P.: Spatiotemporal changes in the concentration and composition of suspended particulate matter in front of Hansbreen, a tidewater glacier in Svalbard, Oceanologia, 60, 446-463, https://doi.org/10.1016/j.oceano.2018.03.001, 2018.

Murray, C., Markager, S., Stedmon, C. A., Juul-Pedersen, T., Sejr, M. K., and Bruhn, A.: The influence of glacial melt water on bio-optical properties in two contrasting Greenlandic fjords, Estuar. Coast. Shelf Sci., 163, 72-83, https://doi.org/10.1016/j.ecss.2015.05.041, 2015.

Nielsdottir, M. C., Moore, C. M., Sanders, R., Hinz, D. J., and Achterberg, E. P.: Iron limitation of the postbloom phytoplankton communities in the Iceland Basin, Global Biogeochem. Cy., 23, GB3001, https://doi.org/10.1029/2008gb003410, 2009.

Nielsen, T. G.: Plankton community structure and carbon cycling on the western coast of Greenland during the stratified summer situation. I. Hydrography, phytoplankton and bacterioplankton, Aquat. Microb. Ecol., 16, 205-216, 1999.

Nielsen, T. G., and Hansen, B.: Plankton community structure and carbon cycling on the western coast of Greenland during and after the sedimentation of a diatom bloom, Mar. Ecol. Prog. Ser., 125, 239-257, 1995.

Nightingale, A. M., Beaton, A. D., and Mowlem, M. C.: Trends in microfluidic systems for in situ chemical analysis of natural waters, Sensors Actuators B Chem., 221, 1398-1405, https://doi.org/10.1016/j.snb.2015.07.091, 2015.

Noël, B., van de Berg, W. J., van Meijgaard, E., Kuipers Munneke, P., van de Wal, R. S. W., and van den Broeke, M. R.: Evaluation of the updated regional climate model RACMO2.3: summer snowfall impact on the Greenland Ice Sheet, The Cryosphere, 9, 1831-1844, https://doi.org/10.5194/tc-9-1831-2015, 2015.

Normandeau, A., Dietrich, P., Hughes Clarke, J., Van Wychen, W., Lajeunesse, P., Burgess, D., and Ghienne, J.-F.: Retreat Pattern of Glaciers Controls the Occurrence of Turbidity Currents on High-Latitude Fjord Deltas (Eastern Baffin Island), J. Geophys. Res.-Earth Surf., 124, 1559-1571, https://doi.org/10.1029/2018JF004970, 2019.

Oliver, H., Luo, H., Castelao, R. M., van Dijken, G. L., Mattingly, K., Rosen, J. J., Mote, T. L., Arrigo, K. R., Rennermalm, A. K., Tedesco, M., and Yager, P. L.: Exploring the Potential Impact of Greenland Meltwater on Stratification, Photosynthetically Active Radiation, and Primary Production in the Labrador Sea, J. Geophys. Res.-Ocean., 123, 2570-2591, https://doi.org/10.1002/2018JC013802, 2018.

Overeem, I., Hudson, B. D., Syvitski, J. P. M., Mikkelsen, A. B., Hasholt, B., Van Den Broeke, M. R., Noel, B. P. Y., and Morlighem, M.: Substantial export of suspended sediment to the global oceans from glacial erosion in Greenland, Nat. Geosci., 10, 859-863, https://doi.org/10.1038/NGEO3046, 2017.

Pabi, S., van Dijken, G. L., and Arrigo, K. R.: Primary production in the Arctic Ocean, 1998-2006, J. Geophys. Res.-Ocean., 113, C08005, https://doi.org/10.1029/2007JC004578, 2008.

Pabortsava, K., Lampitt, R. S., Benson, J., Crowe, C., McLachlan, R., Le Moigne, F. A. C., Mark Moore, C., Pebody, C., Provost, P., Rees, A. P., Tilstone, G. H., and Woodward, E. M. S.: Carbon sequestration in the deep Atlantic enhanced by Saharan dust, Nat. Geosci., 10, 189-194, https://doi.org/10.1038/ngeo2899, 2017.

Paulsen, M. L., Nielsen, S. E. B., Müller, O., Møller, E. F., Stedmon, C. A., Juul-Pedersen, T., Markager, S., Sejr, M. K., Delgado Huertas, A., Larsen, A., and Middelboe, M.: Carbon Bioavailability in a High Arctic Fjord Influenced by Glacial Meltwater, NE Greenland, Front. Mar. Sci., 4, 176, https://doi.org/10.3389/fmars.2017.00176, 2017.

Paulsen, M. L., Müller, O., Larsen, A., Møller, E. F., Middelboe, M., Sejr, M. K., and Stedmon, C.: Biological transformation of Arctic dissolved organic matter in a NE Greenland fjord, Limnol. Oceanogr., 64, 1014-1033, https://doi.org/10.1002/lno.11091, 2018.

Poorvin, L., Rinta-Kanto, J. M., Hutchins, D. A., and Wilhelm, S. W.: Viral release of iron and its bioavailability to marine plankton, Limnol. Oceanogr., 49, 1734-1741, 2004.

Prado-Fiedler, R.: Winter and summer distribution of dissolved oxygen, $\mathrm{pH}$ and nutrients at the heads of fjords in Chilean Patagonia with possible phosphorus limitation, Rev. Biol. Mar. Oceanogr., 44, 783-789, 2009.

Prospero, J. M., Bullard, J. E., and Hodgkins, R.: HighLatitude Dust Over the North Atlantic: Inputs from Icelandic Proglacial Dust Storms, Science, 80, 1078-1082, https://doi.org/10.1126/science.1217447, 2012.

Raiswell, R. and Canfield, D. E.: The Iron biogeochemical Cycle Past and Present, Geochem. Perspect., 1, 1-220, https://doi.org/10.7185/geochempersp.1.1, 2012.

Raiswell, R., Tranter, M., Benning, L. G., Siegert, M., De'ath, R., Huybrechts, P., and Payne, T.: Contributions from glacially derived sediment to the global iron (oxyhydr)oxide cycle: Implications for iron delivery to the oceans, Geochim. Cosmochim. Acta, 70, 2765-2780, https://doi.org/10.1016/j.gca.2005.12.027, 2006.

Raiswell, R., Benning, L. G., Tranter, M., and Tulaczyk, S.: Bioavailable iron in the Southern Ocean: the significance of the iceberg conveyor belt, Geochem. Trans., 9, 7, https://doi.org/10.1186/1467-4866-9-7, 2008.

Redfield, A. C.: On the proportions of organic derivations in sea water and their relation to the composition of plankton, in: James Johnstone Memorial Volume, edited by: R. J. Daniel, 177-192, University Press of Liverpool, Liverpool, 1934.

Reisdorph, S. C. and Mathis, J. T.: Assessing net community production in a glaciated Alaskan fjord, Biogeosciences, 12, 51855198, https://doi.org/10.5194/bg-12-5185-2015, 2015.

Ren, Z., Martyniuk, N., Oleksy, I. A., Swain, A., and Hotaling, S.: Ecological Stoichiometry of the Mountain Cryosphere, Front. Ecol. Evol., 7, 360, https://doi.org/10.3389/fevo.2019.00360, 2019.

Renner, M., Arimitsu, M. L., Piatt, J. F., and Rochet, M.-J.: Structure of marine predator and prey communities along environmental gradients in a glaciated fjord, Can. J. Fish. Aquat. Sci., 69, 2029-2045, https://doi.org/10.1139/f2012-117, 2012.

Ribeiro, S., Moros, M., Ellegaard, M., and Kuijpers, A.: Climate variability in West Greenland during the past 1500 years: evidence from a high-resolution marine palynological record from Disko Bay, Boreas, 41, 68-83, https://doi.org/10.1111/j.15023885.2011.00216.x, 2012.

Ribeiro, S., Sejr, M. K., Limoges, A., Heikkilä, M., Andersen, T. J., Tallberg, P., Weckström, K., Husum, K., Forwick, M., Dals- 
gaard, T., Massé, G., Seidenkrantz, M.-S., and Rysgaard, S.: Sea ice and primary production proxies in surface sediments from a High Arctic Greenland fjord: Spatial distribution and implications for palaeoenvironmental studies, Ambio, 46, 106-118, https://doi.org/10.1007/s13280-016-0894-2, 2017.

Richlen, M. L., Zielinski, O., Holinde, L., Tillmann, U., Cembella, A., Lyu, Y., and Anderson, D. M.: Distribution of Alexandrium fundyense (Dinophyceae) cysts in Greenland and Iceland, with an emphasis on viability and growth in the Arctic, Mar. Ecol. Prog. Ser., 547, 33-46, https://doi.org/10.3354/meps11660, 2016.

Rignot, E., Jacobs, S., Mouginot, J., and Scheuchl, B.: IceShelf Melting Around Antarctica, Science, 80, 266-270, https://doi.org/10.1126/science.1235798, 2013.

Rijkenberg, M. J. A., Slagter, H. A., Rutgers van der Loeff, M., van Ooijen, J., and Gerringa, L. J. A.: Dissolved $\mathrm{Fe}$ in the Deep and Upper Arctic Ocean With a Focus on Fe Limitation in the Nansen Basin, Front. Mar. Sci., 5, 88, https://doi.org/10.3389/fmars.2018.00088, 2018.

Ryan-Keogh, T. J., Macey, A. I., Nielsdottir, M. C., Lucas, M. I., Steigenberger, S. S., Stinchcombe, M. C., Achterberg, E. P., Bibby, T. S., and Moore, C. M.: Spatial and temporal development of phytoplankton iron stress in relation to bloom dynamics in the high-latitude North Atlantic Ocean, Limnol. Oceanogr., 58, 533-545, https://doi.org/10.4319/lo.2013.58.2.0533, 2013.

Rysgaard, S. and Glud, R. N.: Carbon cycling and climate change: Predictions for a high-Arctic marine ecosystem (Young Sound, NE Greenland). Meddelelser om Groenland, Bioscience, 58, 206-213, 2007.

Rysgaard, S., Nielsen, T., and Hansen, B.: Seasonal variation in nutrients, pelagic primary production and grazing in a high-Arctic coastal marine ecosystem, Young Sound, Northeast Greenland, Mar. Ecol. Prog. Ser., 179, 13-25, https://doi.org/10.3354/meps179013, 1999.

Rysgaard, S., Vang, T., Stjernholm, M., Rasmussen, B., Windelin, A., and Kiilsholm, S.: Physical conditions, carbon transport, and climate change impacts in a northeast Greenland fjord, Arct. Antarct. Alp. Res., 35, 301-312, https://doi.org/10.1657/15230430(2003)035[0301:pcctac]2.0.co;2, 2003.

Rysgaard, S., Mortensen, J., Juul-Pedersen, T., Sørensen, L. L., Lennert, K., Søgaard, D. H., Arendt, K. E., Blicher, M. E., Sejr, M. K., and Bendtsen, J.: High air-sea $\mathrm{CO}_{2}$ uptake rates in nearshore and shelf areas of Southern Greenland: Temporal and spatial variability, Mar. Chem., 128-129, 26-33, https://doi.org/10.1016/j.marchem.2011.11.002, 2012.

Ryu, J.-S. and Jacobson, A. D.: $\mathrm{CO}_{2}$ evasion from the Greenland Ice Sheet: A new carbon-climate feedback, Chem. Geol., 320-321, 80-95, https://doi.org/10.1016/j.chemgeo.2012.05.024, 2012.

Schaffer, J., Kanzow, T., von Appen, W., von Albedyll, L., Arndt, J. E., and Roberts, D. H.: Bathymetry constrains ocean heat supply to Greenland's largest glacier tongue, Nat. Geosci., 13, 227-231, https://doi.org/10.1038/s41561-019-0529-x, 2020.

Schild, K. M., Hawley, R. L., and Morriss, B. F.: Subglacial hydrology at Rink Isbræ, West Greenland inferred from sediment plume appearance, Ann. Glaciol., 57, 118-127, https://doi.org/10.1017/aog.2016.1, 2016.

Schlosser, C., Schmidt, K., Aquilina, A., Homoky, W. B., Castrillejo, M., Mills, R. A., Patey, M. D., Fielding, S., Atkinson, A., and Achterberg, E. P.: Mechanisms of dissolved and labile particulate iron supply to shelf waters and phytoplankton blooms off South Georgia, Southern Ocean, Biogeosciences, 15, 49734993, https://doi.org/10.5194/bg-15-4973-2018, 2018.

Schmidt, K., Atkinson, A., Steigenberger, S., Fielding, S., Lindsay, M. C. M., Pond, D. W., Tarling, G. A., Klevjer, T. A., Allen, C. S., Nicol, S., and Achterberg, E. P.: Seabed foraging by Antarctic krill: Implications for stock assessment, bentho-pelagic coupling, and the vertical transfer of iron, Limnol. Oceanogr., 56, 14111428, https://doi.org/10.4319/lo.2011.56.4.1411, 2011.

Schroth, A. W., Crusius, J., Chever, F., Bostick, B. C., and Rouxel, O. J.: Glacial influence on the geochemistry of riverine iron fluxes to the Gulf of Alaska and effects of deglaciation, Geophys. Res. Lett., 38, L16605, https://doi.org/10.1029/2011g1048367, 2011.

Schroth, A. W., Crusius, J., Campbell, R. W., and Hoyer, I.: Estuarine removal of glacial iron and implications for iron fluxes to the ocean, Geophys. Res. Lett., 41, 3951-3958, https://doi.org/10.1002/2014GL060199, 2014.

Sedwick, P. N., Marsay, C. M., Sohst, B. M., Aguilar-Islas, A. M., Lohan, M. C., Long, M. C., Arrigo, K. R., Dunbar, R. B., Saito, M. A., Smith, W. O., and DiTullio, G. R.: Early season depletion of dissolved iron in the Ross Sea polynya: Implications for iron dynamics on the Antarctic continental shelf, J. Geophys. Res., 116, C12019, https://doi.org/10.1029/2010JC006553, 2011.

Seifert, M., Hoppema, M., Burau, C., Elmer, C., Friedrichs, A., Geuer, J. K., John, U., Kanzow, T., Koch, B. P., Konrad, C., van der Jagt, H., Zielinski, O., and Iversen, M. H.: Influence of Glacial Meltwater on Summer Biogeochemical Cycles in Scoresby Sund, East Greenland, Front. Mar. Sci., 6, 412, https://doi.org/10.3389/fmars.2019.00412, 2019.

Sejr, M. K., Krause-Jensen, D., Rysgaard, S., Sørensen, L. L., Christensen, P. B., and Glud, R. N.: Air-sea flux of $\mathrm{CO}_{2}$ in arctic coastal waters influenced by glacial melt water and sea ice, Tellus B, 63, 815-822, https://doi.org/10.1111/j.16000889.2011.00540.x, 2011.

Sejr, M. K., Stedmon, C. A., Bendtsen, J., Abermann, J., JuulPedersen, T., Mortensen, J., and Rysgaard, S.: Evidence of local and regional freshening of Northeast Greenland coastal waters, Sci. Rep., 7, 13183, https://doi.org/10.1038/s41598-017-106109, 2017.

Shaffer, G. and Lambert, F.: In and out of glacial extremes by way of dust-climate feedbacks, P. Natl. Acad. Sci. USA, 115, 20262031, https://doi.org/10.1073/pnas.1708174115, 2018.

Sholkovitz, E. R., Boyle, E. A., and Price, N. B.: The removal of dissolved humic acids and iron during estuarine mixing, Earth Planet. Sci. Lett., 40, 130-136, https://doi.org/10.1016/0012821X(78)90082-1, 1978.

Slater, D. A., Straneo, F., Das, S. B., Richards, C. G., Wagner, T. J. W., and Nienow, P. W.: Localized Plumes Drive Front-Wide Ocean Melting of A Greenlandic Tidewater Glacier, Geophys. Res. Lett., 45, 12312-350358, https://doi.org/10.1029/2018GL080763, 2018.

Smith, R. W., Bianchi, T. S., Allison, M., Savage, C., and Galy, V.: High rates of organic carbon burial in fjord sediments globally, Nat. Geosci., 8, 450-453, https://doi.org/10.1038/ngeo2421, 2015.

Smoła, Z. T., Tatarek, A., Wiktor, J. M., Wiktor, J. M. W., Kubiszyn, A., and Węsławski, J. M.: Primary producers and production in Hornsund and Kongsfjorden - comparison of two fjord systems, 
Polish Polar Res., 38, 351-373, https://doi.org/10.1515/popore2017-0013, 2017.

Sommaruga, R.: When glaciers and ice sheets melt: consequences for planktonic organisms, J. Plankton Res., 37, 509-518, https://doi.org/10.1093/plankt/fbv027, 2015.

Spall, M. A., Jackson, R. H., and Straneo, F.: Katabatic WindDriven Exchange in Fjords, J. Geophys. Res.-Ocean., 122, 82468262, https://doi.org/10.1002/2017JC013026, 2017.

Statham, P. J., Skidmore, M., and Tranter, M.: Inputs of glacially derived dissolved and colloidal iron to the coastal ocean and implications for primary productivity, Global Biogeochem. Cy., 22, Gb3013, https://doi.org/10.1029/2007gb003106, 2008.

Stevens, L. A., Straneo, F., Das, S. B., Plueddemann, A. J., Kukulya, A. L., and Morlighem, M.: Linking glacially modified waters to catchment-scale subglacial discharge using autonomous underwater vehicle observations, The Cryosphere, 10, 417-432, https://doi.org/10.5194/tc-10-417-2016, 2016.

Stevenson, E. I., Fantle, M. S., Das, S. B., Williams, H. M., and Aciego, S. M.: The iron isotopic composition of subglacial streams draining the Greenland ice sheet, Geochim. Cosmochim. Acta, 213, 237-254, https://doi.org/10.1016/j.gca.2017.06.002, 2017.

Stibal, M., Anesio, A. M., Blues, C. J. D., and Tranter, M.: Phosphatase activity and organic phosphorus turnover on a high Arctic glacier, Biogeosciences, 6, 913-922, https://doi.org/10.5194/bg-6-913-2009, 2009.

St-Laurent, P., Yager, P. L., Sherrell, R. M., Stammerjohn, S. E., and Dinniman, M. S.: Pathways and supply of dissolved iron in the Amundsen Sea (Antarctica), J. Geophys. Res.-Ocean., 122, 7135-7162, https://doi.org/10.1002/2017JC013162, 2017.

St-Laurent, P., Yager, P. L., Sherrell, R. M., Oliver, H., Dinniman, M. S., and Stammerjohn, S. E.: Modeling the Seasonal Cycle of Iron and Carbon Fluxes in the Amundsen Sea Polynya, Antarctica, J. Geophys. Res.-Ocean., 124, 1544-1565, https://doi.org/10.1029/2018JC014773, 2019.

Stocker, T. F., Qin, D., Plattner, G.-K., Tignor, M., Allen, S. K., Boschung, J., Nauels, A., Xia, Y., Bex, V., and Midgley, P. M.: Climate change 2013: The physical science basis, Contribution of working group I to the fifth assessment report of the intergovernmental panel on climate change 1535, 2013.

Stoecker, D. K. and Lavrentyev, P. J.: Mixotrophic Plankton in the Polar Seas: A Pan-Arctic Review, Front. Mar. Sci., 5, 292, https://doi.org/10.3389/fmars.2018.00292, 2018.

Stoecker, D. K., Hansen, P. J., Caron, D. A., and Mitra, A.: Mixotrophy in the Marine Plankton, Annu. Rev. Mar. Sci., 9, 311-335, https://doi.org/10.1146/annurev-marine-010816-060617, 2017.

Straneo, F. and Cenedese, C.: The Dynamics of Greenland's Glacial Fjords and Their Role in Climate, Annu. Rev. Mar. Sci., 7, 89-112, https://doi.org/10.1146/annurev-marine-010213135133, 2015.

Straneo, F., Hamilton, G. S., Sutherland, D. A., Stearns, L. A., Davidson, F., Hammill, M. O., Stenson, G. B., and RosingAsvid, A.: Rapid circulation of warm subtropical waters in a major glacial fjord in East Greenland, Nat. Geosci., 3, 182-186, https://doi.org/10.1038/ngeo764, 2010.

Straneo, F., Curry, R. G., Sutherland, D. A., Hamilton, G. S., Cenedese, C., Våge, K., and Stearns, L. A.: Impact of fjord dynamics and glacial runoff on the circulation near Helheim Glacier, Nat. Geosci., 4, 322-327, 2011.
Straneo, F., Sutherland, D. A., Holland, D., Gladish, C., Hamilton, G. S., Johnson, H. L., Rignot, E., Xu, Y., and Koppes, M.: Characteristics of ocean waters reaching Greenland's glaciers, Ann. Glaciol., 53, 202-210, https://doi.org/10.3189/2012AoG60A059, 2012.

Straneo, F., Sutherland, D. A., Stearns, L., Catania, G., Heimbach, P., Moon, T., Cape, M. R., Laidre, K. L., Barber, D., Rysgaard, S., Mottram, R., Olsen, S., Hopwood, M. J., and Meire, L.: The Case for a Sustained Greenland Ice SheetOcean Observing System (GrIOOS), Front. Mar. Sci., 6, 138, https://doi.org/10.3389/fmars.2019.00138, 2019.

Štrojsová, A., Vrba, J., Nedoma, J., and Šimek, K.: Extracellular phosphatase activity of freshwater phytoplankton exposed to different in situ phosphorus concentrations, Mar. Freshw. Res., 56, 417-424, https://doi.org/10.1071/MF04283, 2005.

Strzepek, R. F., Maldonado, M. T., Higgins, J. L., Hall, J., Safi, K., Wilhelm, S. W., and Boyd, P. W.: Spinning the "Ferrous Wheel": The importance of the microbial community in an iron budget during the FeCycle experiment, Global Biogeochem. Cy., 19, GB4S26, https://doi.org/10.1029/2005GB002490, 2005.

Sundfjord, A., Albretsen, J., Kasajima, Y., Skogseth, R., Kohler, J., Nuth, C., Skarðhamar, J., Cottier, F., Nilsen, F., Asplin, L., Gerland, S., and Torsvik, T.: Effects of glacier runoff and wind on surface layer dynamics and Atlantic Water exchange in Kongsfjorden, Svalbard; a model study, Estuar. Coast. Shelf Sci., 187 260-272, https://doi.org/10.1016/j.ecss.2017.01.015, 2017.

Sutherland, D. A., Pickart, R. S., Peter Jones, E., Azetsu-Scott, K., Jane Eert, A., and Ólafsson, J.: Freshwater composition of the waters off southeast Greenland and their link to the Arctic Ocean, J. Geophys. Res.-Ocean., 114, C05020, https://doi.org/10.1029/2008JC004808, 2009.

Sutherland, D. A., Roth, G. E., Hamilton, G. S., Mernild, S. H., Stearns, L. A., and Straneo, F.: Quantifying flow regimes in a Greenland glacial fjord using iceberg drifters, Geophys. Res. Lett., 41, 8411-8420, https://doi.org/10.1002/2014GL062256, 2014.

Svendsen, H., Beszczynska-Møller, A., Hagen, J. O., Lefauconnier, B., Tverberg, V., Gerland, S., Ørbøk, J. B., Bischof, K., Papucci, C., Zajaczkowski, M., Azzolini, R., Bruland, O., Wiencke, C., Winther, J.-G., and Dallmann, W.: The physical environment of Kongsfjorden-Krossfjorden, an Arctic fjord system in Svalbard, Polar Res., 21, 133-166, https://doi.org/10.1111/j.17518369.2002.tb00072.x, 2002.

Tagliabue, A., Aumont, O., DeAth, R., Dunne, J. P., Dutkiewicz, S., Galbraith, E., Misumi, K., Moore, J. K., Ridgwell, A., Sherman, E., Stock, C., Vichi, M., Völker, C., and Yool, A.: How well do global ocean biogeochemistry models simulate dissolved iron distributions?, Global Biogeochem. Cy., 30, 149174, https://doi.org/10.1002/2015GB005289, 2016.

Taylor, R. L., Semeniuk, D. M., Payne, C. D., Zhou, J., Tremblay, J.-É., Cullen, J. T., and Maldonado, M. T.: Colimitation by light, nitrate, and iron in the Beaufort Sea in late summer, J. Geophys. Res.-Ocean., 118, 3260-3277, https://doi.org/10.1002/jgrc.20244, 2013.

Thingstad, T. F., Bellerby, R. G. J., Bratbak, G., Børsheim, K. Y., Egge, J. K., Heldal, M., Larsen, A., Neill, C., Nejstgaard, J., Norland, S., Sandaa, R.-A., Skjoldal, E. F., Tanaka, T., Thyrhaug, R., and Töpper, B.: Counterintuitive carbon-to-nutrient cou- 
pling in an Arctic pelagic ecosystem, Nature, 455, 387-390, https://doi.org/10.1038/nature07235, 2008.

Thuroczy, C.-E., Alderkamp, A.-C., Laan, P., Gerringa, L. J. A., Mills, M. M., Van Dijken, G. L., De Baar, H. J. W., and Arrigo, K. R.: Key role of organic complexation of iron in sustaining phytoplankton blooms in the Pine Island and Amundsen Polynyas (Southern Ocean), Deep. Res. Part Ii, 71-76, 49-60, https://doi.org/10.1016/j.dsr2.2012.03.009, 2012.

Tonnard, M., Planquette, H., Bowie, A. R., van der Merwe, P., Gallinari, M., Desprez de Gésincourt, F., Germain, Y., Gourain, A., Benetti, M., Reverdin, G., Tréguer, P., Boutorh, J., Cheize, M., Lacan, F., Menzel Barraqueta, J.-L., Pereira-Contreira, L., Shelley, R., Lherminier, P., and Sarthou, G.: Dissolved iron in the North Atlantic Ocean and Labrador Sea along the GEOVIDE section (GEOTRACES section GA01), Biogeosciences, 17, 917943, https://doi.org/10.5194/bg-17-917-2020, 2020.

Torres, M. A., Moosdorf, N., Hartmann, J., Adkins, J. F., and West, A. J.: Glaciers, sulfide oxidation, and the carbon cycle, P. Natl. Acad. Sci. USA, 114, 8716-8721, https://doi.org/10.1073/pnas.1702953114, 2017.

Torsvik, T., Albretsen, J., Sundfjord, A., Kohler, J., Sandvik, A. D., Skarðhamar, J., Lindbäck, K., and Everett, A.: Impact of tidewater glacier retreat on the fjord system: Modeling present and future circulation in Kongsfjorden, Svalbard, Estuar. Coast. Shelf Sci., 220, 152-165, https://doi.org/10.1016/j.ecss.2019.02.005, 2019.

Tranter, M., Huybrechts, P., Munhoven, G., Sharp, M. J., Brown, G. H., Jones, I.W., Hodson, A. J., Hodgkins, R., and Wadham, J. L.: Direct effect of ice sheets on terrestrial bicarbonate, sulphate and base cation fluxes during the last glacial cycle: minimal impact on atmospheric $\mathrm{CO}_{2}$ concentrations, Chem. Geol., 190, 33-44, https://doi.org/10.1016/S0009-2541(02)00109-2, 2002.

Tremblay, J.-É., Anderson, L. G., Matrai, P., Coupel, P., Bélanger, S., Michel, C., and Reigstad, M.: Global and regional drivers of nutrient supply, primary production and $\mathrm{CO}_{2}$ drawdown in the changing Arctic Ocean, Prog. Oceanogr., 193, 171-196, https://doi.org/10.1016/j.pocean.2015.08.009, 2015.

Turk, D., Bedard, J. M., Burt, W. J., Vagle, S., Thomas, H., AzetsuScott, K., McGillis, W. R., Iverson, S. J., and Wallace, D. W. R.: Inorganic carbon in a high latitude estuary-fjord system in Canada's eastern Arctic, Estuar. Coast. Shelf Sci., 178, 137-147, https://doi.org/10.1016/j.ecss.2016.06.006, 2016.

Twining, B. S. and Baines, S. B.: The Trace Metal Composition of Marine Phytoplankton, Ann. Rev. Mar. Sci., 5, 191-215, https://doi.org/10.1146/annurev-marine-121211-172322, 2013.

Uehlinger, U., Robinson, C., Hieber, M., and Zah, R.: The physicochemical habitat template for periphyton in alpine glacial streams under a changing climate, Hydrobiologia, 657, 107-121, 10.1007/s10750-009-9963-x, 2010.

Uitz, J., Claustre, H., Griffiths, F. B., Ras, J., Garcia, N., and Sandroni, V.: A phytoplankton class-specific primary production model applied to the Kerguelen Islands region (Southern Ocean), Deep Sea Res. Part I, 56, 541-560, https://doi.org/10.1016/j.dsr.2008.11.006, 2009.

van de Poll, W. H., Kulk, G., Rozema, P. D., Brussaard, C. P. D., Visser, R. J. W., and Buma, A. G. J.: Contrasting glacial meltwater effects on post-bloom phytoplankton on temporal and spatial scales in Kongsfjorden, Spitsbergen, Elem. Sci. Anth., 6, 50, https://doi.org/10.1525/elementa.307, 2018. van der Merwe, P. C., Wuttig, K., Holmes, T., Trull, T., Chase, Z., Townsend, A., Goemann, K., and Bowie, A. R.: High lability $\mathrm{Fe}$ particles sourced from glacial erosion can meet previously unaccounted biological demand: Heard Island, Southern Ocean, Front. Mar. Sci., 6, 332, https://doi.org/10.3389/fmars.2019.00332, 2019.

Vandersea, M. W., Kibler, S. R., Tester, P. A., Holderied, K., Hondolero, D. E., Powell, K., Baird, S., Doroff, A., Dugan, D., and Litaker, R. W.: Environmental factors influencing the distribution and abundance of Alexandrium catenella in Kachemak bay and lower cook inlet, Alaska, Harmful Algae, 77, 81-92, https://doi.org/10.1016/j.hal.2018.06.008, 2018.

Vergara-Jara, M. J., DeGrandpre, M. D., Torres, R., Beatty, C. M., Cuevas, L. A., Alarcón, E., and Iriarte, J. L.: Seasonal changes in carbonate saturation state and air-sea $\mathrm{CO}_{2}$ fluxes during an annual cycle in a stratified-temperate fjord (Reloncaví Fjord, Chilean Patagonia), J. Geophys. Res.-Biogeosci., 124, 28512865, https://doi.org/10.1029/2019JG005028, 2019.

Vraspir, J. M. and Butler, A.: Chemistry of Marine Ligands and Siderophores, Annu. Rev. Mar. Sci., 1, 43-63, https://doi.org/10.1146/annurev.marine.010908.163712, 2009.

Wadham, J. L., Tranter, M., Skidmore, M., Hodson, A. J., Priscu, J., Lyons, W. B., Sharp, M., Wynn, P., and Jackson, M.: Biogeochemical weathering under ice: Size matters, Global Biogeochem. Cy., 24, GB3025, https://doi.org/10.1029/2009GB003688, 2010.

Wadham, J. L., Hawkings, J., Telling, J., Chandler, D., Alcock, J., O’Donnell, E., Kaur, P., Bagshaw, E., Tranter, M., Tedstone, A., and Nienow, P.: Sources, cycling and export of nitrogen on the Greenland Ice Sheet, Biogeosciences, 13, 6339-6352, https://doi.org/10.5194/bg-13-6339-2016, 2016.

Wadham, J. L., Hawkings, J. R., Tarasov, L., Gregoire, L. J., Spencer, R. G. M., Gutjahr, M., Ridgwell, A., and Kohfeld, K. E.: Ice sheets matter for the global carbon cycle, Nat. Commun., 10, 3567, https://doi.org/10.1038/s41467-019-11394-4, 2019.

Ward, B. A. and Follows, M. J.: Marine mixotrophy increases trophic transfer efficiency, mean organism size, and vertical carbon flux, P. Natl. Acad. Sci. USA, 113, 2958-2963, https://doi.org/10.1073/pnas.1517118113, 2016.

Wçslawski W, J. M. and Legezytńska, J.: Glaciers caused zooplankton mortality?, J. Plankton Res., 20, 1233-1240, https://doi.org/10.1093/plankt/20.7.1233, 1998.

Wehrmann, L. M., Formolo, M. J., Owens, J. D., Raiswell, R., Ferdelman, T. G., Riedinger, N., and Lyons, T. W.: Iron and manganese speciation and cycling in glacially influenced high-latitude fjord sediments (West Spitsbergen, Svalbard): Evidence for a benthic recycling-transport mechanism, Geochim. Cosmochim. Acta, 141, 628-655, https://doi.org/10.1016/j.gca.2014.06.007, 2014.

Wells, M. L., Trainer, V. L., Smayda, T. J., Karlson, B. S. O., Trick, C. G., Kudela, R. M., Ishikawa, A., Bernard, S., Wulff, A., Anderson, D. M., and Cochlan, W. P.: Harmful algal blooms and climate change: Learning from the past and present to forecast the future, Harmful Algae, 49, 68-93, https://doi.org/10.1016/j.hal.2015.07.009, 2015.

White, J. R. and Dagg, M. J.: Effects of suspended sediments on egg production of the calanoid copepod Acartia tonsa, Mar. Biol., 102, 315-319, https://doi.org/10.1007/BF00428483, 1989. 
Wiedmann, I., Reigstad, M., Marquardt, M., Vader, A., and Gabrielsen, T. M.: Seasonality of vertical flux and sinking particle characteristics in an ice-free high arctic fjord-Different from subarctic fjords?, J. Mar. Syst., 154, 192-205, https://doi.org/10.1016/j.jmarsys.2015.10.003, 2016.

Windom, H., Byrd, J., Smith, R., Hungspreugs, M., Dharmvanij, S., Thumtrakul, W., and Yeats, P.: Trace metalnutrient relationships in estuaries, Mar. Chem., 32, 177-194, https://doi.org/10.1016/0304-4203(91)90037-W, 1991.

Włodarska-Kowalczuk, M. and Pearson, T. H.: Soft-bottom macrobenthic faunal associations and factors affecting species distributions in an Arctic glacial fjord (Kongsfjord, Spitsbergen), Polar Biol., 27, 155-167, https://doi.org/10.1007/s00300-0030568-y, 2004.

Włodarska-Kowalczuk, M. and Weslawski, J. M.: Impact of climate warming on Arctic benthic biodiversity: a case study of two Arctic glacial bays, Clim. Res., 18, 127-132, 2001.

Włodarska-Kowalczuk, M., Pearson, T. H., and Kendall, M. A.: Benthic response to chronic natural physical disturbance by glacial sedimentation in an Arctic fjord, Mar. Ecol. Progr. Ser., 303, 31-41, https://doi.org/10.3354/meps303031, 2005.

Włodarska-Kowalczuk, M., Mazurkiewicz, M., Górska, B., Michel, L. N., Jankowska, E., and Zaborska, A.: Organic carbon origin, benthic faunal consumption and burial in sediments of northern Atlantic and Arctic fjords (60$\left.81^{\circ} \mathrm{N}\right)$, J. Geophys. Res.-Biogeosci., 124, 3737-3751, https://doi.org/10.1029/2019JG005140, 2019

Wojtasiewicz, B., Trull, T. W., Clementson, L., Davies, D. M., Patten, N. L., Schallenberg, C., and Hardman-Mountford, N. J.: Factors Controlling the Lack of Phytoplankton Biomass in Naturally Iron Fertilized Waters Near Heard and McDonald Islands in the Southern Ocean, Front. Mar. Sci., 6, 531, https://doi.org/10.3389/fmars.2019.00531, 2019.
Xie, H., Bélanger, S., Song, G., Benner, R., Taalba, A., Blais, M., Tremblay, J.-É., and Babin, M.: Photoproduction of ammonium in the southeastern Beaufort Sea and its biogeochemical implications, Biogeosciences, 9, 3047-3061, https://doi.org/10.5194/bg9-3047-2012, 2012.

$\mathrm{Xu}$, Y., Rignot, E., Menemenlis, D., and Koppes, M.: Numerical experiments on subaqueous melting of greenland tidewater glaciers in response to ocean warming and enhanced subglacial discharge, Ann. Glaciol., 53, 229-234, https://doi.org/10.3189/2012AoG60A139, 2012.

Yde, J. C., Knudsen, N. T., and Nielsen, O. B.: Glacier hydrochemistry, solute provenance, and chemical denudation at a surge-type glacier in Kuannersuit Kuussuat, Disko Island, West Greenland, J. Hydrol., 300, 172-187, https://doi.org/10.1016/j.jhydrol.2004.06.008, 2005.

Yde, J. C., Knudsen, N. T., Hasholt, B., and Mikkelsen, A. B.: Meltwater chemistry and solute export from a Greenland Ice Sheet catchment, Watson River, West Greenland, J. Hydrol., 519, 2165-2179, https://doi.org/10.1016/j.jhydrol.2014.10.018, 2014.

Zajączkowski, M. and Włodarska-Kowalczuk, M.: Dynamic sedimentary environments of an Arctic glacier-fed river estuary (Adventfjorden, Svalbard). I. Flux, deposition, and sediment dynamics, Estuar. Coast. Shelf Sci., 74, 285-296, https://doi.org/10.1016/j.ecss.2007.04.015, 2007.

Zhang, R., John, S. G., Zhang, J., Ren, J., Wu, Y., Zhu, Z., Liu, S., Zhu, X., Marsay, C. M., and Wenger, F.: Transport and reaction of iron and iron stable isotopes in glacial meltwaters on Svalbard near Kongsfjorden: From rivers to estuary to ocean, Earth Planet. Sci. Lett., 424, 201-211, https://doi.org/10.1016/j.epsl.2015.05.031, 2015. 